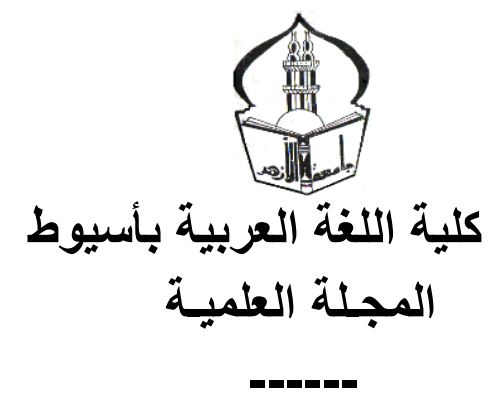

\title{
الألف المهمولة
}

في

حديث اللفويين

إعداد

د / معدد بن إبراهيم السيف

أستاذ مشارك في كلية اللغة العربية والدراسات الاجتماعية بجام الإية العربة

( العدد الرابع والثلاثون - الجزء الرابع ه 1 ـ rم )

عة القصيم 


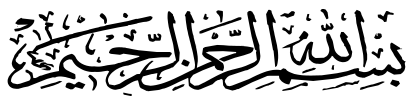

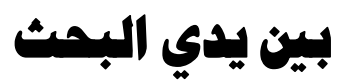

يرى اللغويون أن ألف المد صوت طارئ في البنية ، وأنها متغيرة لا تصمد أمام مقتضيات التغيير التي تستدعيها العوارض الطارئة على البنية ؛ من تثنية

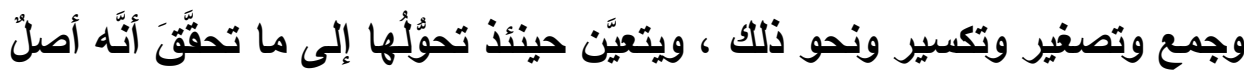

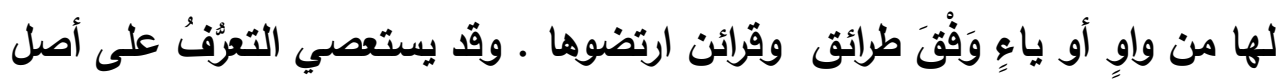

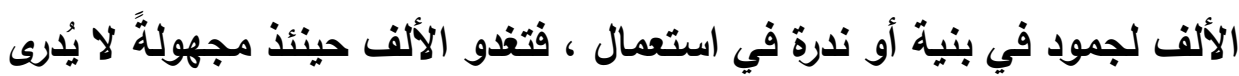
أصلها ومما نشأت ، وقد تتبه القدماء لذلك ، واصطلحوا على بعض المعاييز

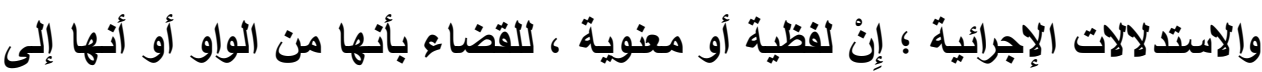
الياء أميل • وقد وجدت في معالجة اللغويين لهذه الظاهرة ما هو منثور ومخبوء في بطون المدونات اللغوية ، وهو جدير بالتتبع والتناول ، فجمعت منه ما تيسر لي ، وحررته في هذه الوريقات مصدًَّا بتمهيبٍ عرضت فيه على عجل لطبيعة الألف

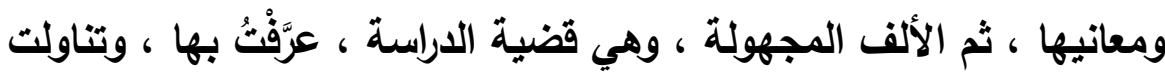
صنوفَها ؛ أصلية ، ومبدلة ، وزائدة ، وما قالوه في شأن معالجتها في ضوء ألوانها المختلفة . 
الألف، وهي حرف المد، أو مـا يسميها المحدثون بالقتحة الطويلةة(1)، وهي حرف هوائي يخرج من الجوف عند الخليل، قال: \. . . وأريعة أحرف جُوف وهي: الواو والياء والألف اللينة واللهزةة، وسميت جُوفا لأنها تخرج من الجوف فلا تقع في مدرجـة من مدارج اللسـان، ولا من مدارج العلق، ولا من مـدرج اللهاة، وإنمـا هي هاوية في الهواء، فلم يكن لها حيز تنسب إليه إلا الجوف هن (؟). وعند سييويه الألف حرف غير مهموس، أو حرف مد ولين، قال عنها وعن أختيها اليـاء والـواو: " هذه الحروف غير مهموسـات، وهـي حروف لين ومــ، ومخارجها متسعة لهواء الصوت، وليس شيء من الحروف أوسـع مخارج منها هـ ه

ومخرجها مسن أقصسى الحلق، قـال: 》. . ـ فللحلق منهـا ثلاثة، فأقصساها

مخرجًا الهمزة واللهاء والألف « (؛). والجمهور على ما قال (•).

$$
\begin{aligned}
& \text { ( (1) دراسات في علم اللغة ( كمال بشر ): V^. }
\end{aligned}
$$

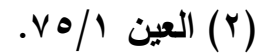

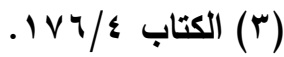

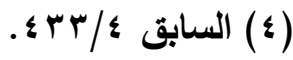

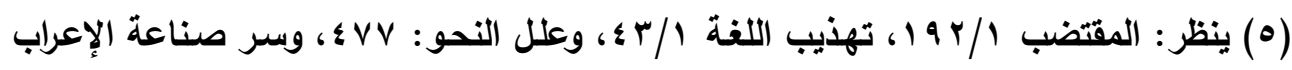

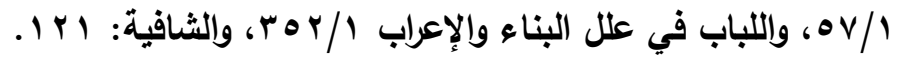


والمحدثون » ينسبون الألف إلى مكان ما في تجويف الفم « (').

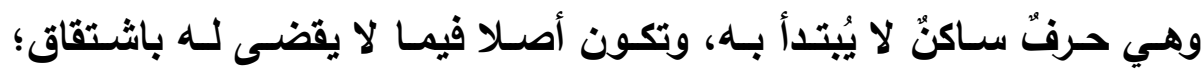
كالحروف، وأسماء الحروف، والأسماء المبنية، والأسماء الأعجمية، وأمـا الأسـاء المتمكنة والأفعال فلا تكون فيها إلا مبدلة أو زائدة، ولا تكون فيها أصـلا، وقد ثبت هذا استقراءً كما قال ابن جني(؟)، وفي توجيهه قال الرضي: \ أما في الثلاثي فلأن

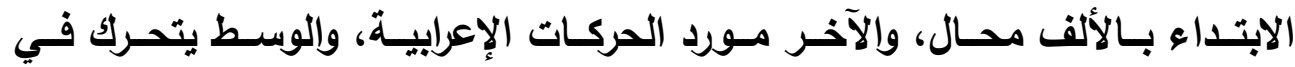
التصغير، فلم يمكن وضعها ألقًا. وأما في الرياعي فالأول والثاني والرابـع لمـا مرَّ في الثلاثي، والثالث لتحركهـ

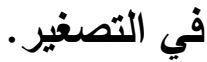
وأمـا في الخماسـي فـالأول والثاني والثالث لمـا مـرَّ في الثُلاثـي والربـاعي، والخامس لأنه مورد الإعراب، والرابع معتقب الإعراب في التصغير والتكسير.

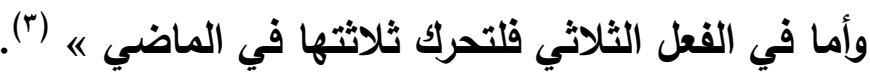
والألف بطبيعتها ضعيفة وإسعة المخرج لا تقبل التحريك، وإذا اضطروا إلى لى

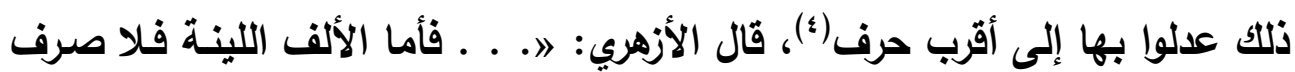
لها، إنما هي جرس مدة بعد فتحة، فإذا وقعت عليها صروف الحركات ضعفت عن احتمالها واستتامت إلى الههزة أو الياء أو الواو، كقولك: عِصَّابة وعَصَائب، وكَاهِل وكَوَا هِل، وسِِعْلَة وثْلاث سِعْلَيَات فيمن يجمع بالتاء، فالهمزة التي في العصـائب هي الألف التي في العصابة، والواو التي في الكواهل هي الألف التي في الكاهل جاءت

(1) (1) دراسة الصوت اللغوي: 0 ه ؟

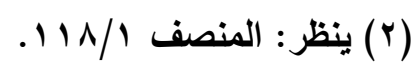

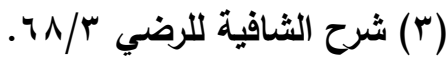

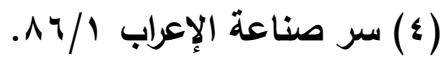


خلفا منها، والياء التي في السعليات خلف من الألف التي في السعلاة، ونحو ذلك

كثير، فالألف اللينة هي أضعف الحروف المعتلة هـ (1).

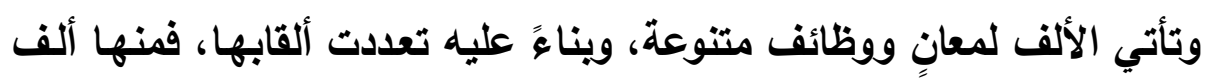

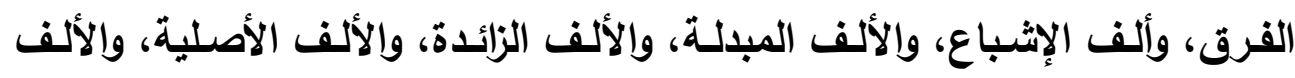

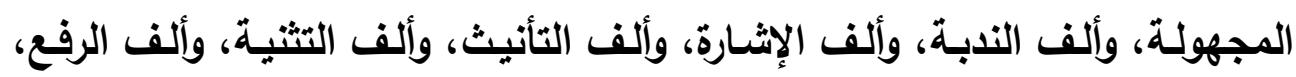
وألف الجمع، وغيرها (`).

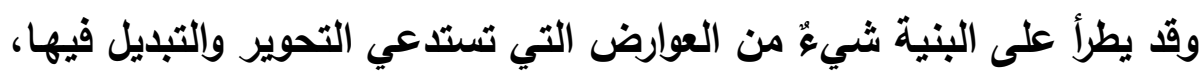

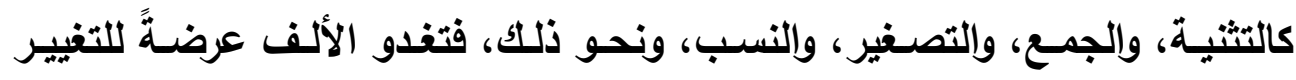
بسبب طُروء تحريكٍ استدعاه النظام العارض، فيتعين حينئذ عودتها إلى أصلها؛ والوًا

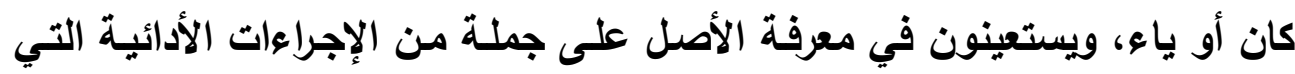

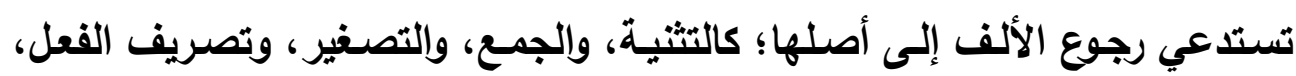
وإسناده إلى الضمائر، والإمالة، وغيرها (ان.

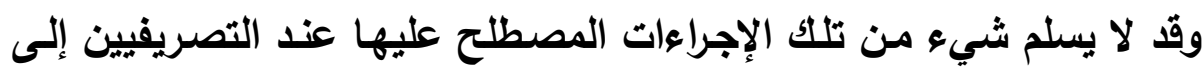

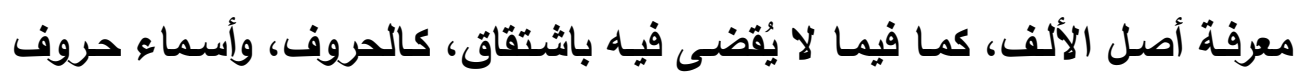

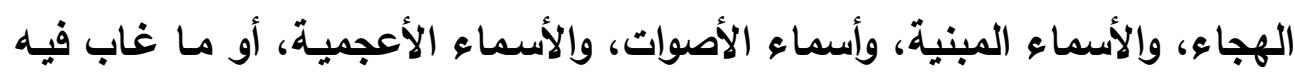

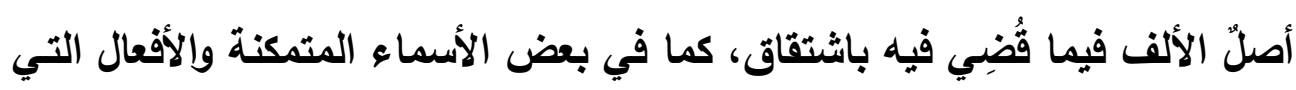

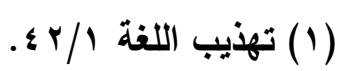

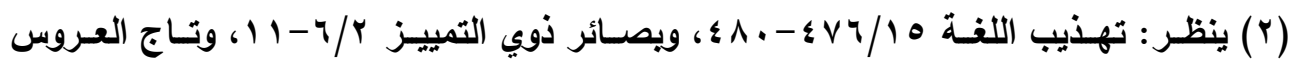
. $r 4 \Lambda-r+1 / \varepsilon$.

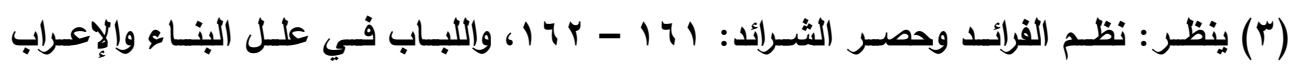
$. \varepsilon \wedge \Psi-\varepsilon \wedge r / r$ 
لم تبلغنا تصاريفها، فـلا يعرف أَمِن واوٍ هي أم من يـاء؟ وقد تثبَّه النحويون لأمر هذه الألف وناقشوها واصطلحوا لها بالألف المجهولة.

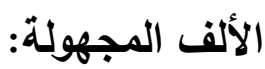

كذا جاء المصطلح عند الأزهري في التهذيب، وأُلْفف عند كثير من خالفيه،

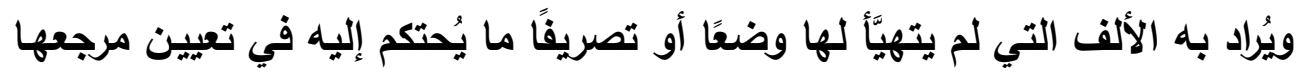

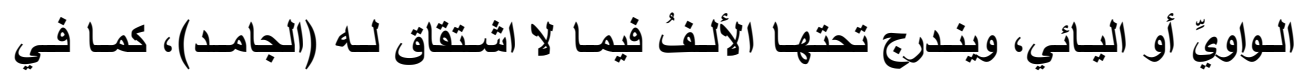

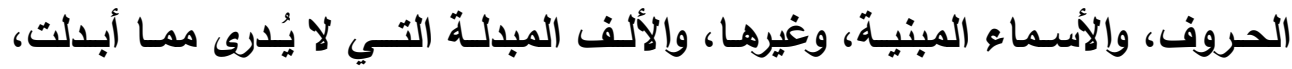

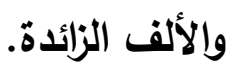

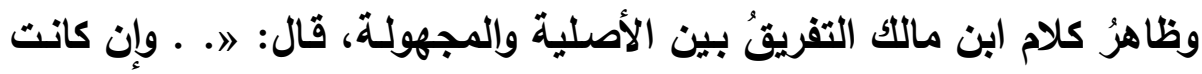

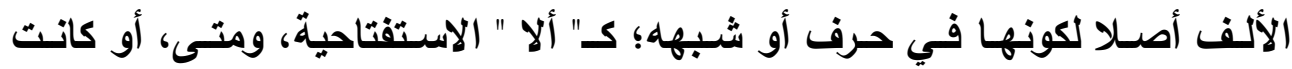

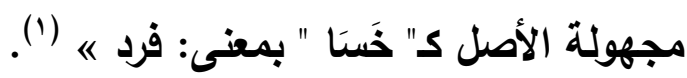

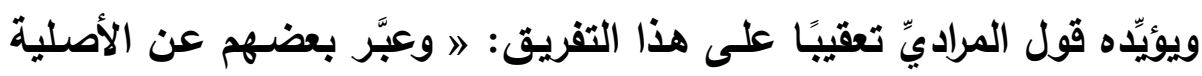

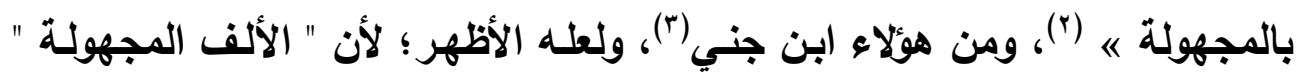

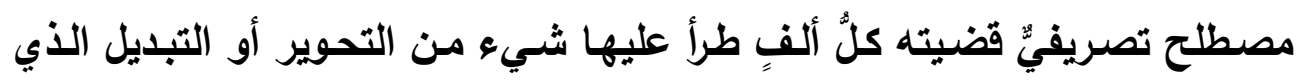

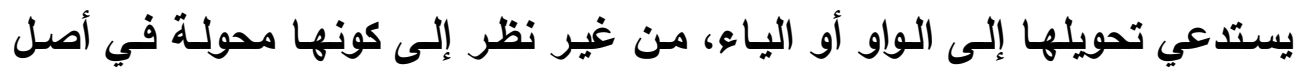

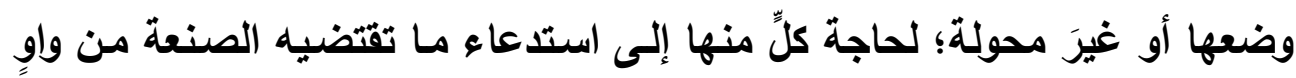

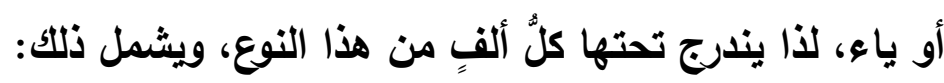

(1) - (1) شرح التسهيل

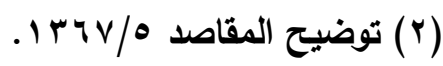

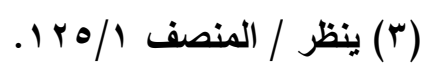




\section{أولا: الألف الأصلية}

وهـي الألف في كل مـا لا يصـح فيـه تصريف ولا اشتقاق، كـالحروف،

وأسماء حروف الهجاء، والأسماء المبنية، وأسماء الأصوات، والأسماء الأعجمية.

\section{ا- الصروف:}

والمعنيٌٌ منها ما كان مختومًا بالألف، سواء كان ثنائيًا وضعا أم ثُلاثيًا،

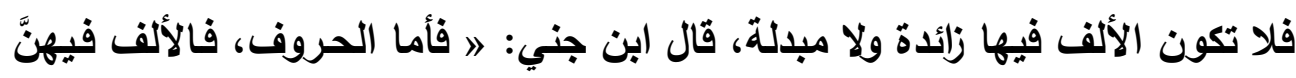

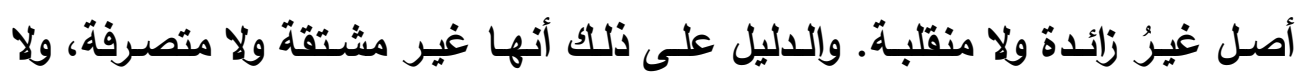

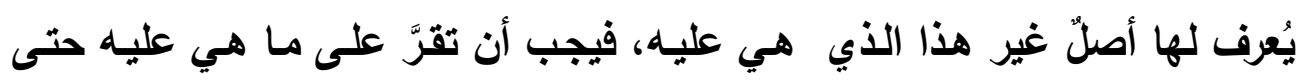
تقوم دلالة على أنها زائدة أو منقلبة.

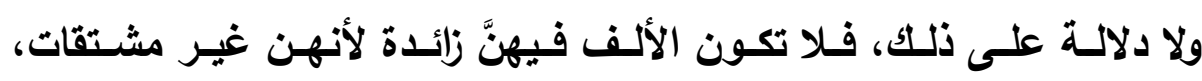

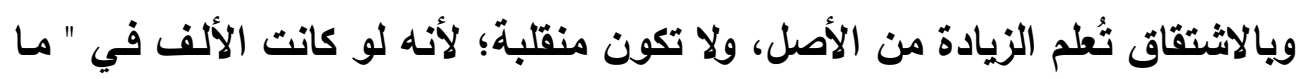

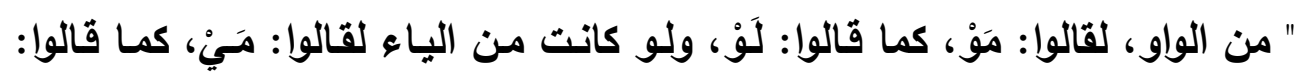

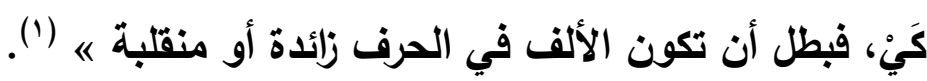

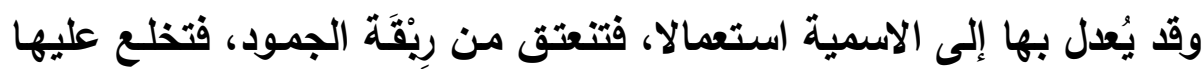

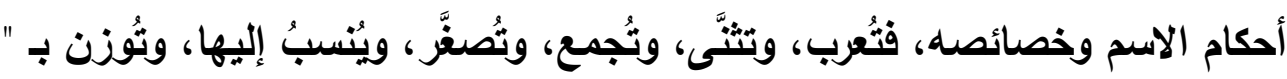

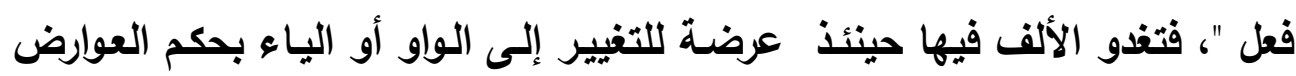

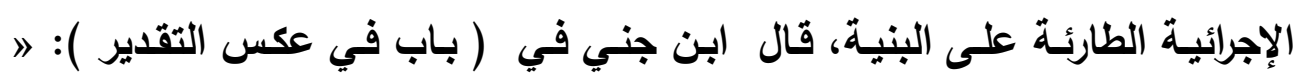

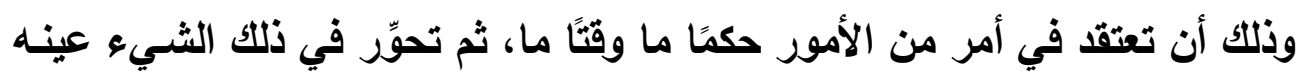

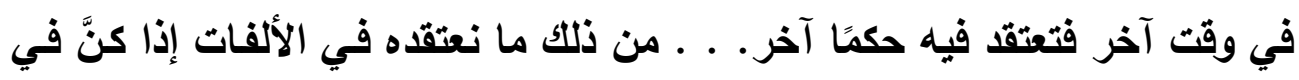

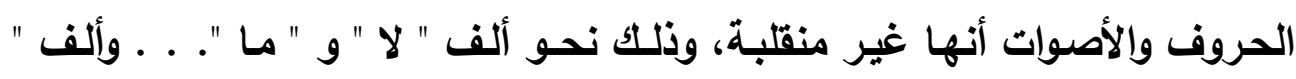

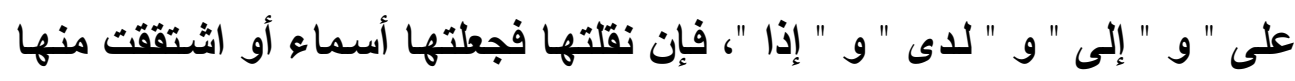

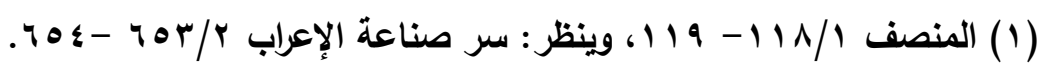


فعلا استحال ذلك التقدير، واعتقدت فيها ما تعتقده في المنقلب. وذلكك قولك: مَوَّيت،

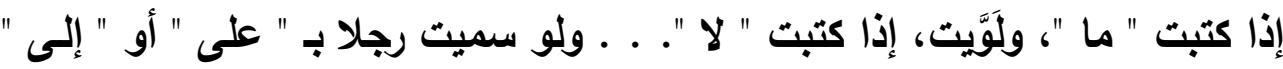

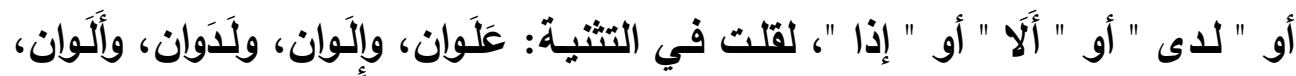

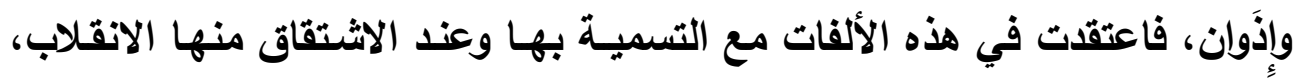

وقد كانت قبل ذلك عندك غير منقلبة ه ( ).

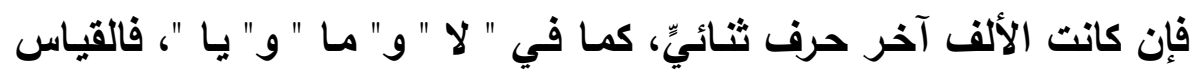

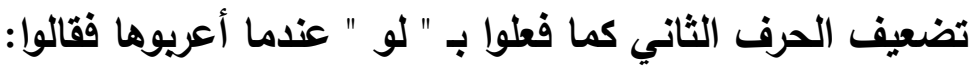

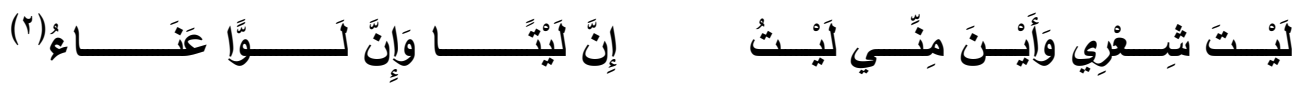
لأن الاسم لا يكون على أقل من ثلاثة أحرف، فإذا كرر الثاني تلتقي ألفان

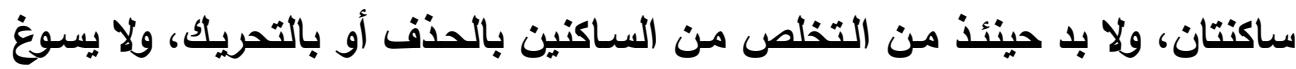

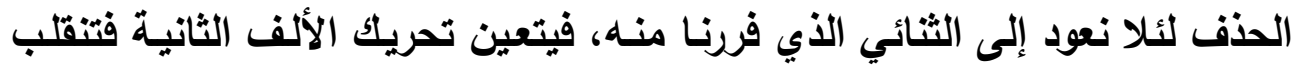
همزة، فيقال: لاء، وماء، وياء، وقد حكاه اللحياني عن الكسائي (َ).

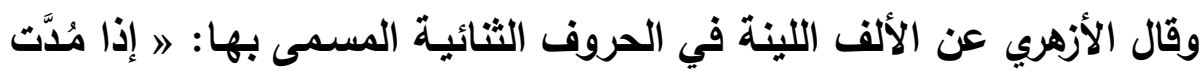

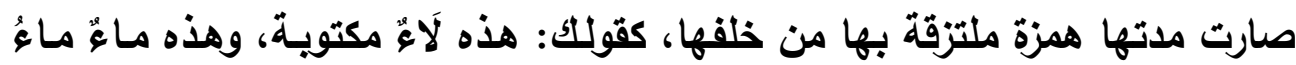
الصلة، لا ماءُ المجازاة، ونحو ذلك من الحروف المصوَّرة إذا وقعت مواقع الأسماء

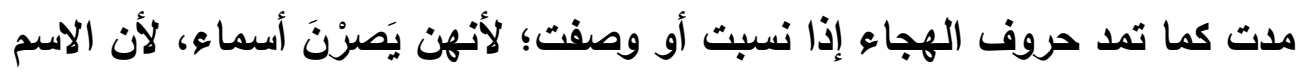

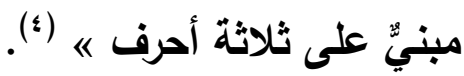

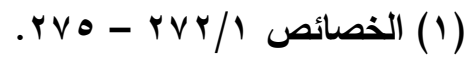

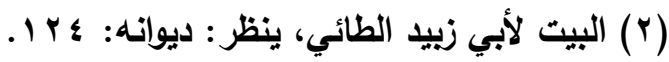

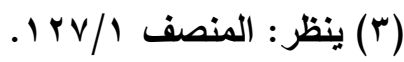

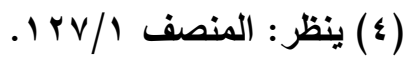


وأما ما كان أصله ثلاثبًا و وثالثه ألف من هذه الحروف ف " على، وإلى، ويلى،

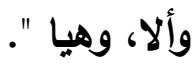

وفي تقديرهم لأصل الألفات في هذه الحروف بعد نقلها إلى الاسمية ركنوا إلى

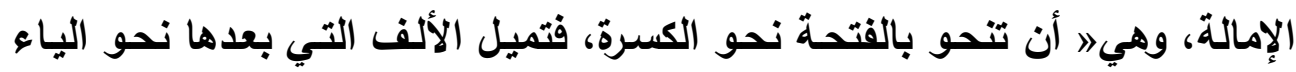

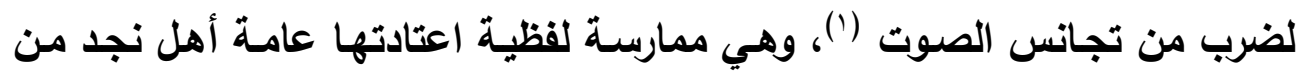
تميم وأسد وقيس(r)، وسماعها فيما كانت فيه ألف مجهولـة يشعر بأنها من الياء؛

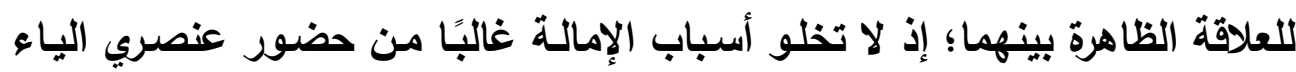

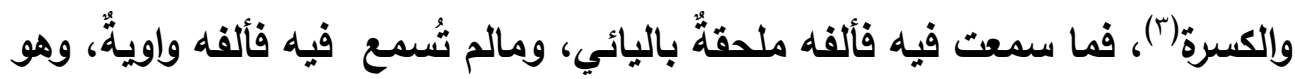

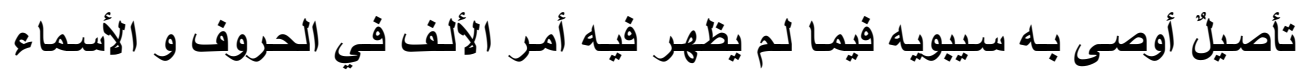

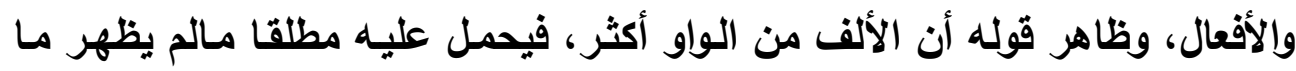

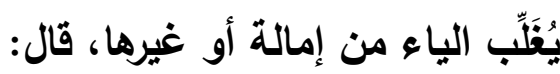

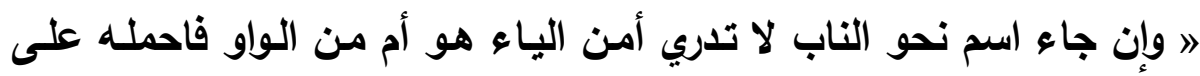

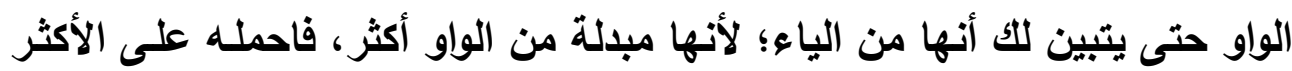
حتي يتبين لك « (๕). وقال: » فإذا جاء شيء من المنقوص ليس لله فعل تثبت فيه الواو، ولا لـه

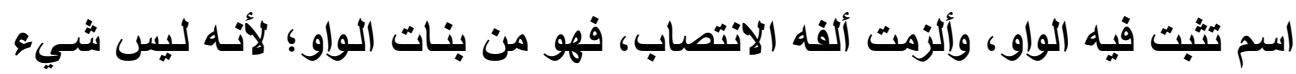

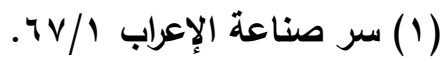

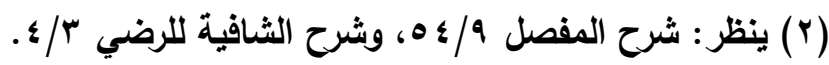

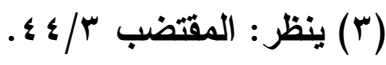

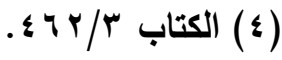


من بنات الياء يلزمه الانتصاب لا تجوز فيه الإمالة، إنما يكون ذلك في بنات الواو

ونقل عنه الجوهري قوله: " ألف " إلى " و" على " منقلبتان مـن واويـن؛ لأن

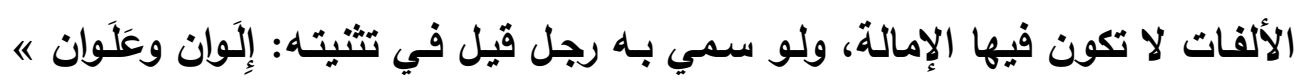

وهو ظاهر تطبيقه، فقد ثنَّى " على" و " وإلى " بالواو؛ لأن الإمالة لا تحسن

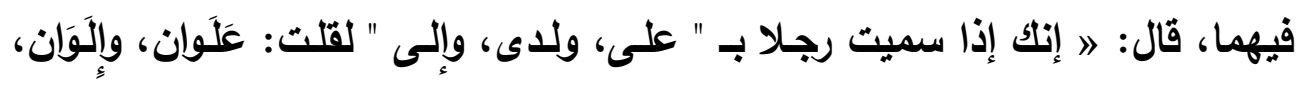

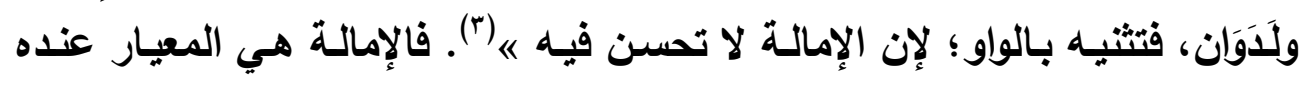

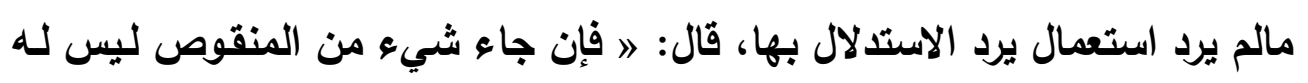

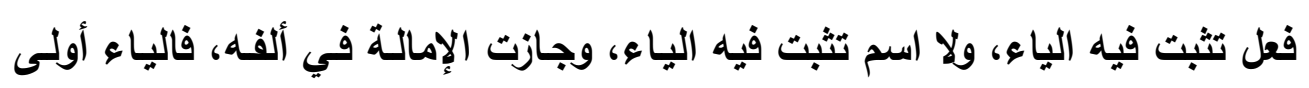

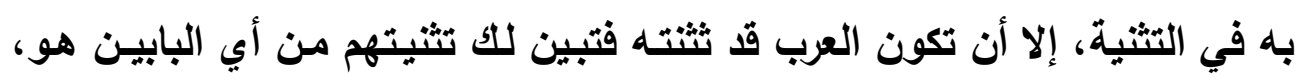

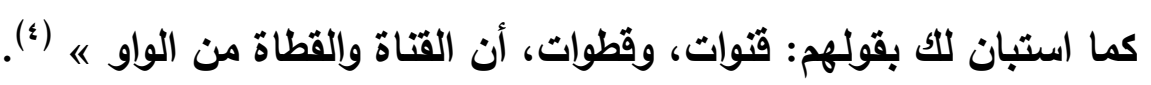

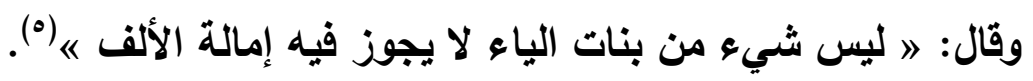

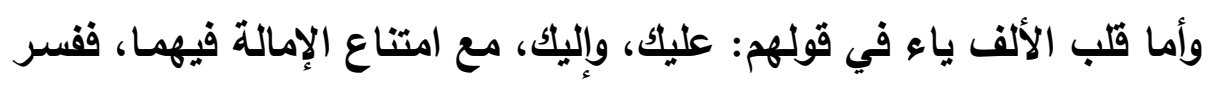

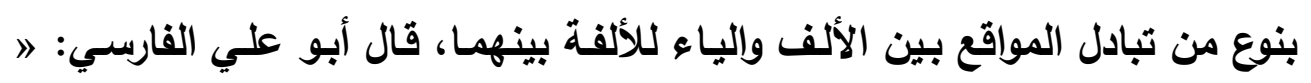

فإن قال قائل في: " عليه " و" لديه ".

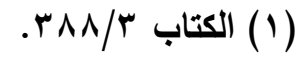

$$
\begin{aligned}
& \text { (Y) الصحاح Tr/T (Y) }
\end{aligned}
$$

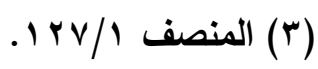

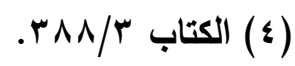

$$
\begin{aligned}
& \text { (•) السابق }
\end{aligned}
$$


ما بالهما قلبا ياعين لما اتصلا بالمضمر، والإمالة لا تجوز فيهما؟ وهلا لم

يقلبا ياعين ولكن واوين، كما أنكك لو سميت بهما لقلت: إِلَوان وعَلَوان؟

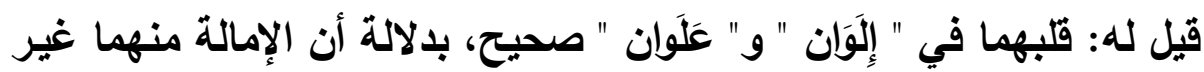

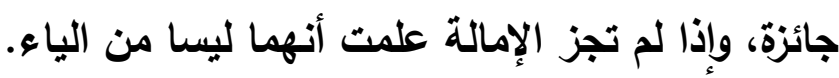

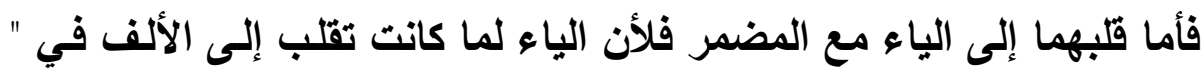

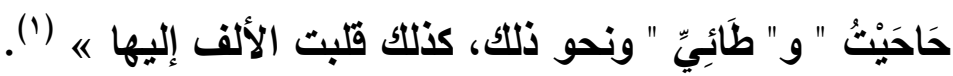

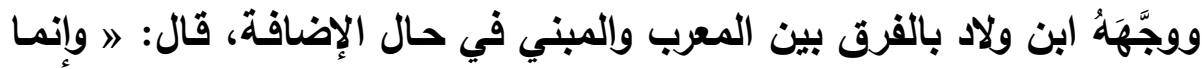

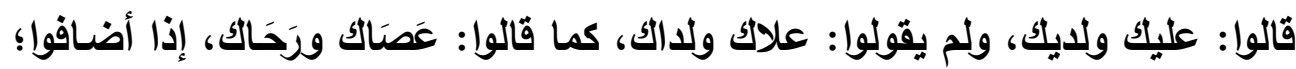

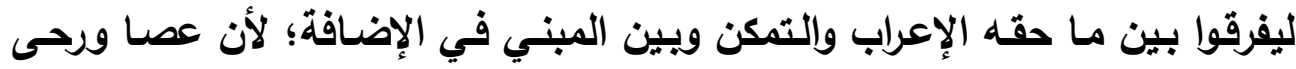

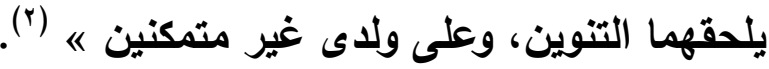

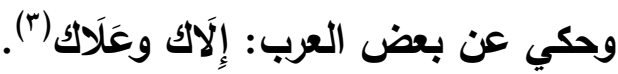

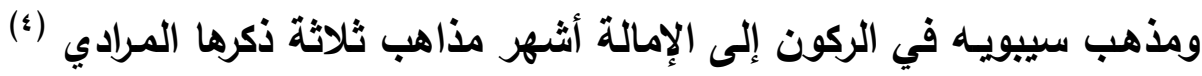

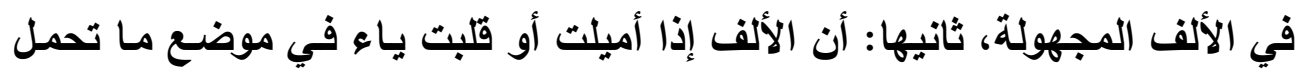

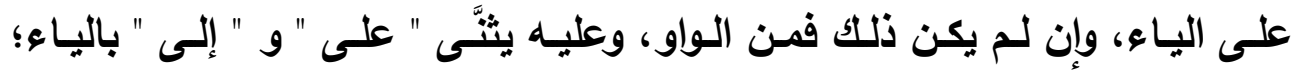

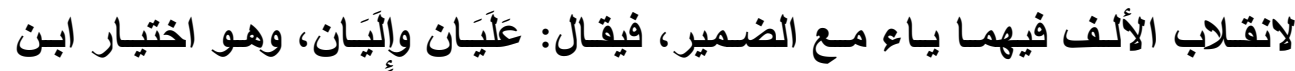

عصفور (0) وابن مالك (").

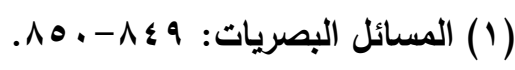

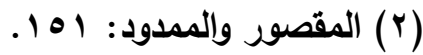

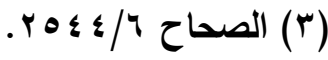

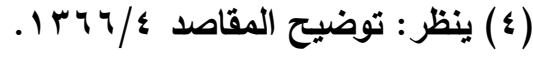

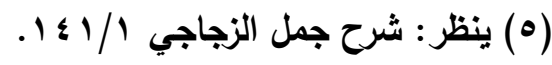

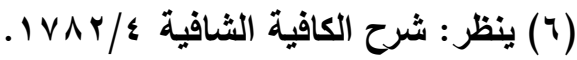


وجعله اليزديُّ القياس مالم يرد سماعٌ بقلبها واوًًا، قال: " إن سُمِيّي بـ " إلى "

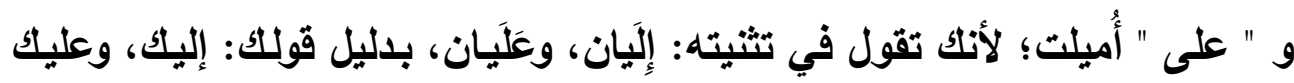

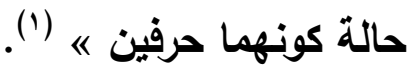

والثالث: قلب الألف ياء مطلقا، ولم يُعز (؟).

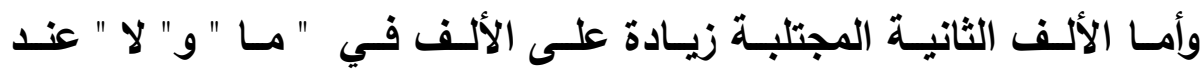

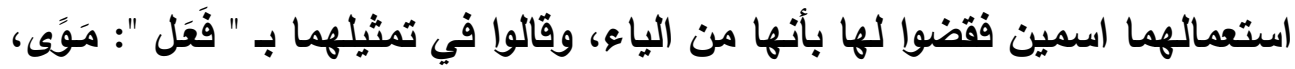

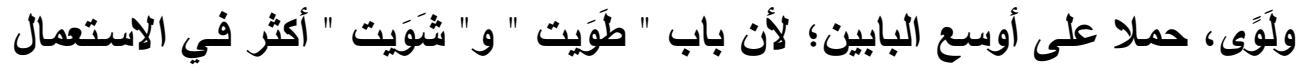

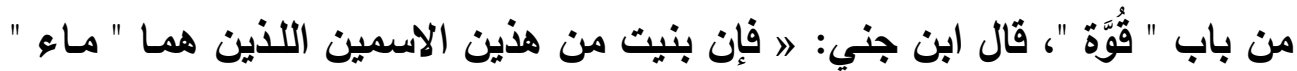

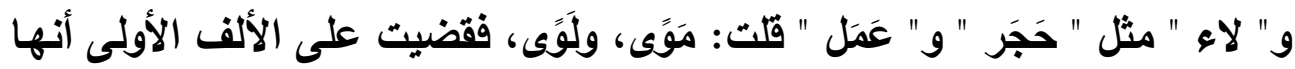

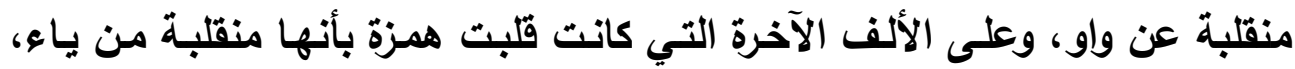
فخرجت اللفظتان إلى باب " شَوَيت " و " طَوَيت "، ولم تقضِ على الألى الألف الآخرة أنها من الواو كالألف الأولى من قبل أن العين قد ثبت أنها من واو، وإللام بعدها حرف

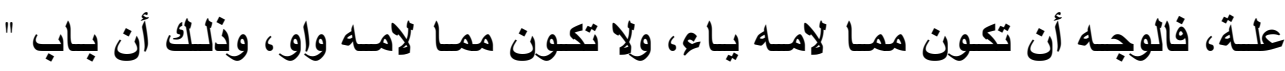

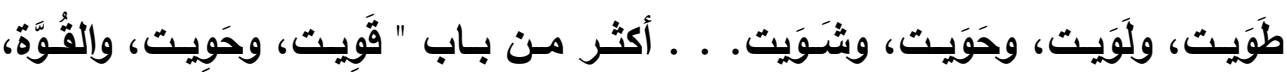

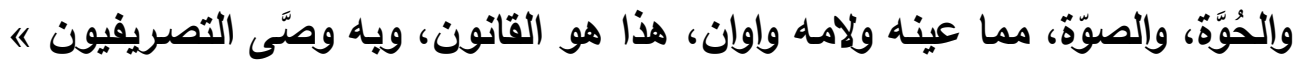

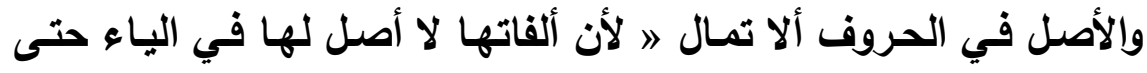

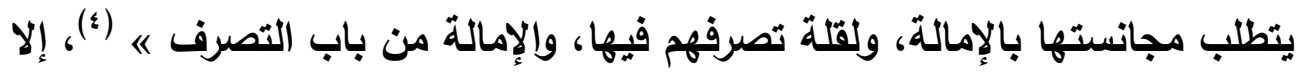

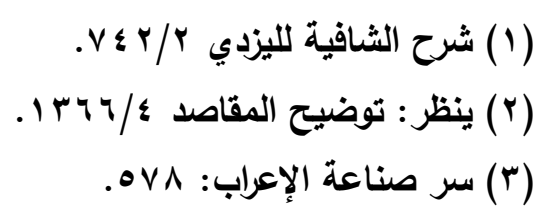

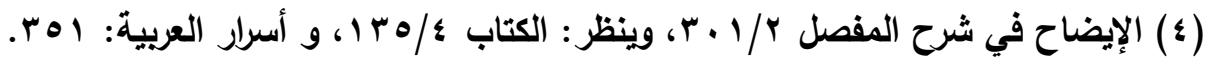




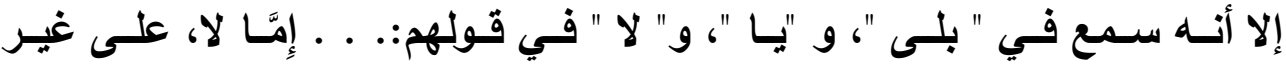
قياس(")، وشذَّذه الثاطبي (†)، ويسوَّغه شبهها بالأسماء القائمة بنفسها واستقلالها.

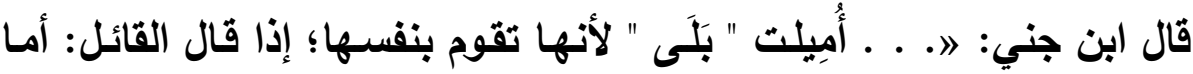
قام زيد؟ قال لـه المجيب: بلى، فلما حسن الوقوف عليها أميلت، أمسارة لمشـابهة

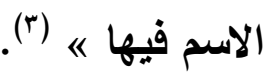
ولم تتأكد إمالتها عند ابن سيدة، لذا جعل ألفها من الواو؛ قال: » لأن الواو

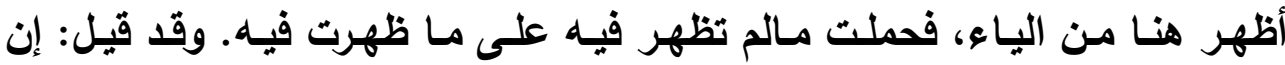

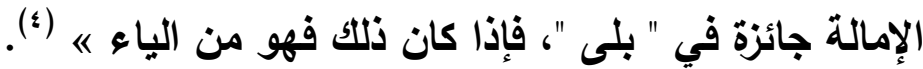

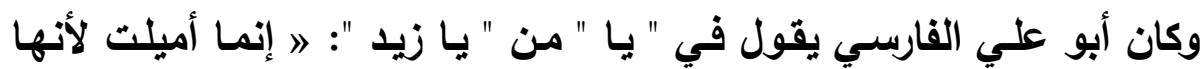

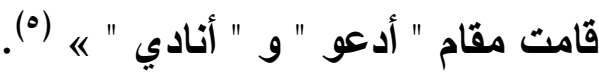

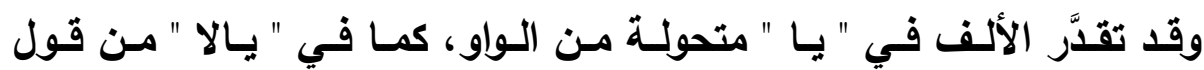

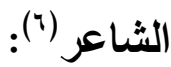

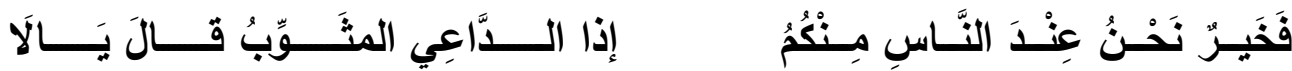
بالوقوف على اللام لتصير الكلمة " يال " مستقلة، ك " باب "، فيحكم للألف

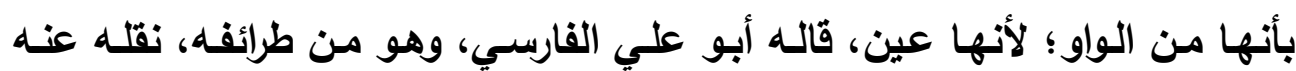

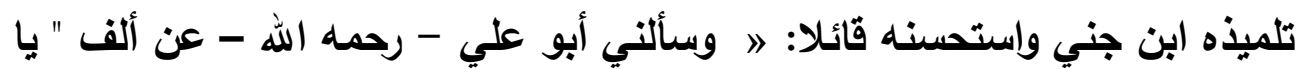

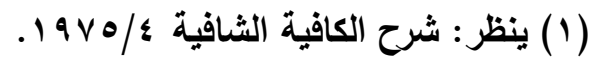

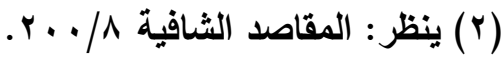

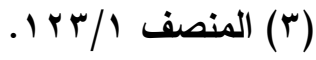

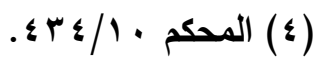

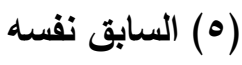

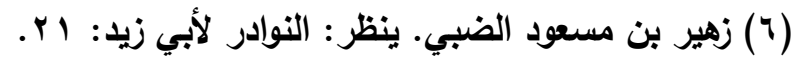


" من قوله: . . . يالا، فقال: أمنقلبةٌ هي؟ قلت: لا؛ لأنها في حرف، أعنس " يـا ".

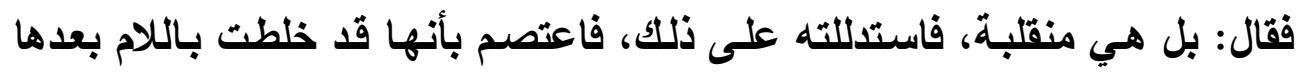

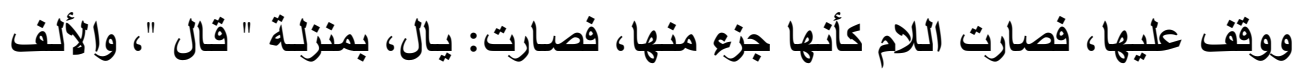

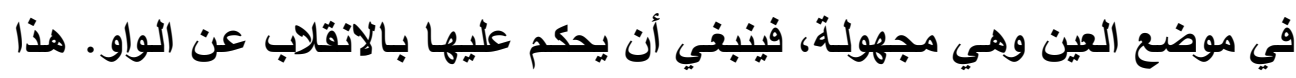

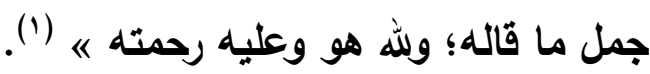

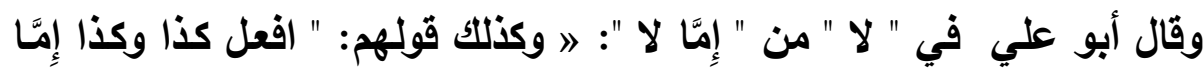

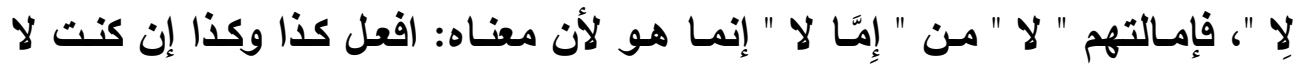

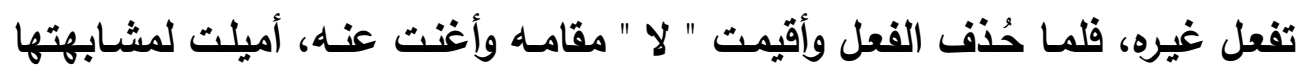
الفعل « (ז). وحكى قطرب عنهم: لِا أفعل كذا، بإمالة " لا "، ووجهه ابن جنـي باستقلالها

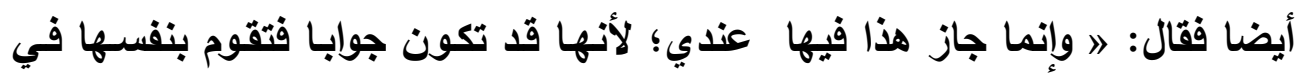

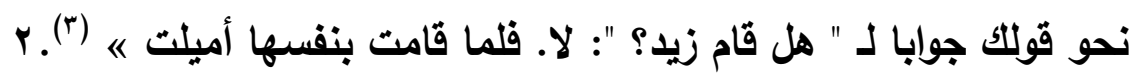

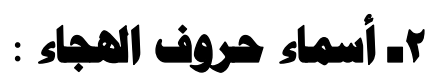

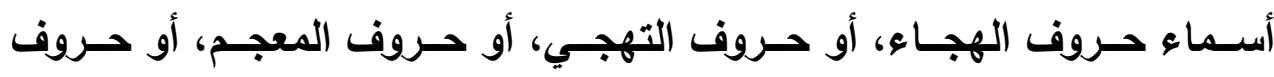

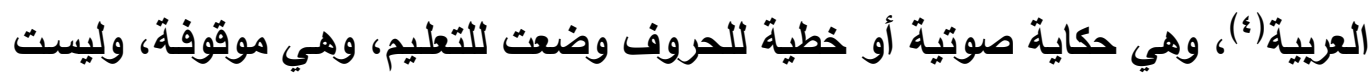

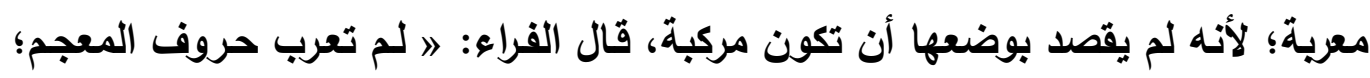

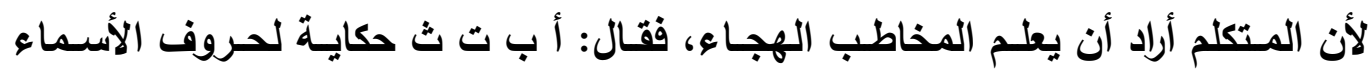

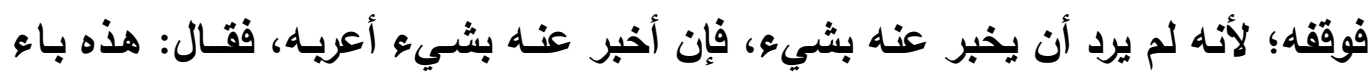

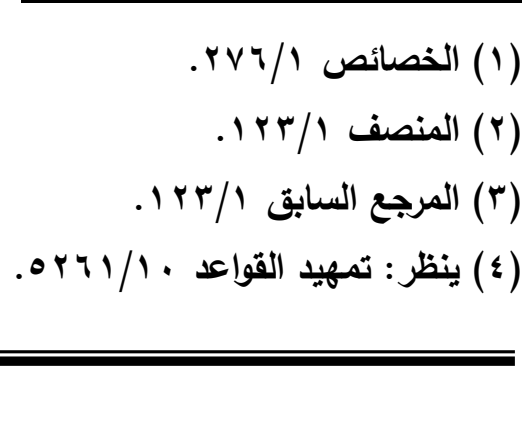


قصيرة، وكذا إن نسق فقال: هذه ألف وياء « (')، لذا جاء بعضها على أقل من ثُلاثة

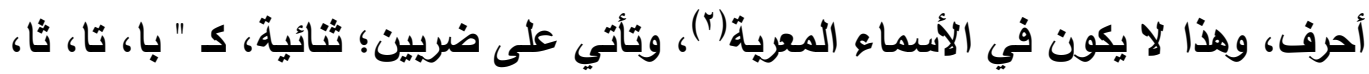

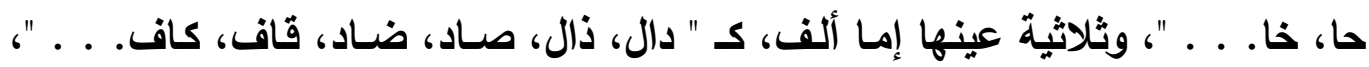

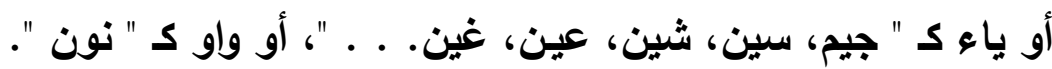

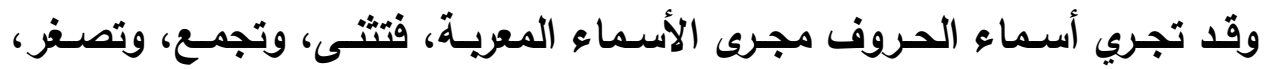

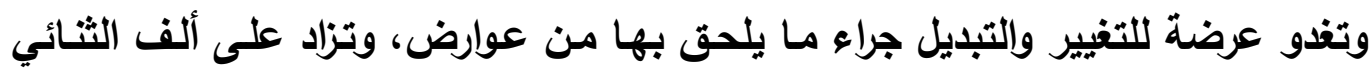

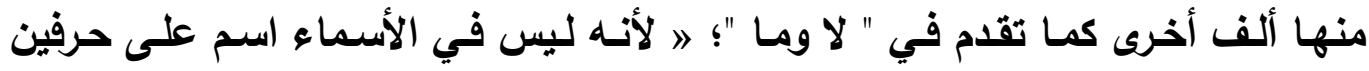

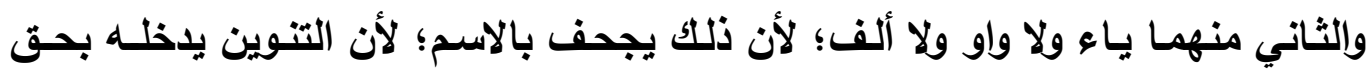

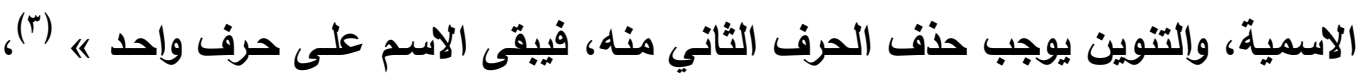

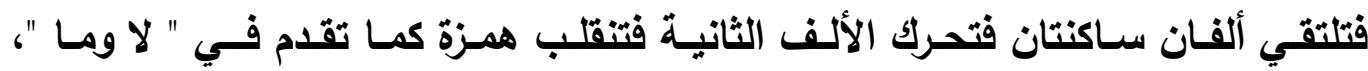

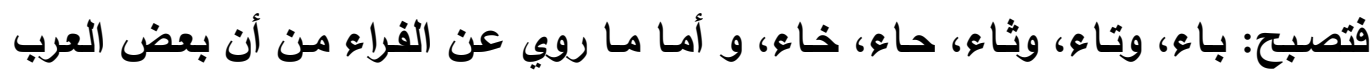

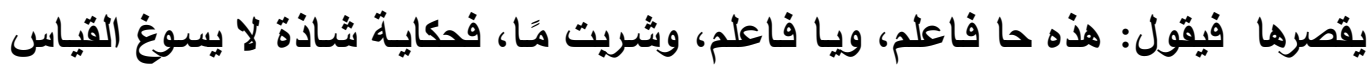

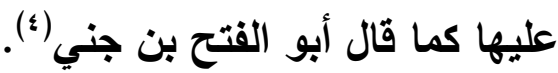
وهاتان الألفان العين واللام في: باء، وتاء، وثاء، وحاء، بعد زيادة عدة اللفظ

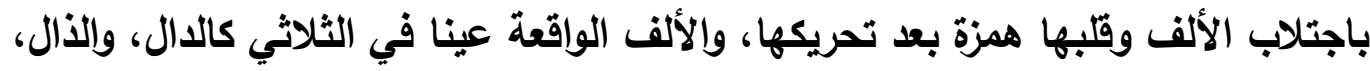

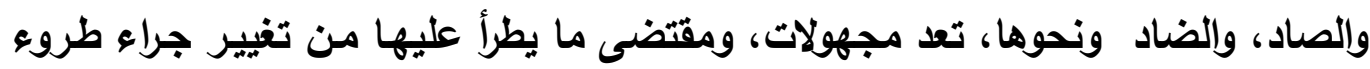

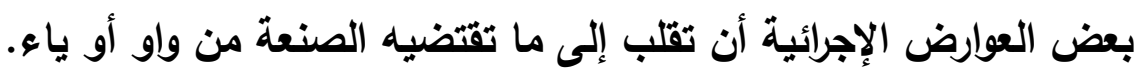

(1) صناعة الكتاب لأبي جعز النحاس: ؟ ؟ V.

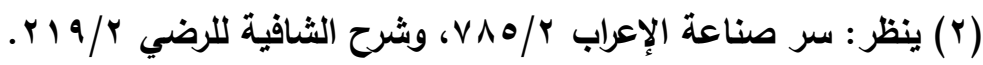

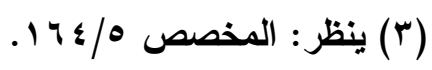

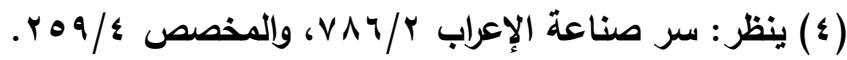




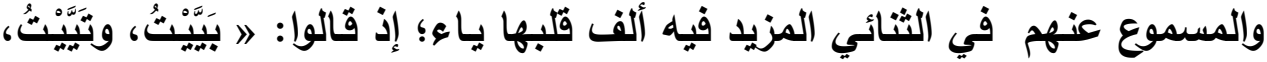

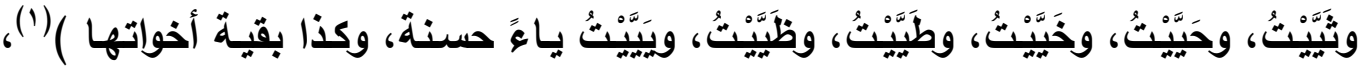

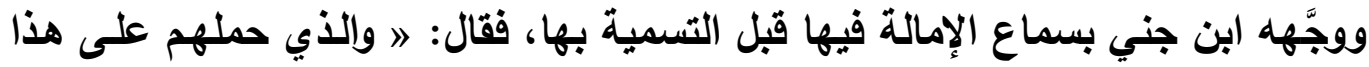

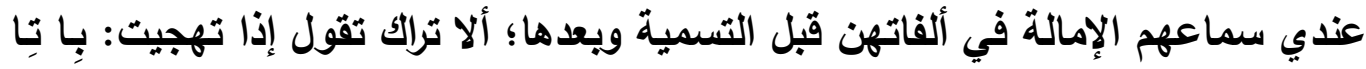

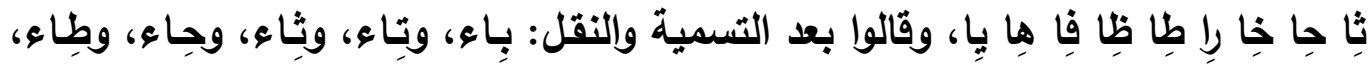

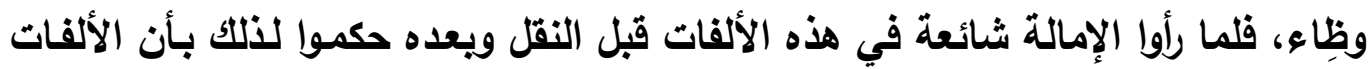

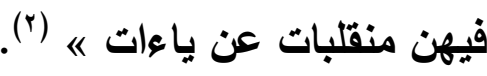

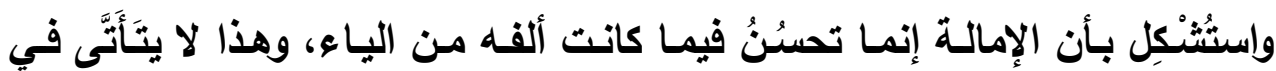

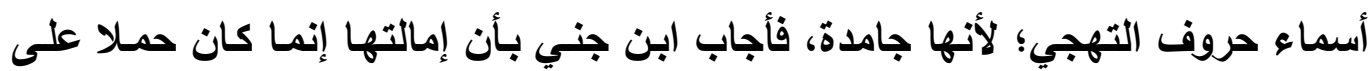

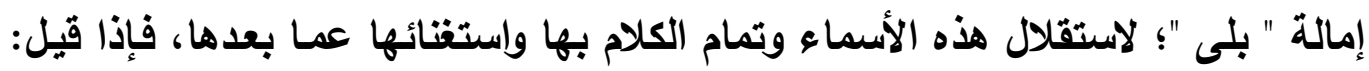

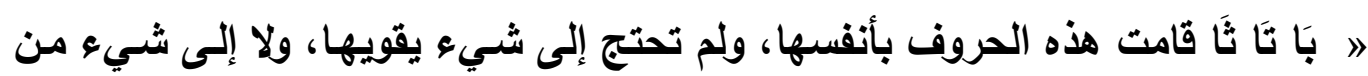

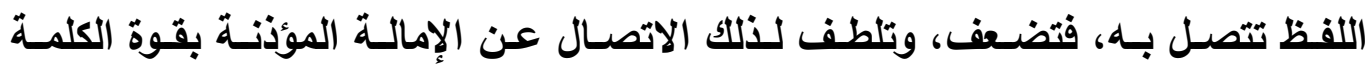

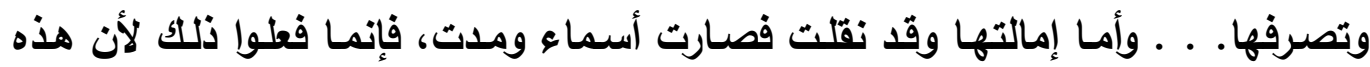

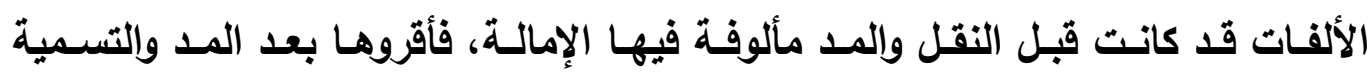
والإعراب بحالها؛ ليعلموا أن هذه الممدودة المعرية هي تلك المقصورة قبل النقل المبنية،

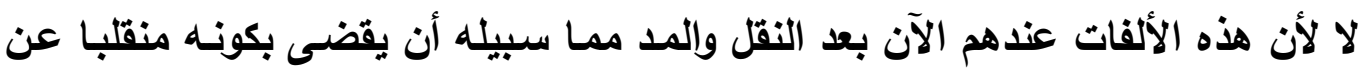

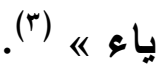

$$
\begin{aligned}
& \text { (1) سر صناعة الإعراب r/r (1) } \\
& \text { V V }
\end{aligned}
$$

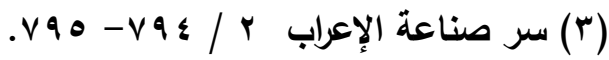


وقال الخليل: 》 الحاء: حرف هجاء مقصور موقوف، فإذا جعلته اسما مددته،

تقول: هذه حاء مكتويـة، ومدتها ياءان، وكل حرف على خلفتها من حروف المعجم

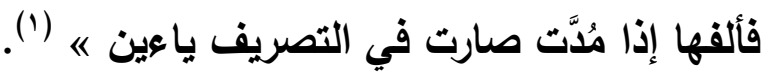

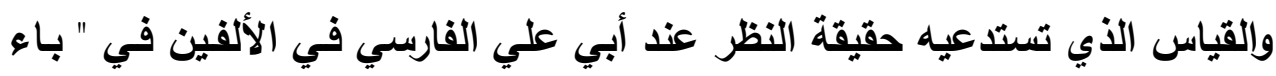

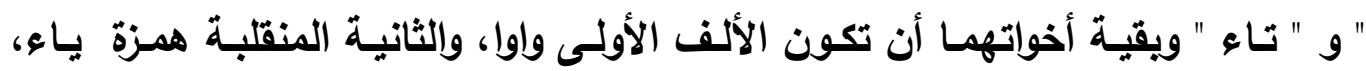

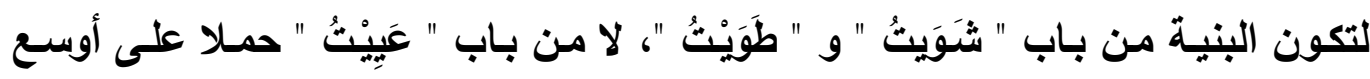

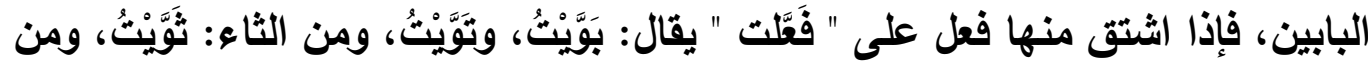

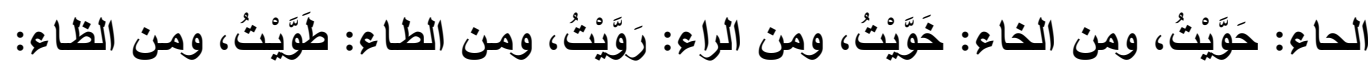

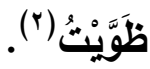

ولم يكترث ابن جني بإمالة هذه الأسماء؛ لأن إمالتها إنما لحق بها شبها بالأسماء

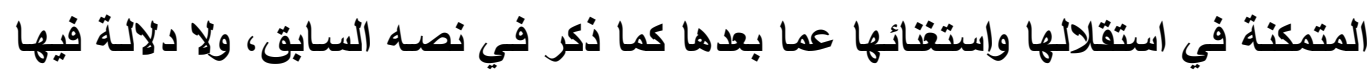

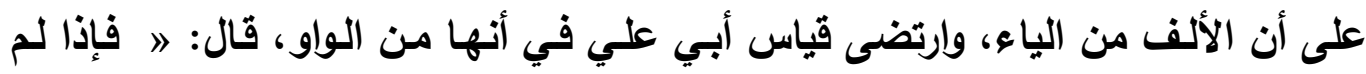

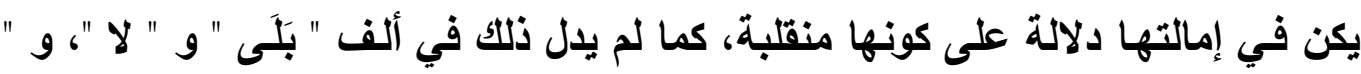

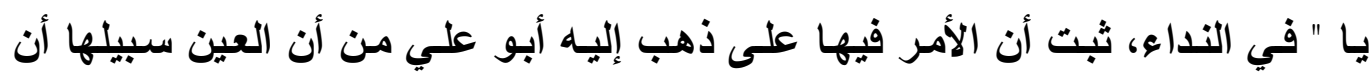

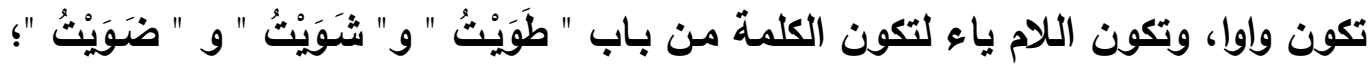

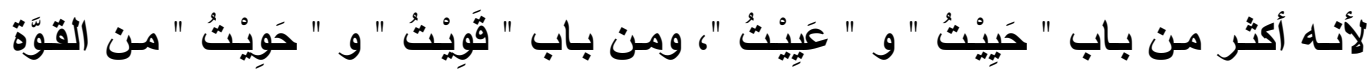
والحوَّة. فلو لم يكن في هذا إلا الجنوح إلى الكثرة والرجوع إليها عن القلّة لكان سبيا

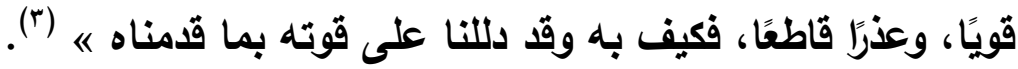


وريما استُعِين بتقدير الألف في الثنائي من الواو في توجيهه قراءة، كما في قراءة

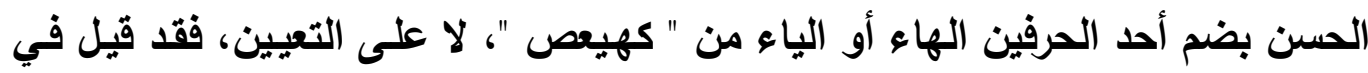

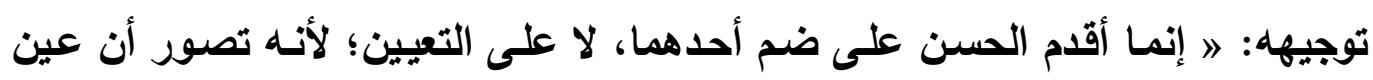

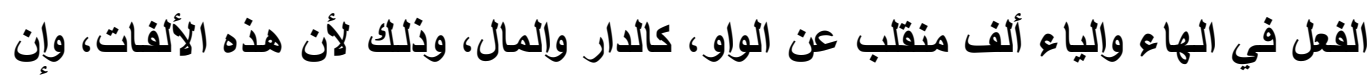

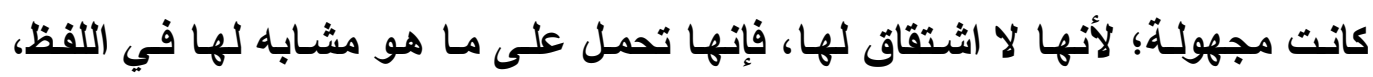

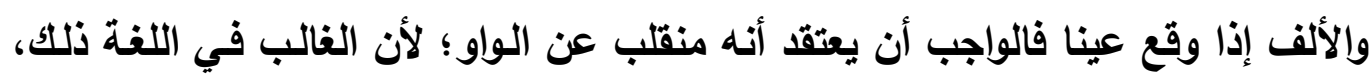

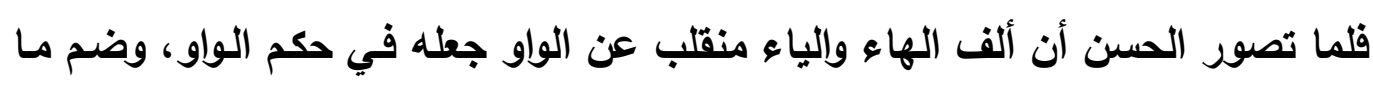

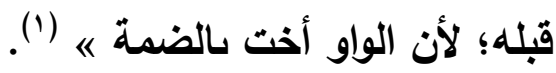

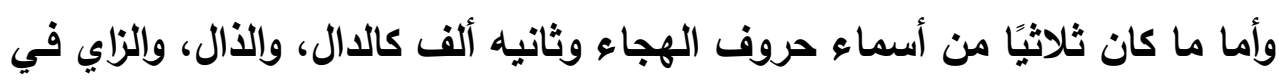

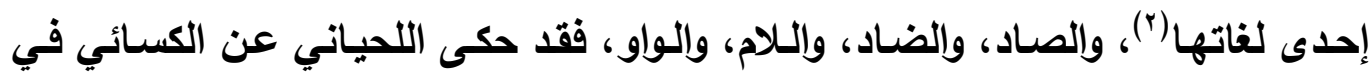

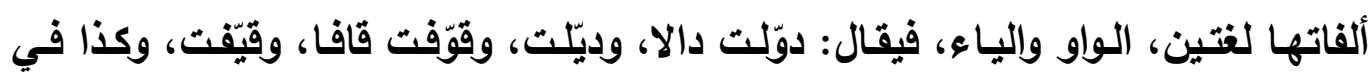

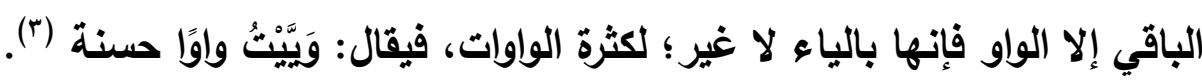

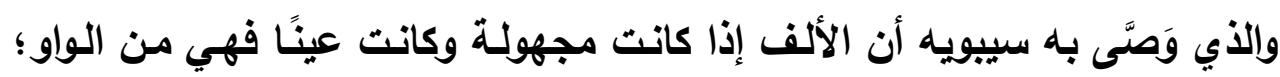

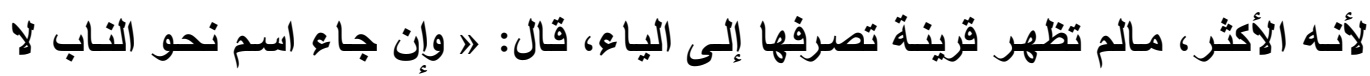

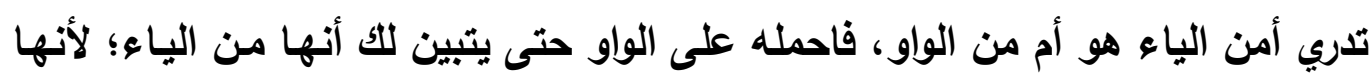

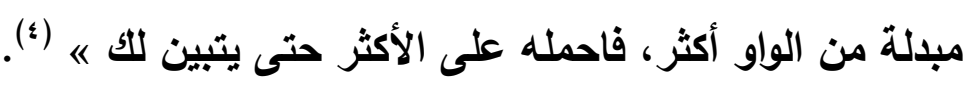

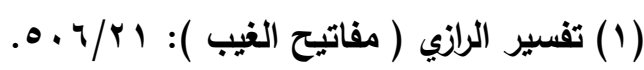

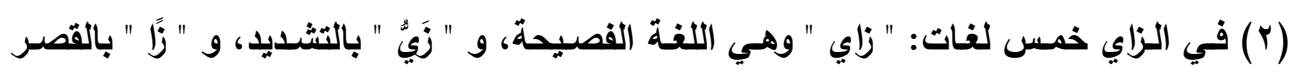

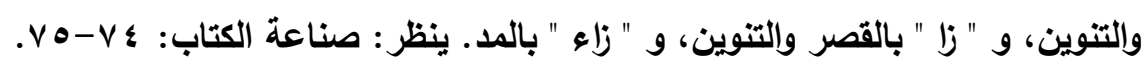

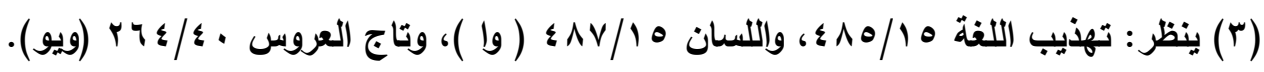

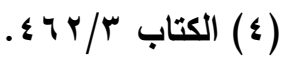


وعلى هذا اتكأ ابن جني في تقديره لما تؤول إليه الألف المجهولة في هذه الأسماء

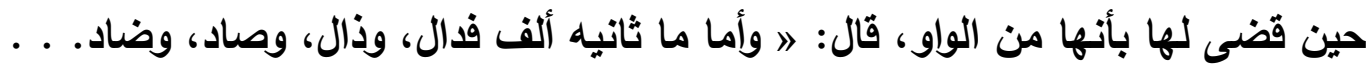

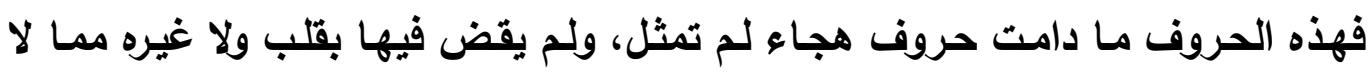

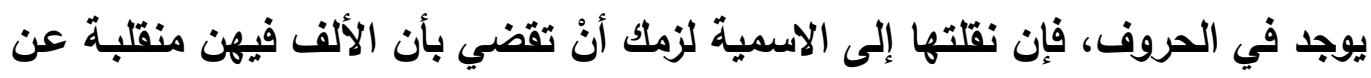

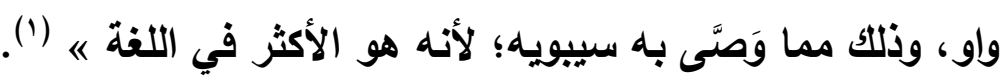
وكذا عند ابن سيده(؟). واختُلفِ في الألف في " واو "، فقي حكاية السيوطي المذكورة قيل أنها من الياء لا

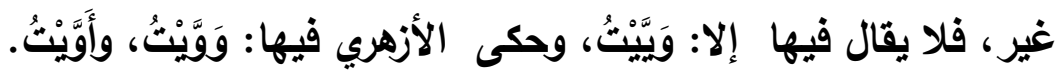

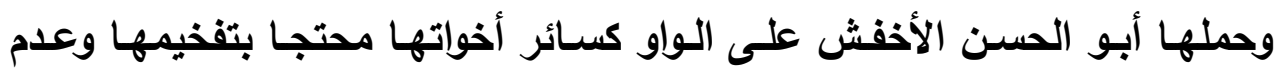

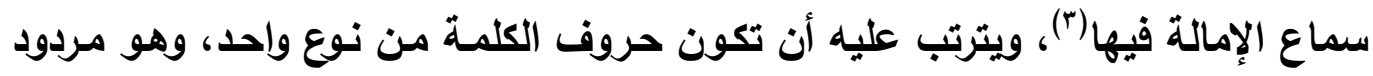

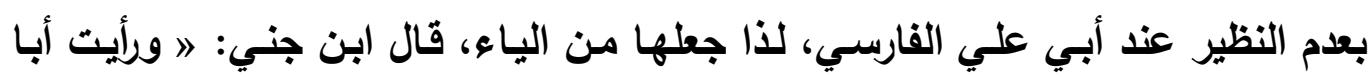

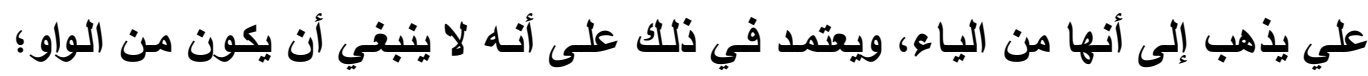

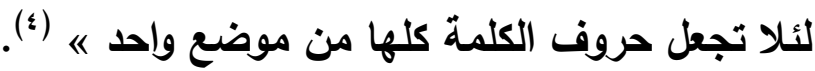

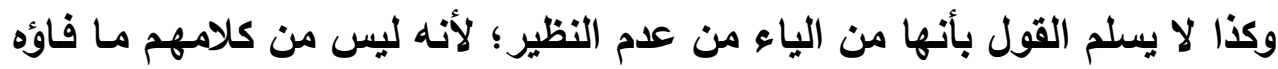

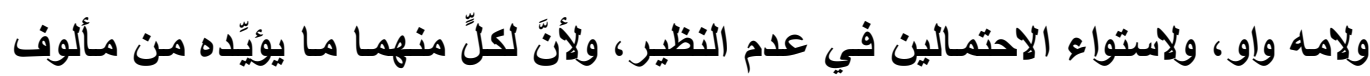

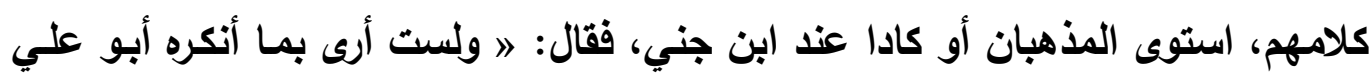

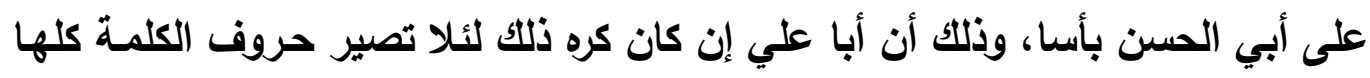

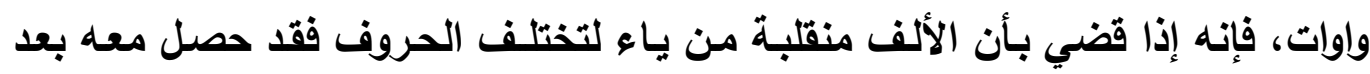

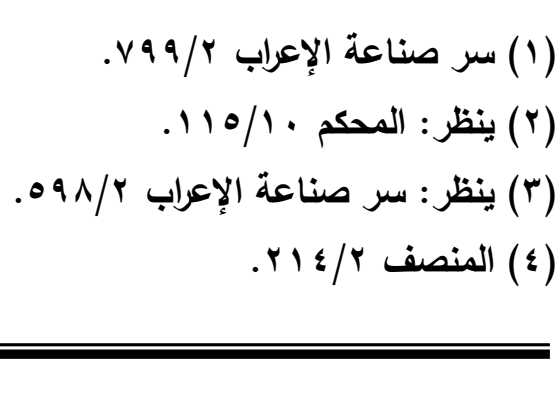


ذلك لفظ لا نظير له؛ ألا ترى أنه ليس في الكلام حرف فاؤه واو ولامه واو إلا قولنا: واو،

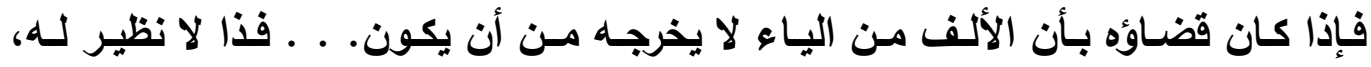
فقضاؤه بأن العين واو أيضا ليس بمنكر، ويعضد ذلك أيضا شيئان:

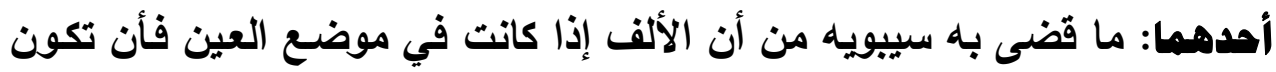

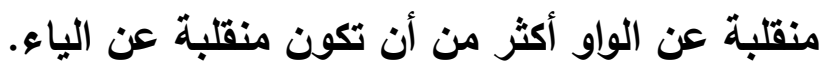
والآخر: ما حكاه أبو الحسن من أنه لم تسمع عنهم فيها الإمالة، وهذا أيضا يؤكد

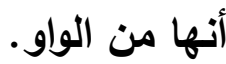
ولأبي علي أن يقول منتصرا لكون الألف منقلبة عن ياء: إن الذي ذهبت أنـا إليه

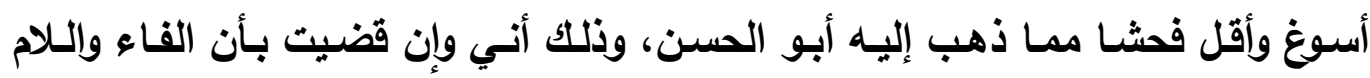
واوان، وكان هذا أيضا لا نظير له، فإني قد أريت العرب جعلت الفاء وإللام من لفظ وإحد

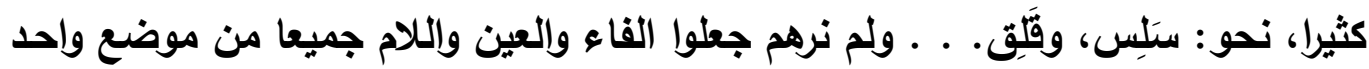

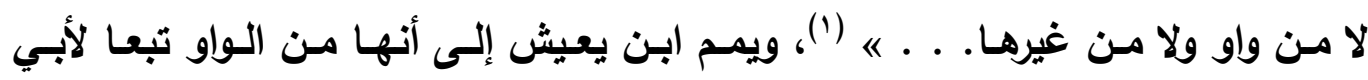

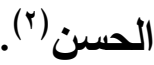

ويتراءى لي أن اختيار الأخفش بجعل الألف من الواو - وإن خالف عاداتهم في

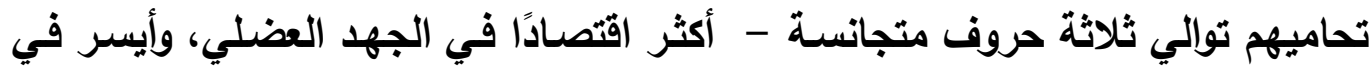

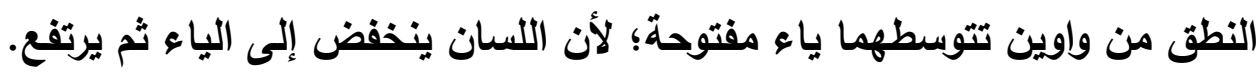

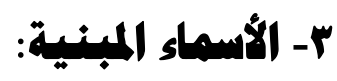

وحالها كما سبق كحال الحروف، وألفاتها أصول غير زوائد ولا منقلبة، إذ لا يعرف لها أصل إلا بالاشتقاق، وهي غير مشتقة ولا متصرفة، ويجري عليها ما يجري

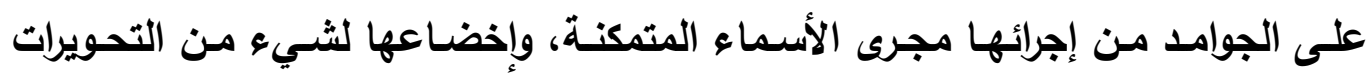

$$
\begin{aligned}
& \text { (1) المنصف / (1) }
\end{aligned}
$$

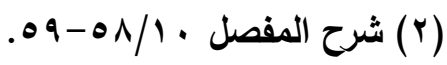


والتبديلات التي تعرض لها، فما كان منها على حرفين أو ثلاثة الثاني منها ألف فالألف

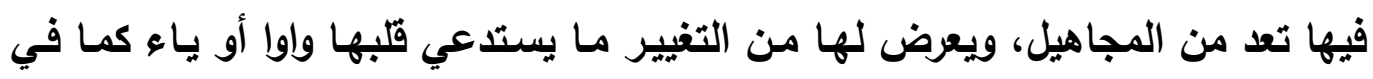

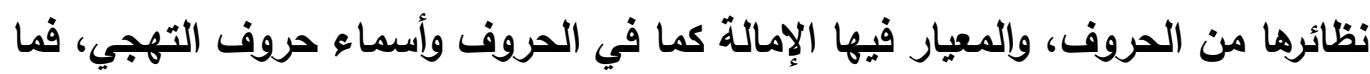

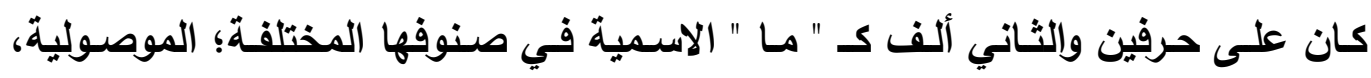
والثرطية، والاستفهامية، وسائر أخواتها، فيجري عليها حين نقلها إلى الأسماء المتمكنة

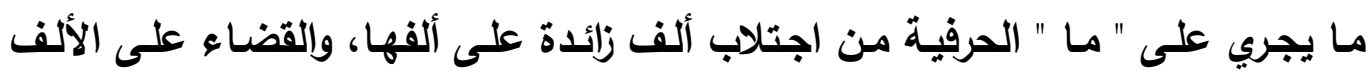

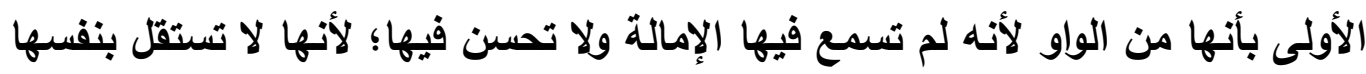

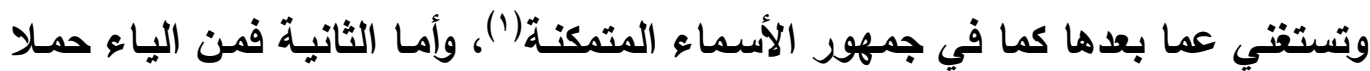

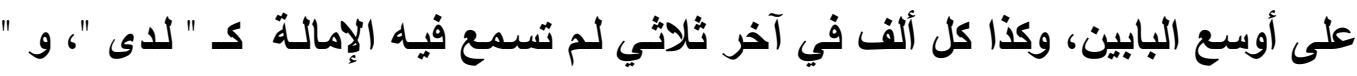

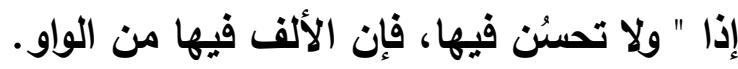

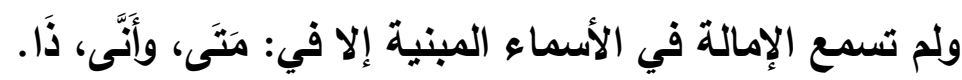

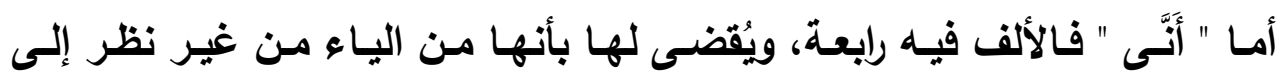
الإمالة. وأمسا " متى " ففي كلتا حالتيها من الاستفهام والثرط غير مضافة؛ لذا أثبهت

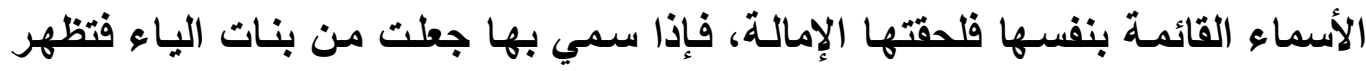

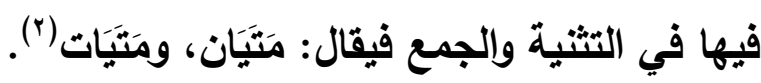

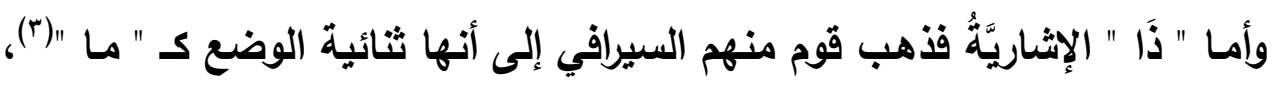

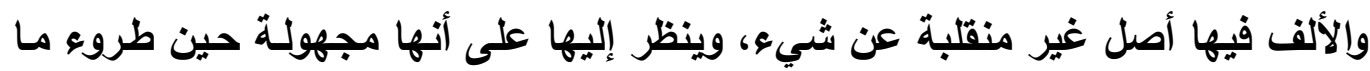

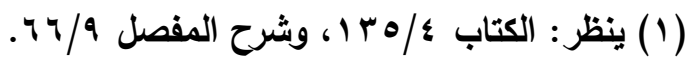

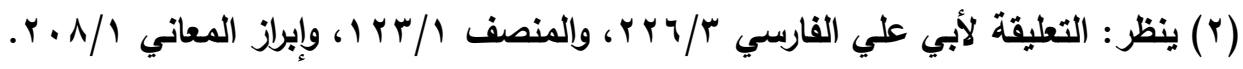

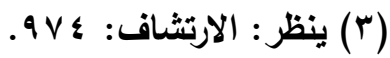


يقتضي قلبها، وجعلت من الياء لثبوت إمالتها عند سيبويه(')، فقيل في تصغيرها: ذَيَّا، وفي تثنيتها: ذَيَّان (r).

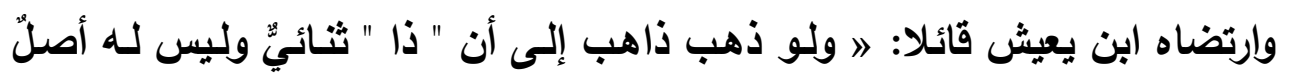

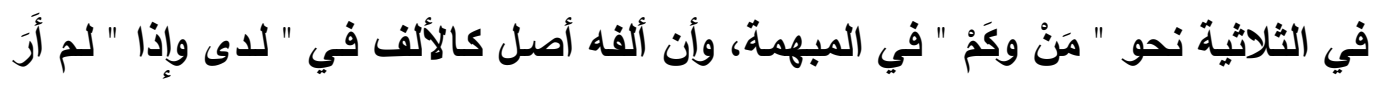

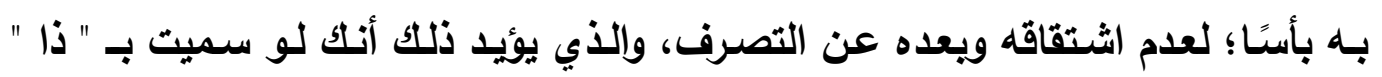

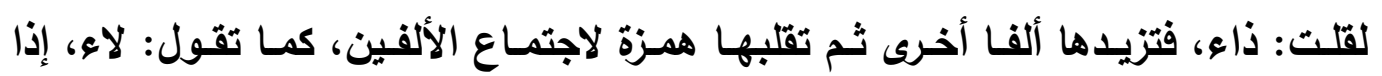

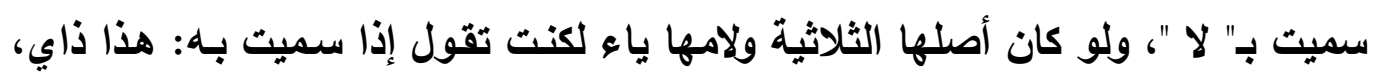

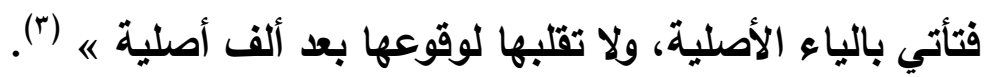

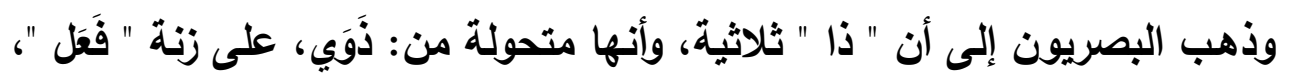

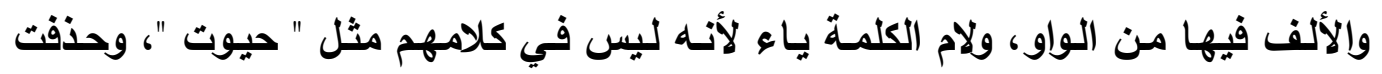
تأكيدا للإبهام (๕) وقيل: أصلها: ذَيٌْ، بتثديد الياء، على زنـة " فَعْل "، فحذفوا الياء الثانيـة تخفيفا

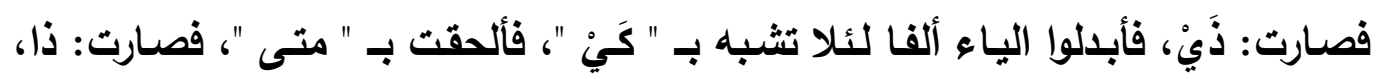

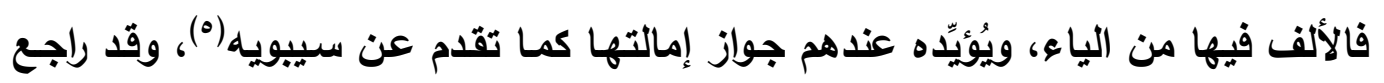
ابن جني أستاذه أبا علي في قرينة كونها من الياء فئاء فئال:

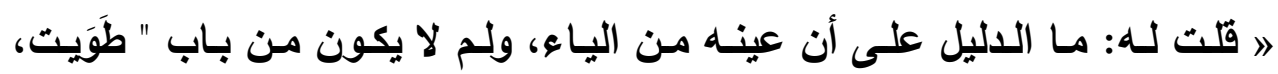

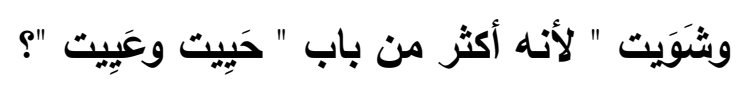

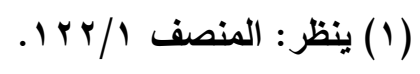

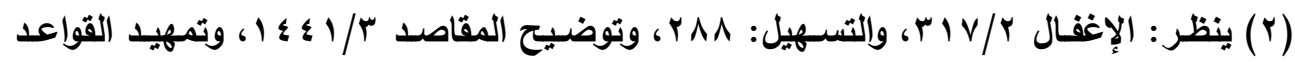

$$
\begin{aligned}
& \text {. ¿Av } 1 / 1 \text {. }
\end{aligned}
$$

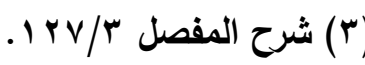

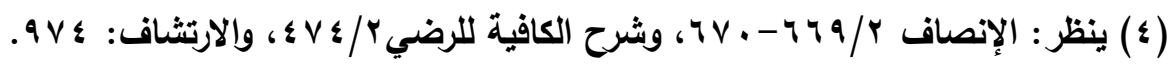

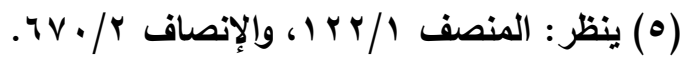


فقال: لأن سيبويه حكى فيه الإمالة، فهذا يـل على أنه من الياء « (1).

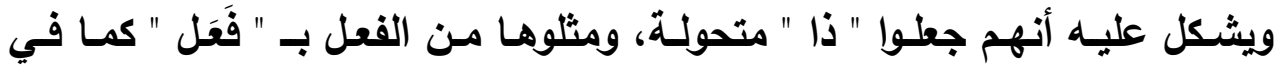
الأسماء المتمكنة، وهي مبنية؛ لذا قَّروا للألف الواو أو الياء لجهل أصلها، فهي إذًا في منزلة بين المنزلتين.

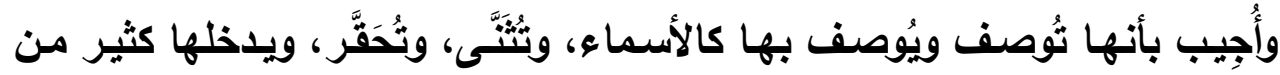

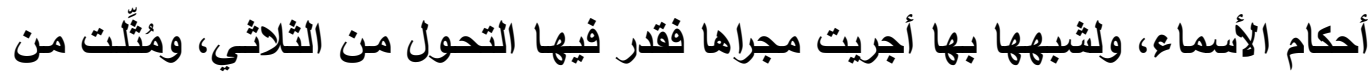

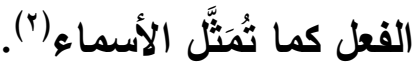
وذهب الكوفيون إلى أن الاسم من " ذا " هو الذال وحدها، والألف زيدت تكثيرًا،

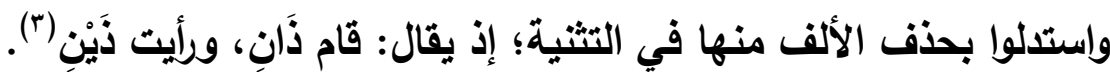
وردَّه أبو علي الفارسي بأنَّ " ذا " اسم مظهر وليس بمضمر بـليل التكنيـة عنهـ بالضمير، فيقال: هذا ضريته، كما يقال: زيل أكرمته، ويوصف كما في: مررت بهذا الرجل العاقل، وتصف به كما في: مررت بزيد هذا، وإذا ثبت أنه مظهر، فالمظهر لا يكون على حرف واحد(؛)، وأن " ذَانِ " و" ذَينِ " صيغتان مرتجلتان للتثنية(ه). ومن الألفات المجهولة في الأسماء المبنية مـا نجده في بعض أسماء الأصوات، S: " غَاق " لصوت الغراب، و " جَاه " لزجر البعير، و " حَاء "، و " عَاء " لزجر الضئين، و " قَاع " لزجر الغنم، و " طَاق " لصوت الضرب، و" خَاز بَازِ " لصوت طيران الذباب، و و

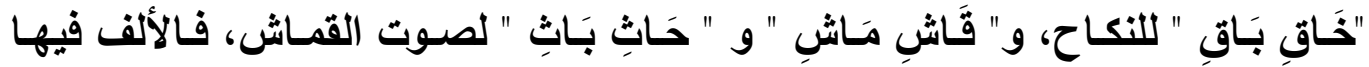


كالألف في " قَاف " و" كاف " و " دال " من أسماء حروف التهجي (1)، يقضى لها بأنها

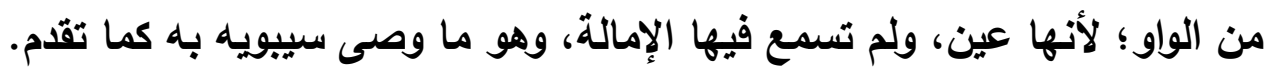

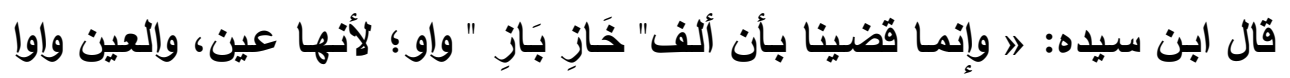

$$
\text { أكثر منها ياء }
$$

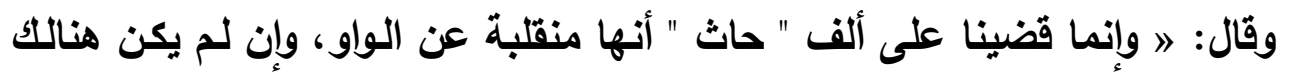

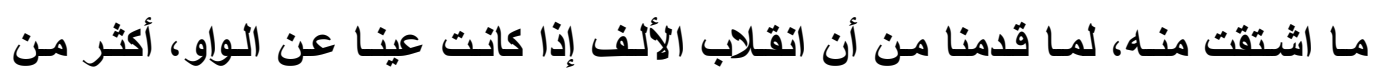

$$
\text { انقلابها عن الياء « ("). }
$$

وقال: 》 وإنما قضينا على ألف " قاق " بأنها واو؛ لأنها عين، وإلعين واوا أكثر

منها ياء « (؛)

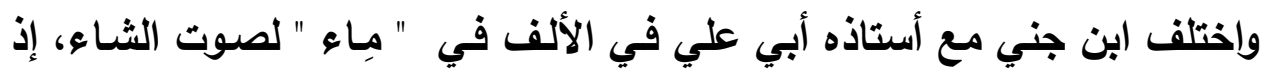

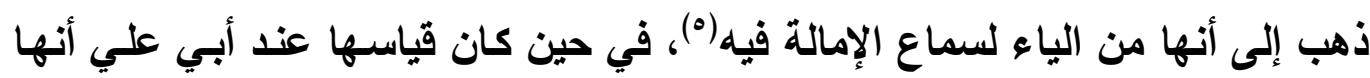

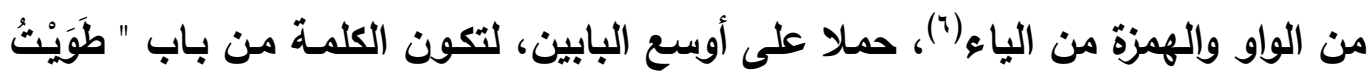

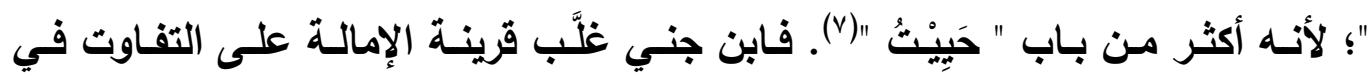
الاستعمال خلافا لشيخه الأي قدم كثرة الاستعمال ولم يكترث بالإمالة.

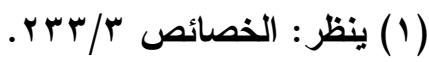

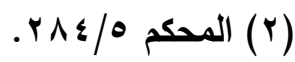

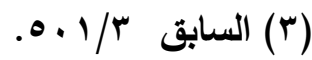

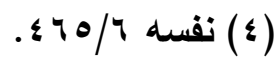

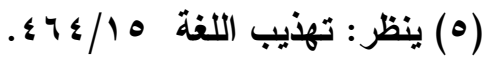

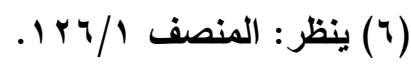

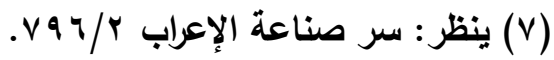


وإن كانت الألف لامًا كما في " هلا "، وهي: كلمة زجر للخيل، فيقضى عليها بأنها

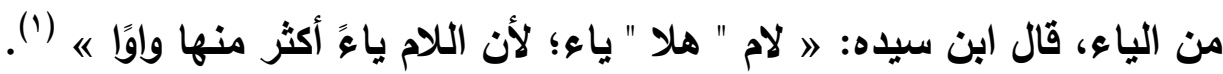

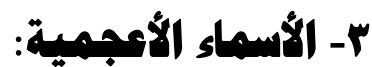

وهي الكلمات الاخيلة أو المعرَّة، وحكمها حكم الحروف في جمودها وإمتاعها

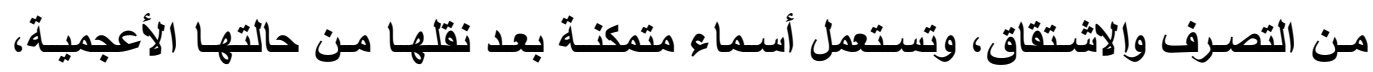

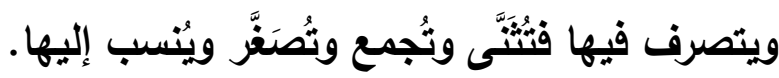
قال أبو الفتح بن جني: » اعلم أن الأسماء الأعجمية النكرات التي دخل علئه عليها

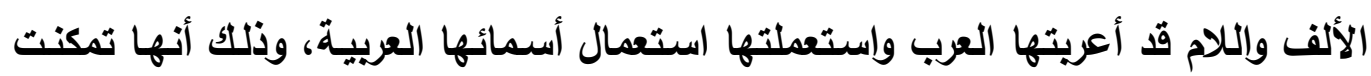

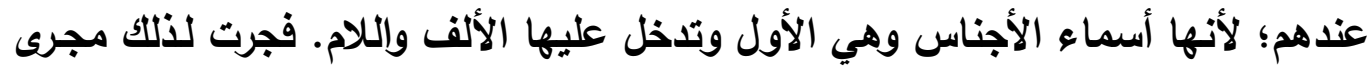

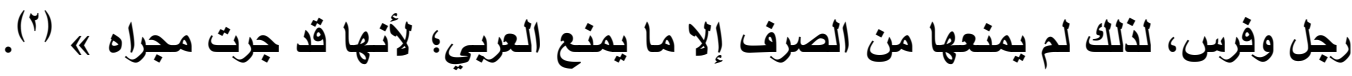

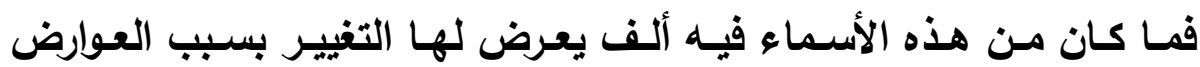

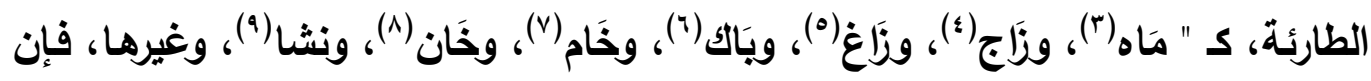

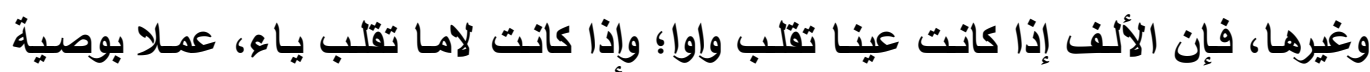

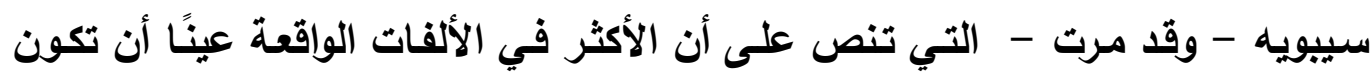

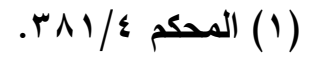

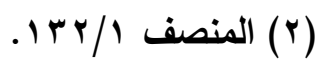

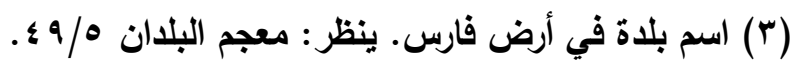

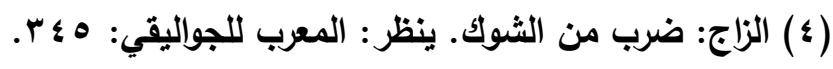

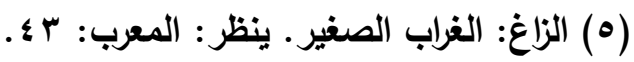

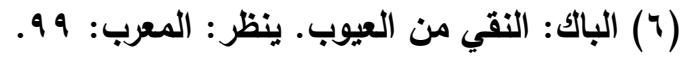

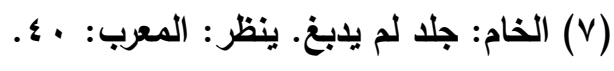

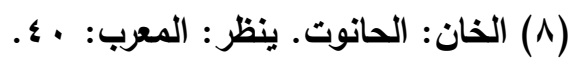

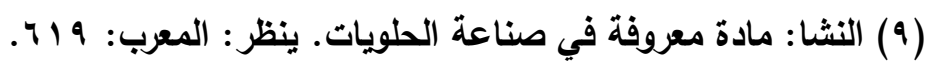


من الواو، والألفات الواقعة لامًا تكون من الياء، إذا لم تكن هناك قرينة تعين على تعيين

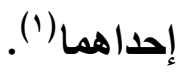




\section{ثانياً: الألف المبدلة}

أو المنقلبة، وتكون - كما سبق - في الأسماء المتمكنة والأفعال؛ لأنها تستجيب للتحوير والتبديل، فيعرض للألف فيها التحريك جراء طروء عوارض مختلفة على البنية، وإذا حركت روجع فيها الأصل الأقرب.

وقد يتوارى أصل الألف في اسم متمكن أو فعل لسبب مـا، فتغدو مجهولة، ويحتم ما يعرض لها من تحريك أن يقدر لها أصل من الواو أو الياء كما في الحروف والأسماء المبنية وغيرها، التي كانت فيها الألف أصلا غير مبدلة، وقد مر أن سيبويه يحتكم في تقدير أصل الألف في ذلك ونحوه إلى معياري الإمالة، وكثرة انقلاب الألف من الواو إذا كانت عينا، وكثرة انقلابها من الياء إذا كانت لاما. فأما الإمالة فأمارة على أن الألف من الياء إن لم تكن هناك قرينـة أوكد على أنها من الواو؛ وإن لم تثبت الإمالة فينظر إلى مقيساس الكثرة في انقلاب الألف في العين والنلام، وقد نص عليه سيبويه في الأسماء حين قال: " وإن جاء اسم نحو الناب لا تدري أمن الياء هو أم من الواو، فاحمله على الواو حتى يتبين لك أنها من الياء؛ لأنها مبدلة

من الواو أكثر، فاحمله على الأكثر حتى يتبين للك ه (1).

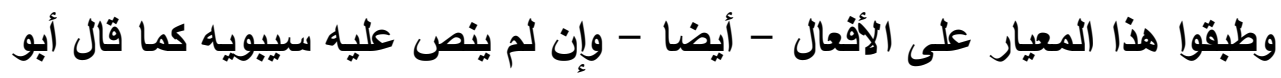
علي الفارسي( (†)، واستأنسوا بقرائن وأدلة أخرى كالحمل على نظير، وكثرة دوران المـادة، والالتقاء مع مادة مماثلة بثيء من المعنى، وفساد الصيغة، ونحوها. وخالف الأخفش سييويه فحمل ما كانت الألف فيه عينًا على الياء لخفتها، فقال

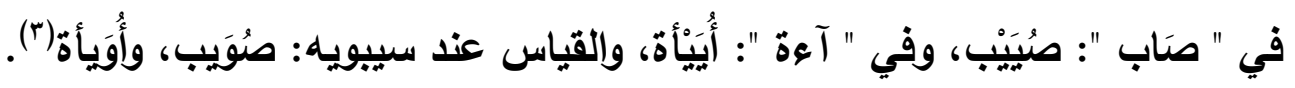


وقد رصدت شيئًا من الأبنيـة التي تأولوا فيها أصل ألفاتها وفقًا لتلك المقاييس

فوجدت منها المقضي له بالواو، ومنها ما قضي له بالياء، ومنها ما اختُّف فيه.

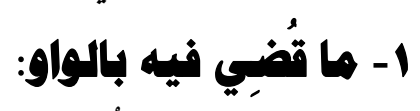

ممـا قُضِي لـه بـالواو من الألفـات المجهولـة بالأسـماء والأفعال قد يكون في

\section{موضع العين، أو في موضع اللام: \\ أ - ها كانت الألف فيه عيناً:}

حقُّ الألف ما دامت عينًا أن تكون من الواو؛ لأنه الأكثر -كما سبق - ما مالمان دام لم تسمع فيها الإمالة، ولم تكن هناك قرينة تصرفها إلى الياء، وقد تمسَّك بهذا ابن جني وجعل قياستًا واحتفى بـه في تحقيق مرجـع الألف الواقعة عينـا فيمـا استوقفه من

الألفات المجهولة، ومن هنا قضى على ألف ( لَيَة )

و( ثََيَةة ) وهي الحجارة، و(طَايَةة) وهو سقف البيت، بأنها منقلبة عن واو (1).

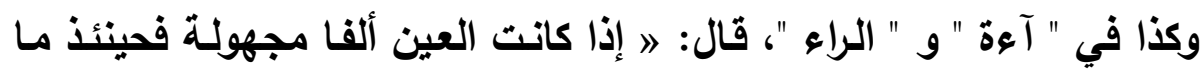

تحتاج إلى تعديل الأمر فتحمل على الأكثر، فلذلك قال في ألف " آعة " إنها بدل من واو،

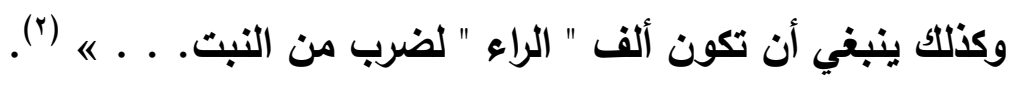

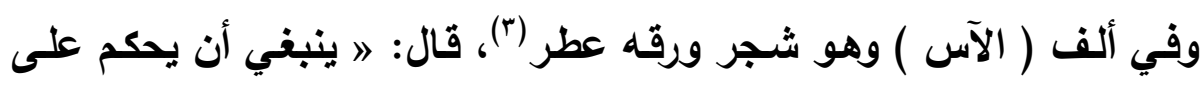

ألفه بأنها من واو حملا على الأكثر عند عدم الاليل « (؛).

وقد يحتال للفظة من حيث الاشتقاق فيدرجها في مادة تلتقي مـع مادتها

لمقارية في المعنى مع الاستدلال بكونها عينا، كما في:

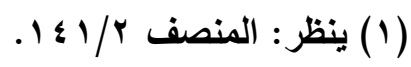

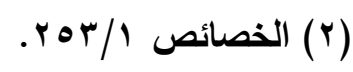

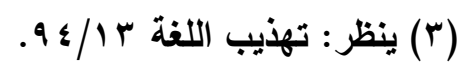

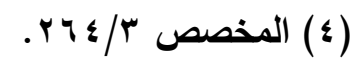




$$
\text { الصنَّبُ: وهو ضرب من الشجر المر. }
$$

قال: 》 عين الصاب واو قياسا واشتقاقا، أما القياس فلأنها عين، والأكثر أن تكون واوا. وأما الاثتقاق؛ فلأن الصاب شجر إذا أصاب العين حلبها، وهو - أيضا - شجر إذا شق سال منه الماء، وكلاهما في معنى " صـاب يصوب " إذا انحدر

(')

وألفيت ابن سيده أكثر من يعول على هذا المقياس في تفريقه بين الواوي واليائي

في " المحكم "، ومما قضى فيه بذلك من الأسماء: الحَاذ: وهو نبت، وقيل: نوع من الشجر العظام (r).

قال: 》 وإنما قضينا على أن ألف الحاذ واو؛ لما قدمنا من أن العين واوًا أكثر منها ياءًا « (r)

واللَّاجَة: وهي الحاجة، وقيل: الداجة أخف من الحاجة.

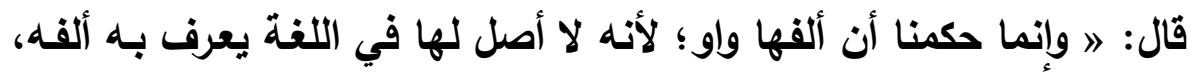

فحمله على الواو أولى؛ لأن ذلك أكثر على ما وصَّانا به سيبويه « (؛).

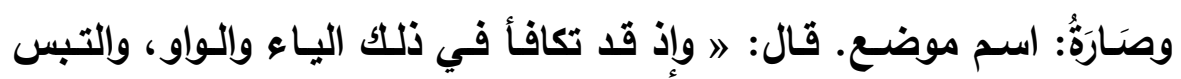

الاشتقاقان، فحمله على الواو أولى « (•).

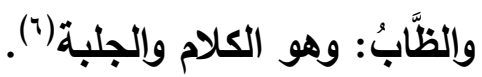

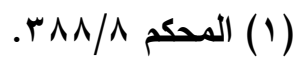

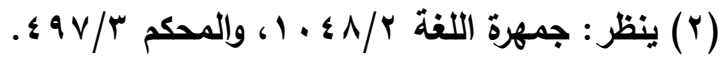

$$
\begin{aligned}
& \text {. }
\end{aligned}
$$

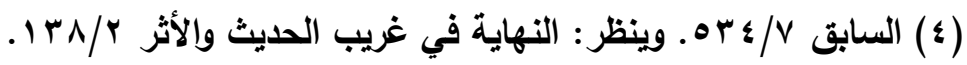

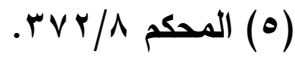

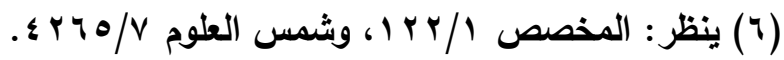


قال: 》 وإنما حملنـاه على الواو؛ لأنـا لانعرف لـه مـادة، فإذا لـم توجد لـه

مادة، وكان انقلاب الألف عن الواو عينا أكثر، كان حمله على الواو أولى « (').

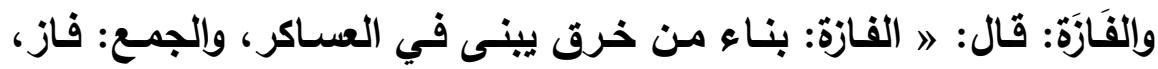

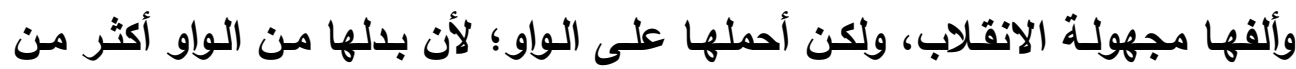
الياء، ولذلك إذا حقر سيبويـه شيئا من هذا النحو أو كسره حمله على الواو أخذا

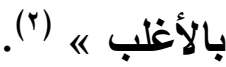

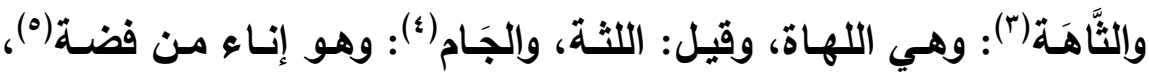

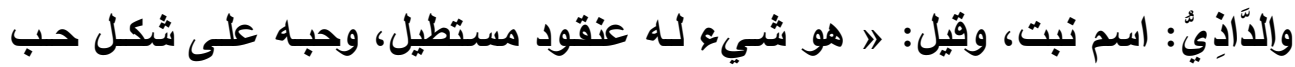
الشعير، يوضع منه مقدار رطل في الفرق، فتعبق رائحته ويجود إسكاره، قال:

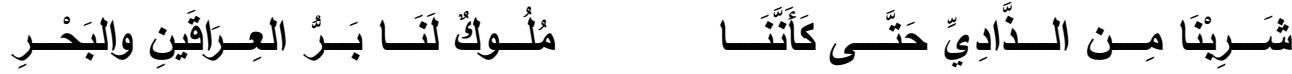
جاء على لفظ النسب وليس بنسب « (") وراذان (v): " راذان الأسفل وراذان

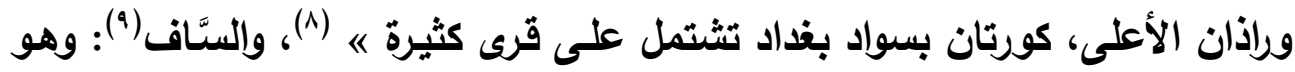
وهو كل عرق من الحائط واللبن (·)، والستَّام: وهو جبل لهذيل (')، والعـاج: وهو

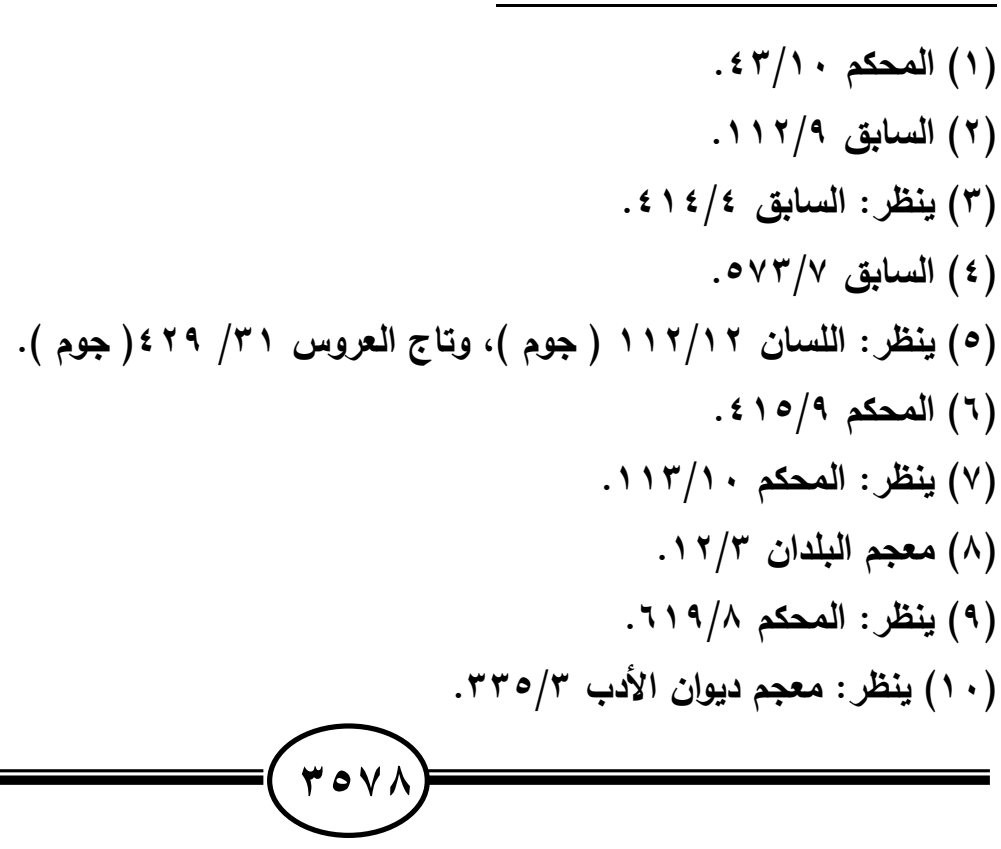


أنياب الفيل(†)، " وفي الحديث: أنه قال لثويـان: " اثتتر لفاطمة سـوارا من عاج "

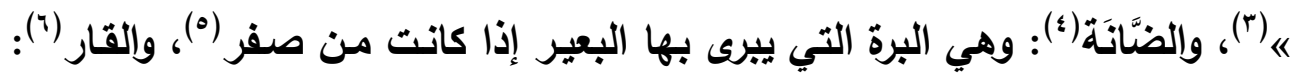

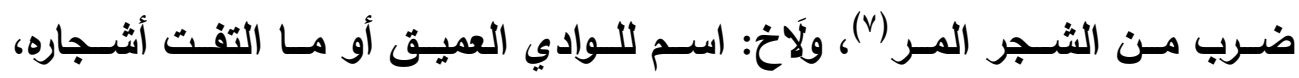

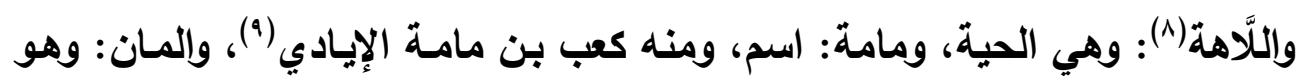

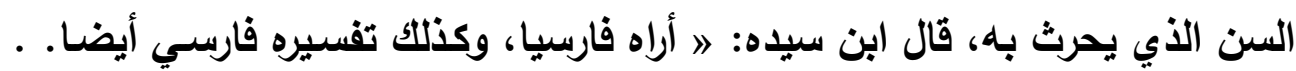

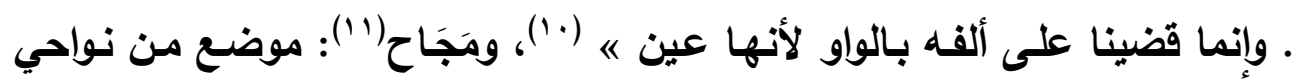

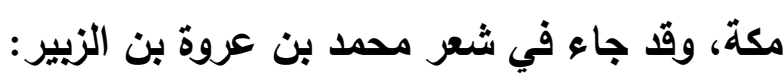

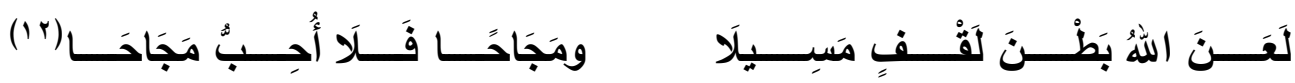
ومن الأنفعال: خَاشَ: أي: حشا، يقولون: خاش الثيء، أي: حثاه في الوعاء.

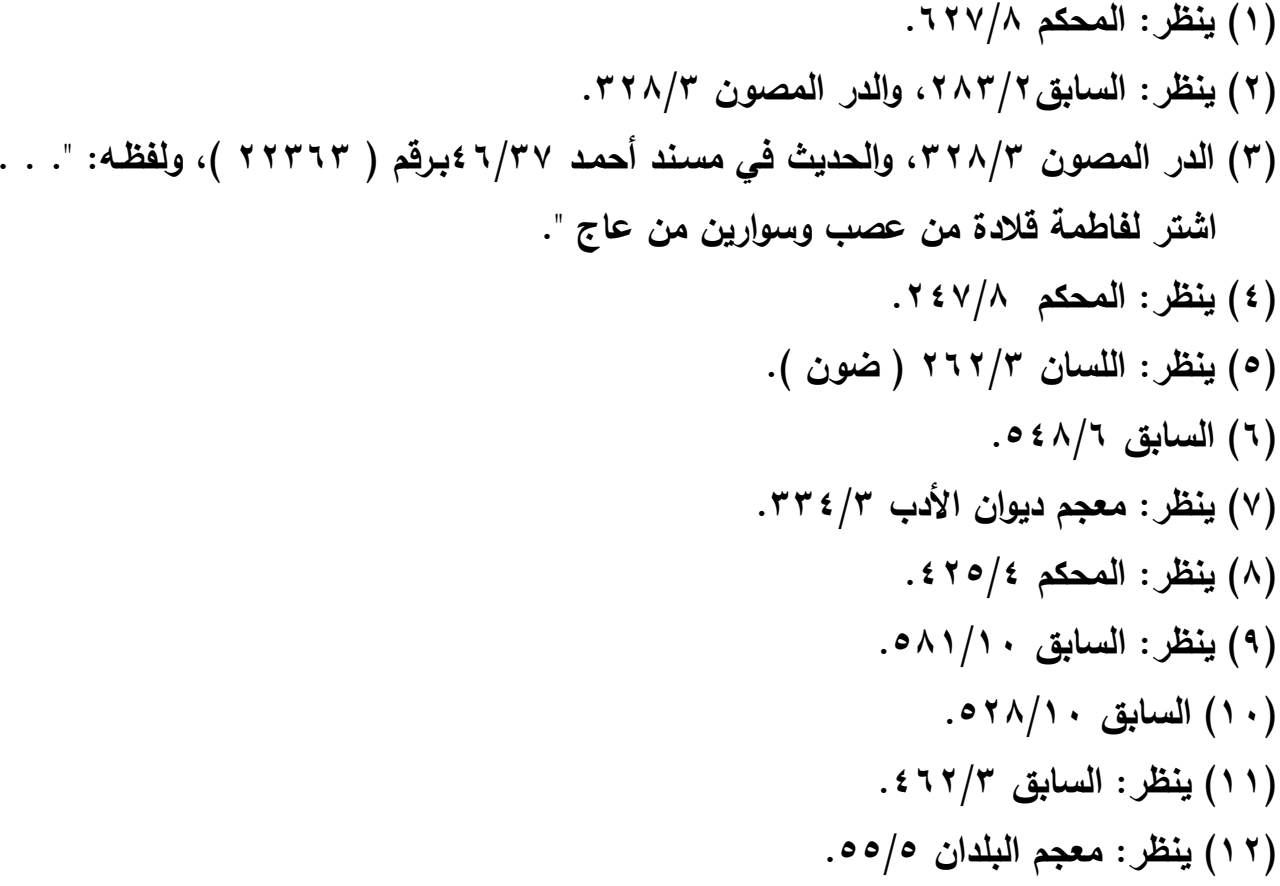


قال ابن سيده: » قال أبو الحسن: وإنما خصصت بـه الواو دون الياء؛

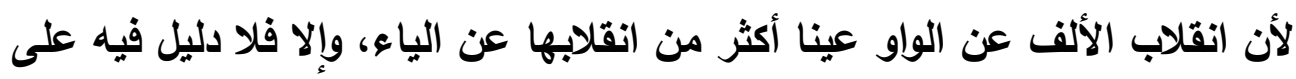

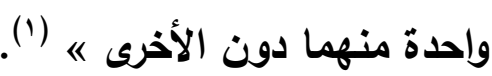
وعَاقَ: » تقول: ما عاقت المرأة عند زوجها ولا لاقتت: أي مـا حظيت عنده .$\left.^{(}\right)$ وينحاش: يقال: ما ينحاش منه، أي: ينفر منه، ومـا ينحاش لثـء؛ أي:

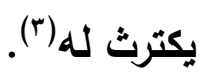
وقد يُحتكم إلى حضـور المـادة في الاستعمال اللغوي، فيُقضسي للألـف المجهولة الواقعة عينا بأنها واو لأنها في استعمالهم لتلك المـادة لم ترد إلا بها،

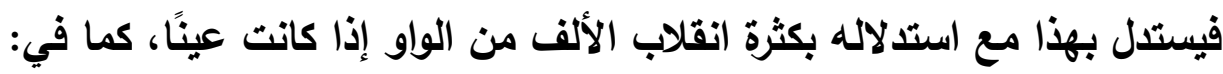

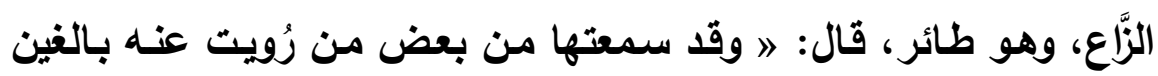

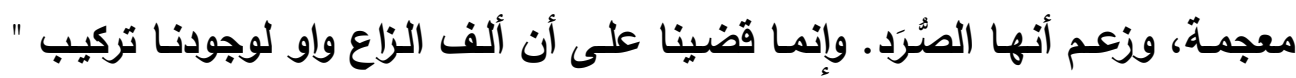

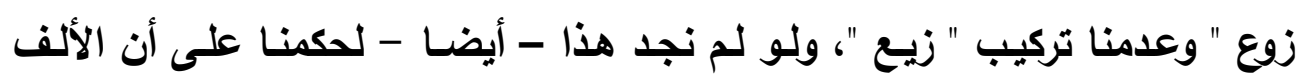

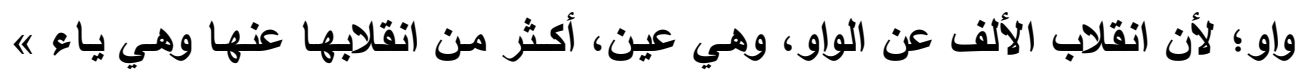

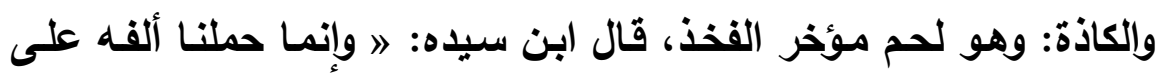

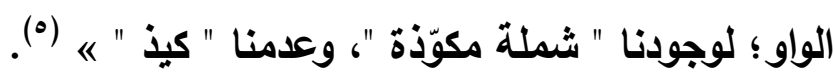

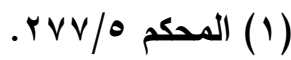

$$
\begin{aligned}
& \text { (r) السابق /rV. }
\end{aligned}
$$

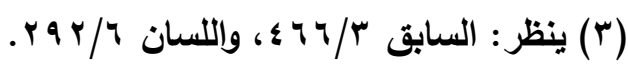

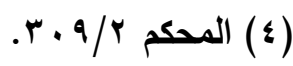

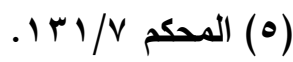


أو تكون المادة مستعملة بالواو والياء ولكنها بالواو أكثر، فيقضى للألف

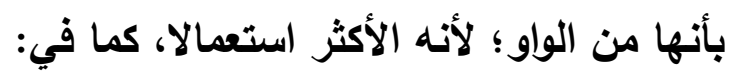

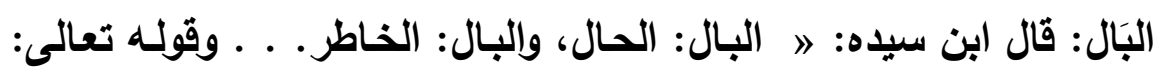

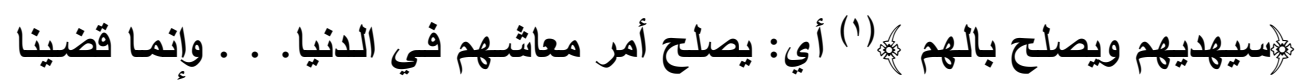

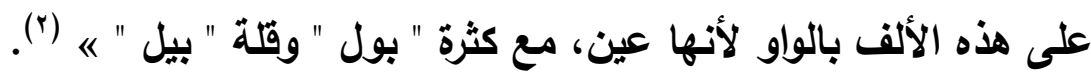

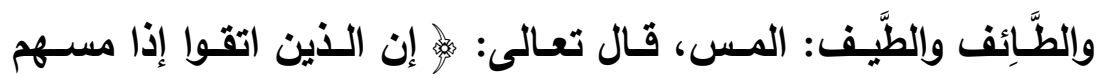

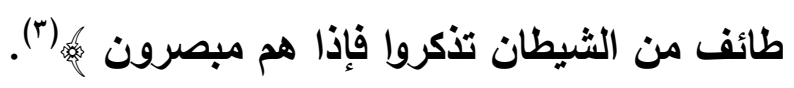

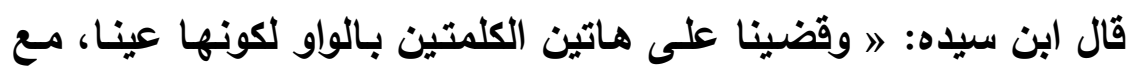

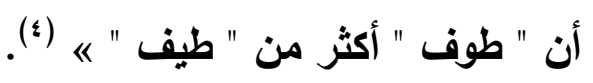

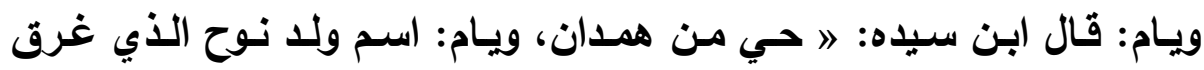

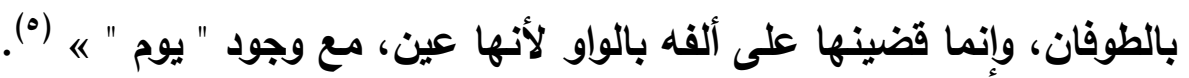

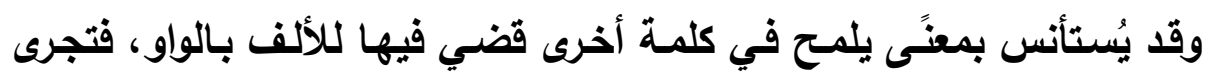

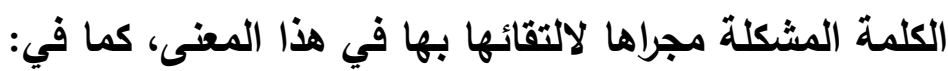

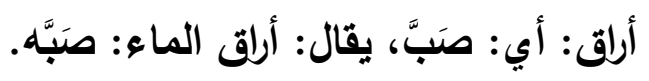

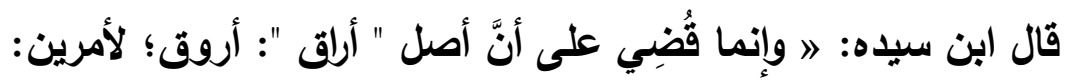

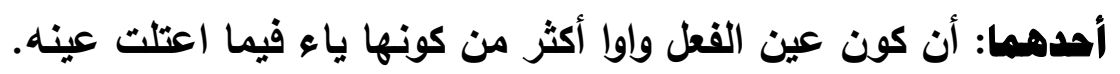

$$
\begin{aligned}
& \text { (1) محمد: 0. }
\end{aligned}
$$

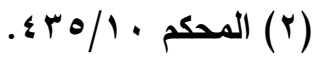

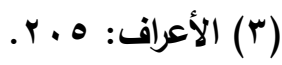

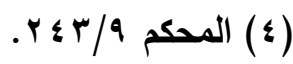

$$
\begin{aligned}
& \text { (0) السابق • 1 / • . هـ. }
\end{aligned}
$$


والآخر: أن الماء إذا هريق ظهر جوهره وصفا، فرلق رائيه يروقه. فهذا يقوي

كون العين منه واوا ه (')

وتارة: يقولون: فعله تارة بعد تارة، أي: مرة بعد مرة. وفي قول الثاعر:

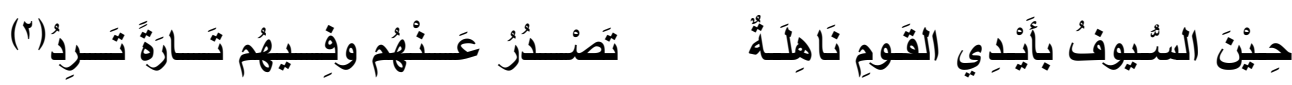

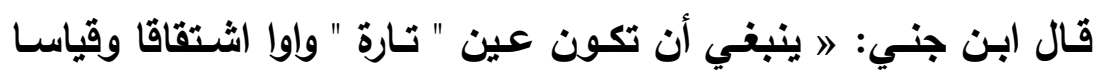

جميعا، أما الاشتقاق فلأنه من معنى " التّوز"، والتّور: الرسول. قال الثاعر:

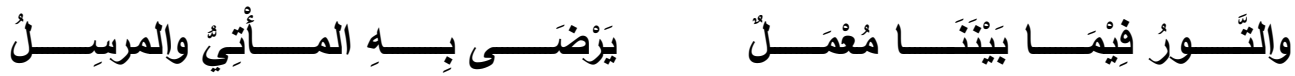

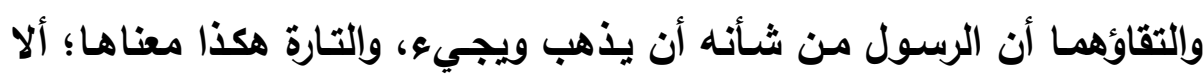

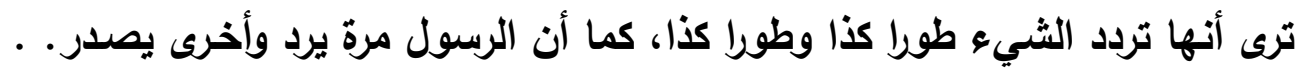

وقد لا يكون المعنى الرابط بين الكلمتين ظاهرا، فيبالغ في تصوره وتوظيفه،

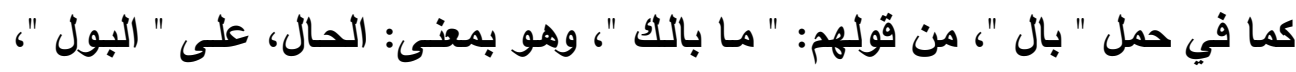

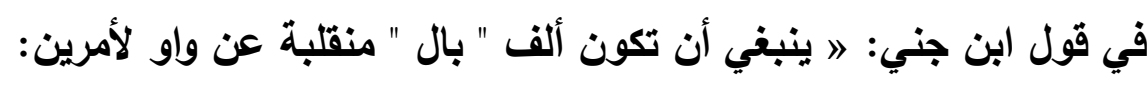

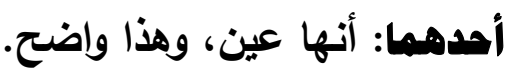

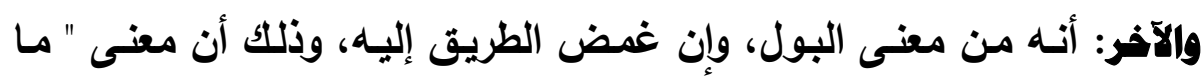

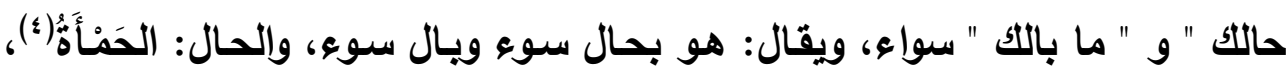

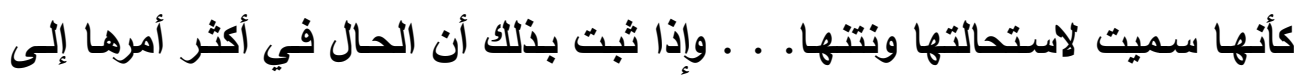

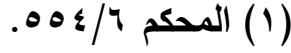

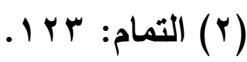

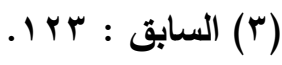

(؛) الحمأة: الطين الأسود. ينظر : التلخيص في معرفة أسماء الأشياء: Y^V. 
التغير المقترن بالفساد، وكان البال بمعنى الحال، لم يمتنع - ايضا - أن يكون من

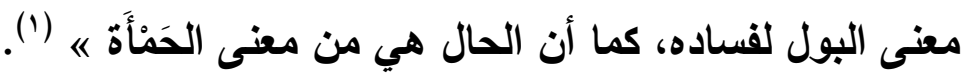
ب - ما كانت الألف فيه لاهما:

وأما ما كان من الألفات في موضع التلام فسيأتي أنها تحمل على

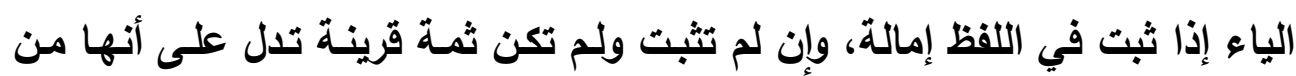
الواو فتحمل على الياء؛ لأنه الأكثر في كلامهم. وأراهم يتحرون حمل الألف الواقعة لامـا على العين العين إن لـم تكن ثمـة إمالـة

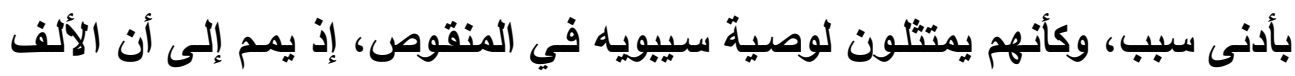

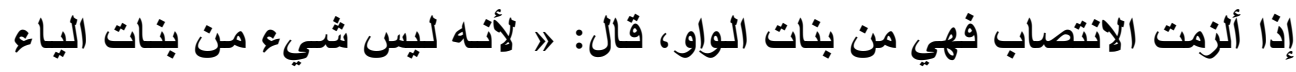

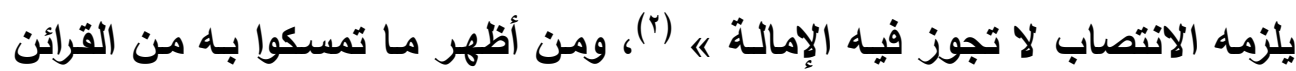

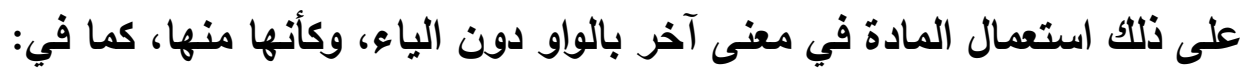

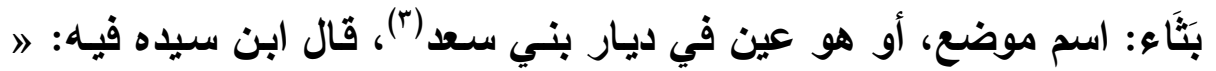

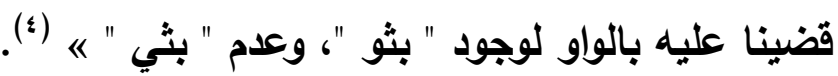

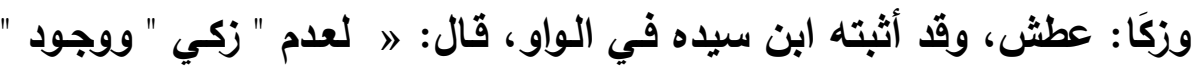
زكو "، قاله ثطب وأنثد:

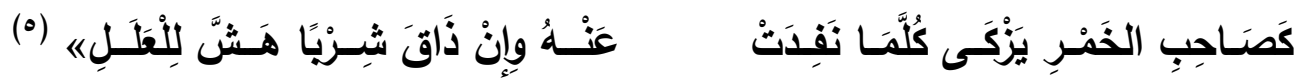


والثثَبَا: وهو واد من أودية المدينة، قضي على ألفه بأنها من الواو لوجود "

$$
\text { شبو " وانتفاء " شبي "(1). }
$$

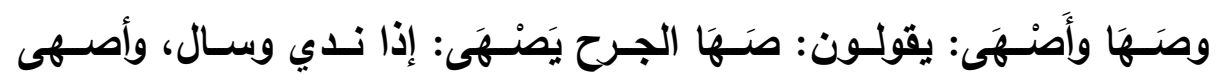

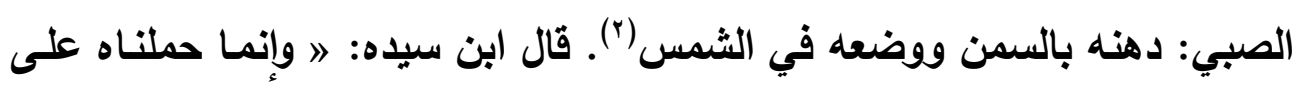

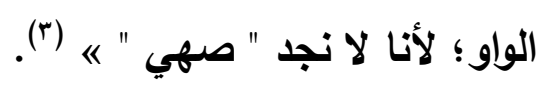

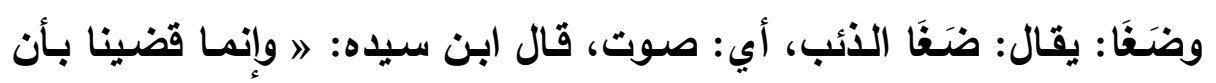

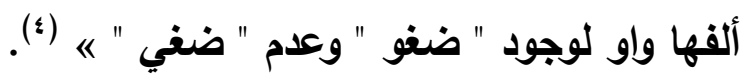

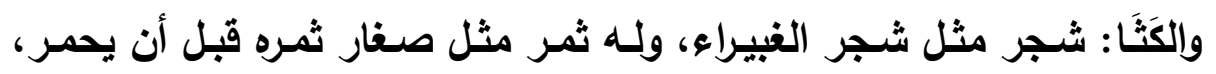

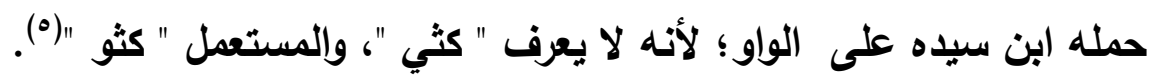

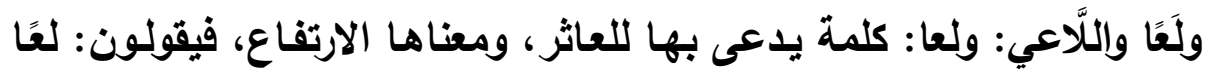

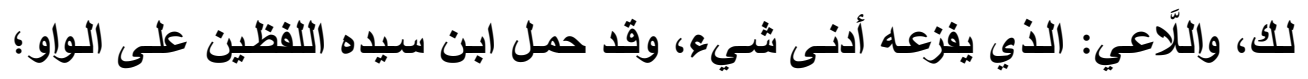

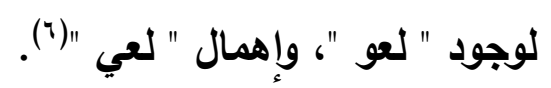

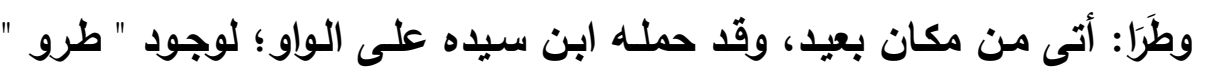

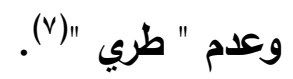
أو يكون استعمال الكلمة بالواو أثهر منها بالياء، فتحمل الألف على أوسع فيع

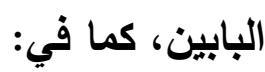

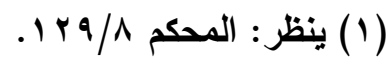

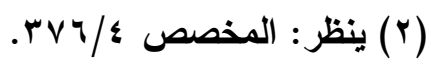

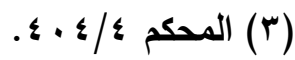

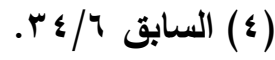

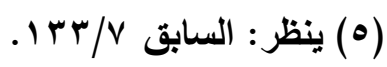

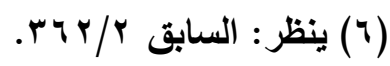

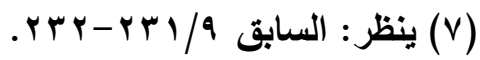


بدا: وهي قريـة بوادي عذرة قرب الثـام (1)، واسم لما يخرج من دبر الرجل،

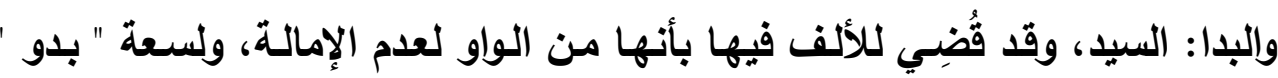

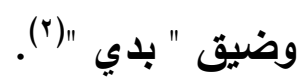

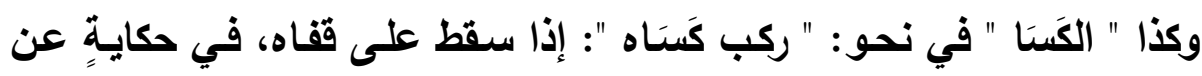

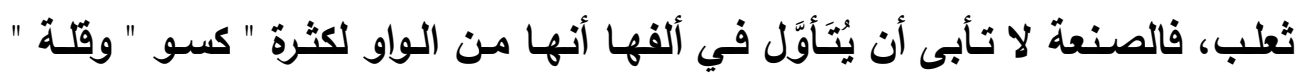

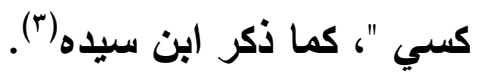

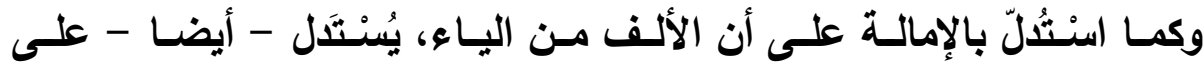

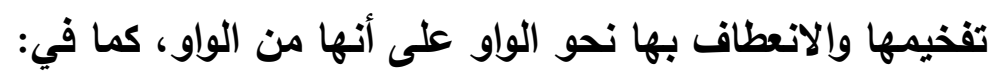

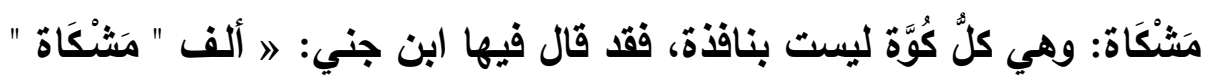

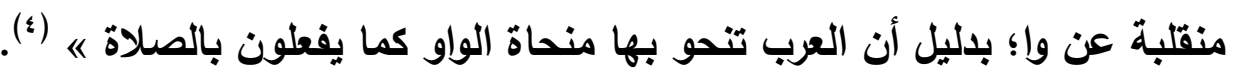

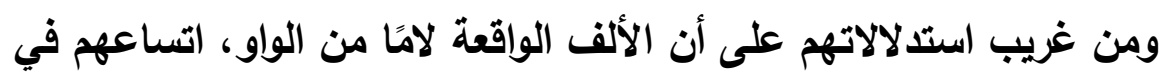

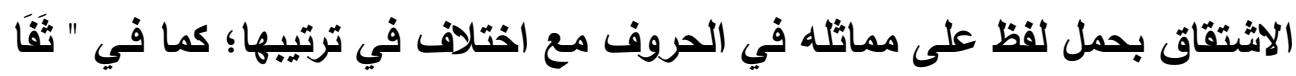

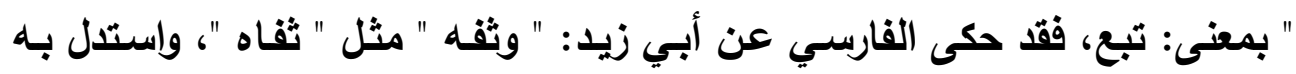

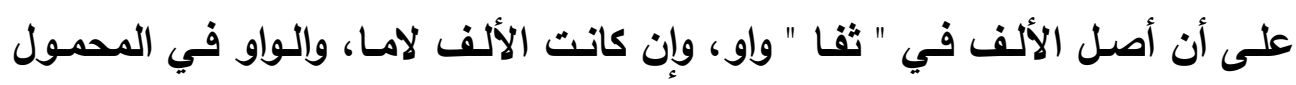

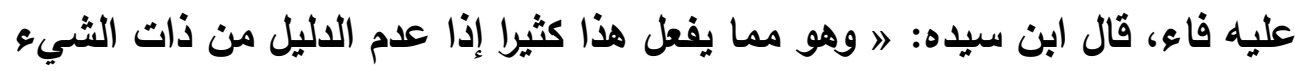

.$^{(0)}$ «

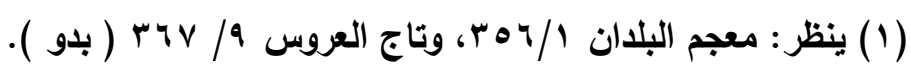

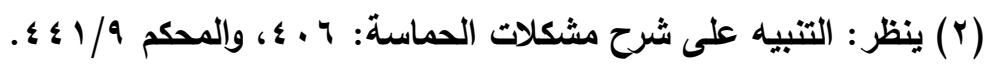

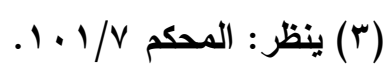

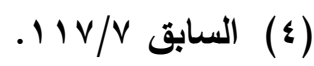

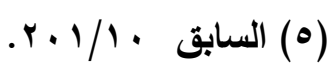


وكذا في " فَنَى "، واحد: الأفناء، وهو: الجهات وإلنواحي، وألفهه مشكلة عند

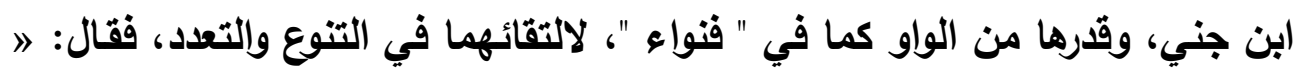

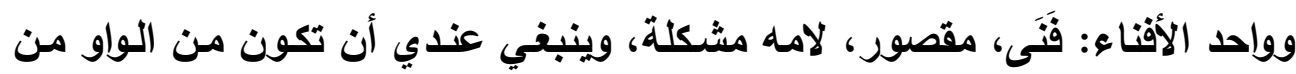

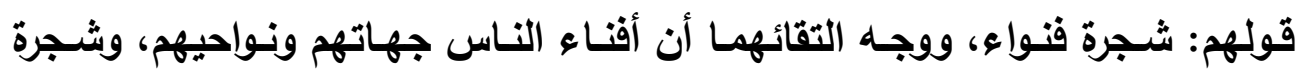

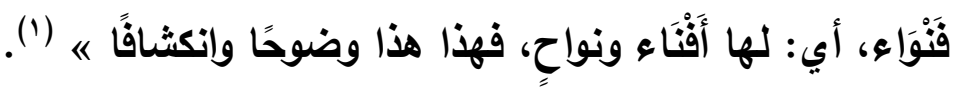

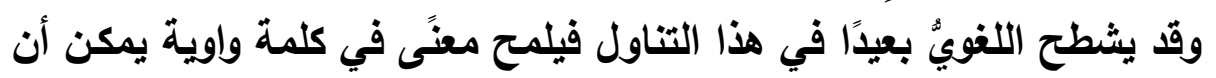

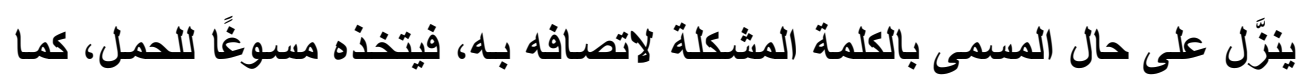

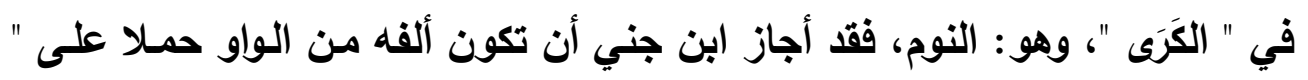

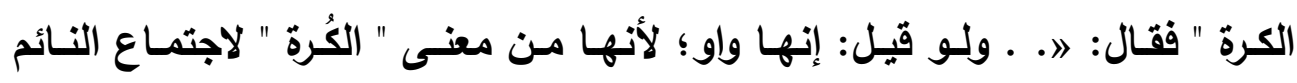

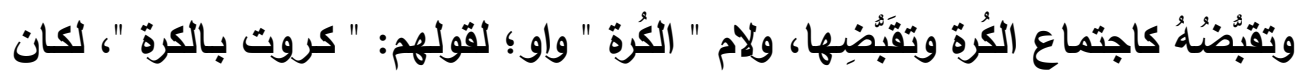

وجها « (ץ)

وأغرب منه حمله ألف " مَها "، وهو : البِّورَ (")، في قول الثناعر:

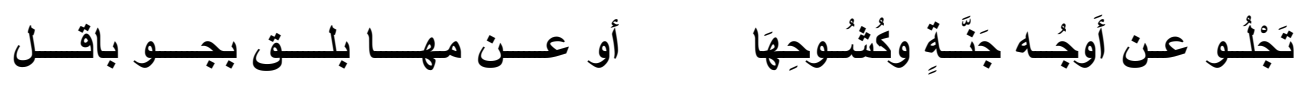

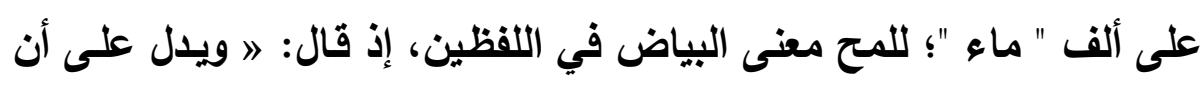

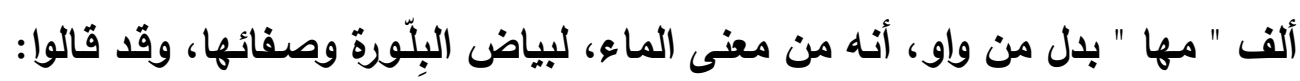

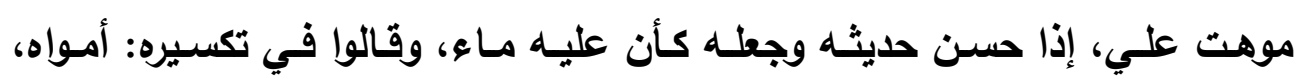

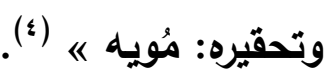

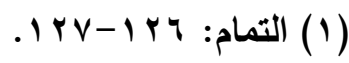

. r०V : السابق

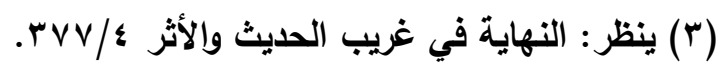

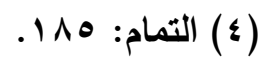


وكذا في " كَرًا "، بمعنى: نقص أو زاد، من الأضداد، ويقال: أكرى الرجل: قلَّ

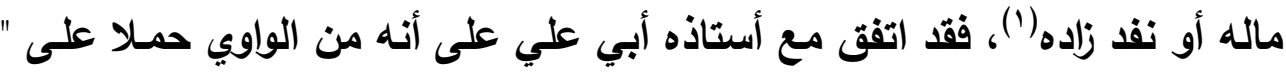

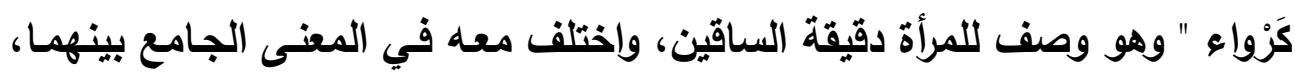
فقال: " وسألني أبو علي - رحمه الله - يوما فقال:

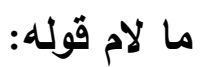

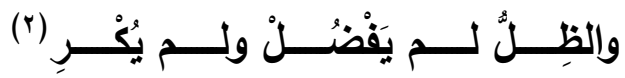

فأخذنا جميعا ننظر فيـه فقـال: هو من قولههم: ( سـاق كَزْوَاء ) لاجتماعها

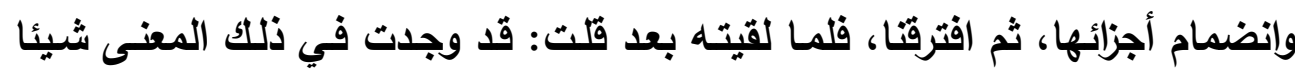

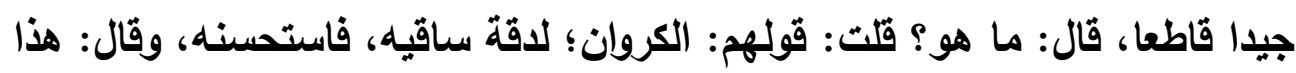

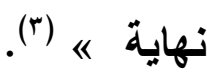

فأبوعلي الفارسي على أن الانحسار والنقص في الظل في معنى الاجتمـاع

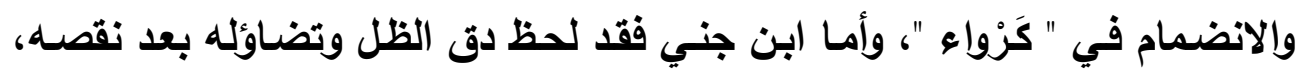

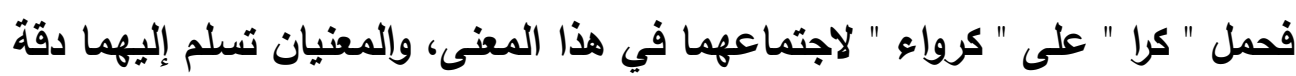

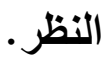

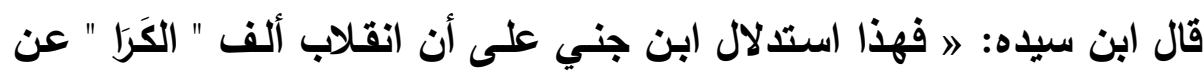

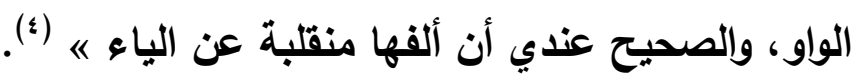

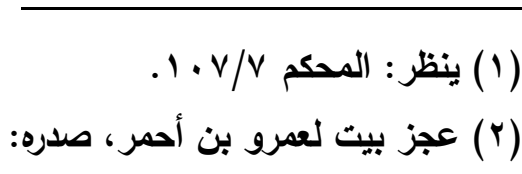
وتوا هقت أخفافها طبقا. . . . . ينظر: شعره: س س 11. rov ( التمام: rov

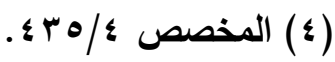




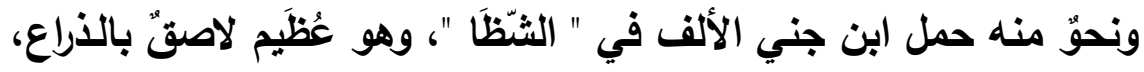

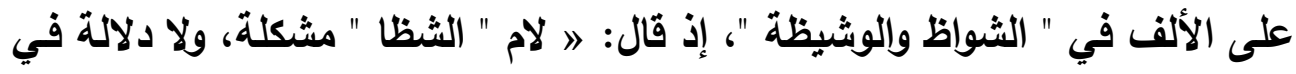

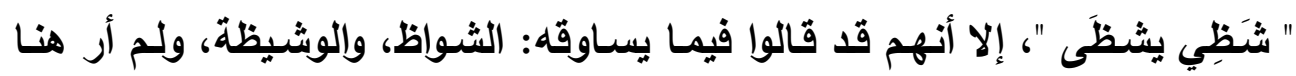

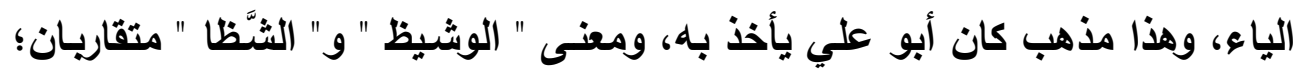

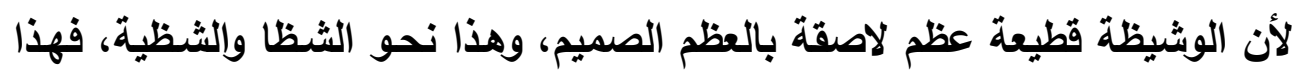

يقوي الواو « (')

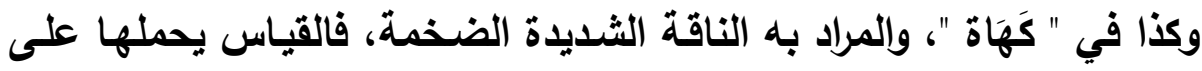

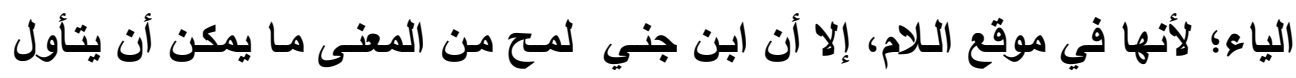

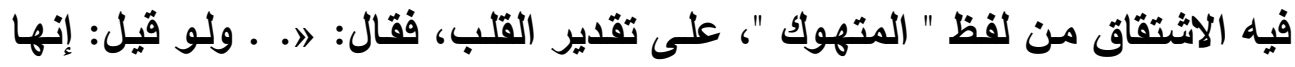

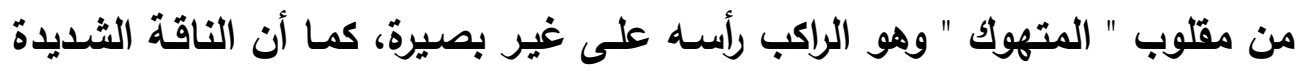

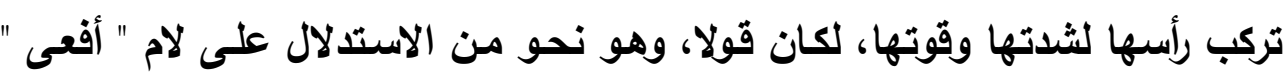

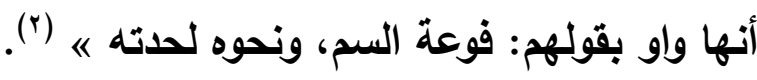

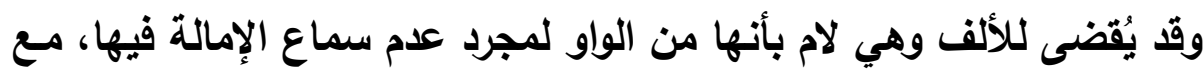

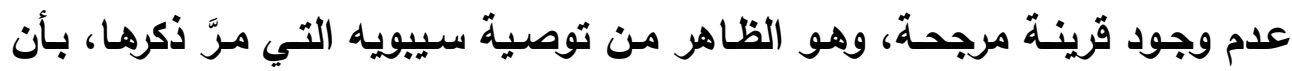

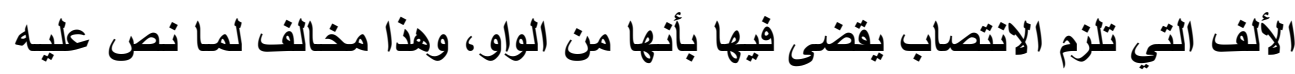

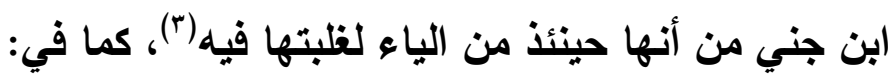

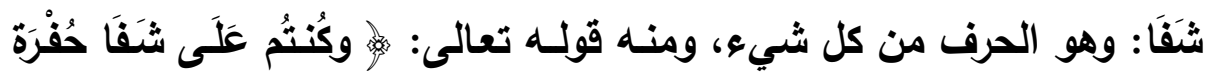

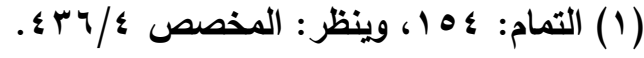

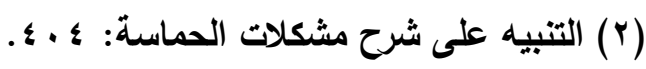

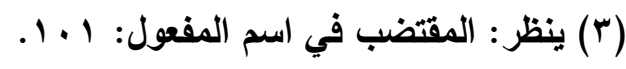

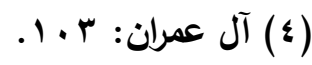


قال الأخفش: » لما لم تجز فيه الإمالة عرف أنه من الواو؛ لأن الإمالة من

لياء

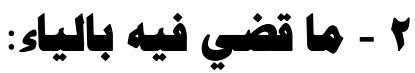

قضـوا لبعض الألفـات المجهولـة الواقعة عينـا بأنها مـن الياء لقرائن،

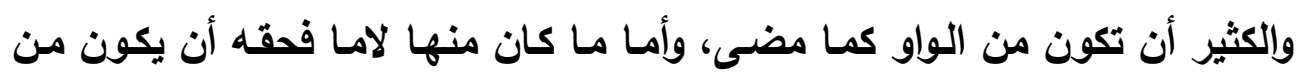

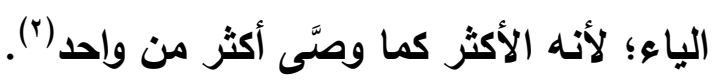
أ - ها كانت الألف فيه عينًا:

لغلبة الواو على الياء فيما وقع من الألفات عينًا، قل مـا قُضِي لـه أنـه

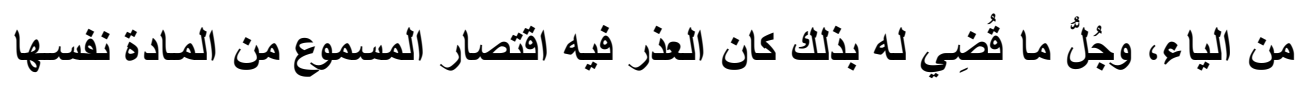
على الياء وإهمال الواوي منها، كما في:

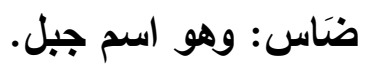

قال ابن سيده: " وقضينا بأن ألفه ياء، وإن كانت عينا، والعين واوًا أكثر منها

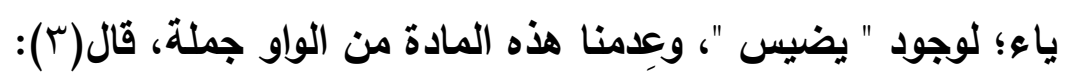

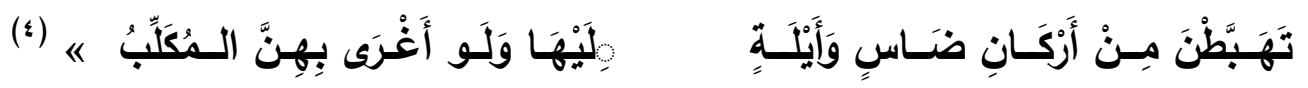

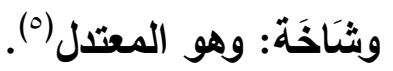

قال ابن سيده: " وإنما قضينا على أن ألف " شَاخَةَّة " ياء؛ لعدم " ش و خ "،

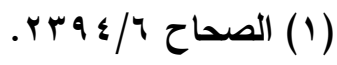

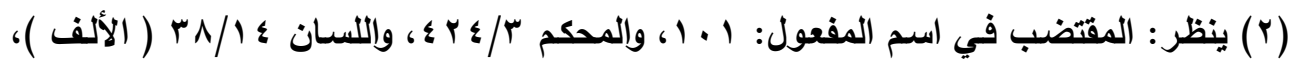

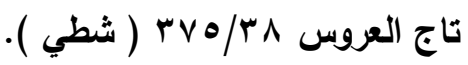

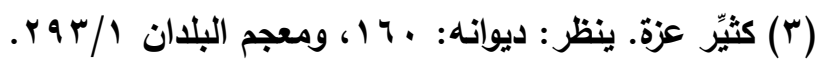

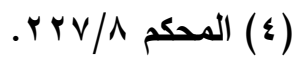
(๑) ينظر : تهذيب الألفاظ لابن السكيت: . 10. 
وإلا فقد كان حقها الواو لكونها عينًا « (').

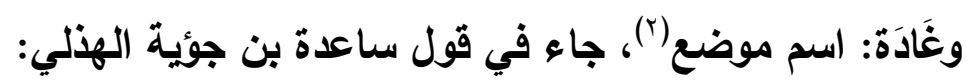

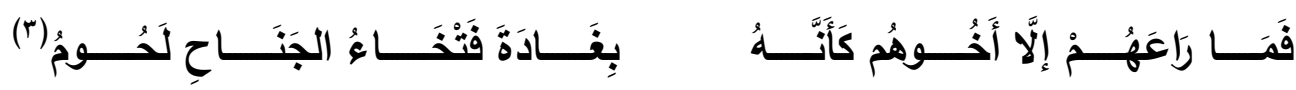

قال ابن سيده : " وإنما حملنـاه على الياء؛ لأنا لم نجد في الكلام " غود "

.$^{(\xi)}$ «

أو يكون استعمال المادة بالياء هو الغالب، كما في:

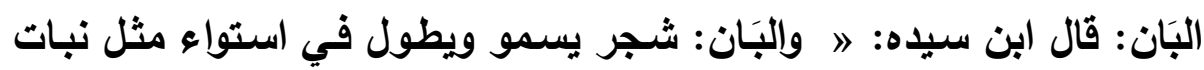

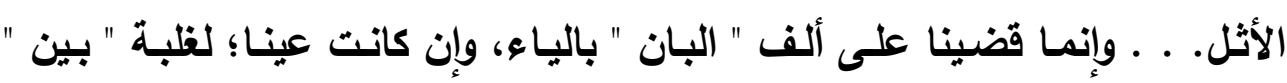

على " بون " ه (०).

وقلما أتكَّئوا على المعنى في حمل الكلمـة المشكلة على كلمة يائية من مادة

أخرى تلثقي معها في شيء من الدلالة، كما في:

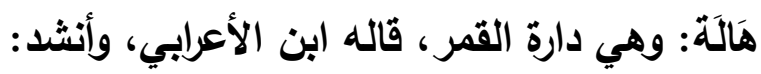

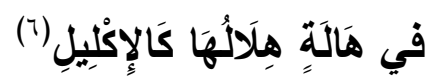

قال ابن سيده: " وإنما قضينا على عينها أنها ياء؛؛ لأن فيها معنى الهَيُول، الأي هو ضوء الثمس. فإن قلت: إن " الهَيول " رومية، والد " هالة " عربية. كانت الواو أولى به؛ لأن

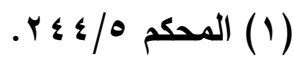

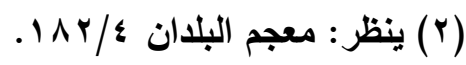

$$
\begin{aligned}
& \text { ( ) المحكم 9/7. }
\end{aligned}
$$

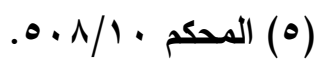

$$
\begin{aligned}
& \text { (7) ينظر: البارع في اللغة: 1. 1. 1. }
\end{aligned}
$$


انقلاب الألف عن الواو وهي عين أكثر من انقلابها عن الياء، كمـا ذهب إليه.

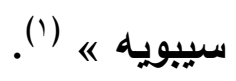

\section{ب - ما كانت الألف فيه لاهما:}

مر قبل أن الألف إذا كانت لامـا فحقها أن تكون من الياء، حمـلا

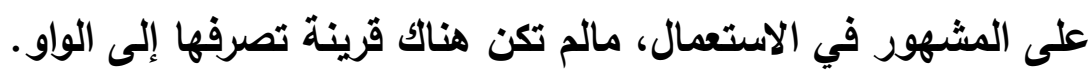

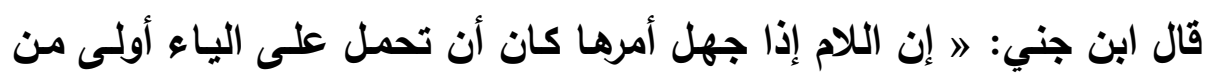
أن تحمل على الواو؛ وذلك لأن التلام موضع تقلب فيهـ الواو في كثير من الأحوال

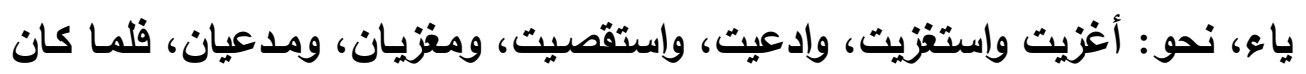

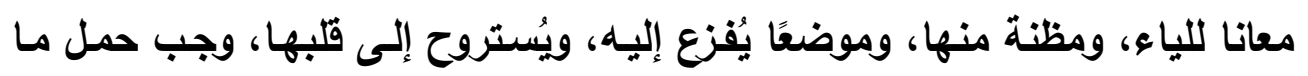

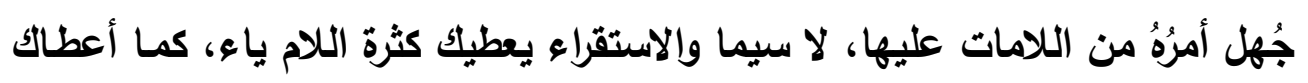

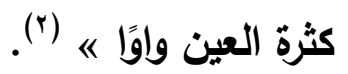

ومما قُضِي لألفه من الأسماء بالياء مـع عدم وجود قرينة مرشحة لها غير

كونها لامًا:

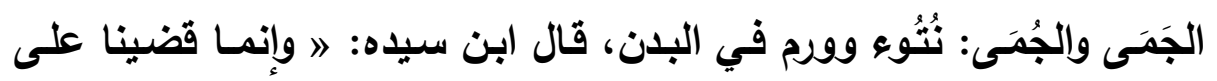

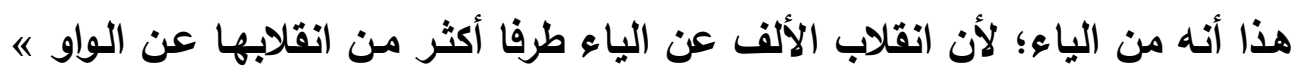

والحَجَاة: نفاخة الماء من قطر وغيره(ء).

(1) (1) المحكم \&/Y (1)

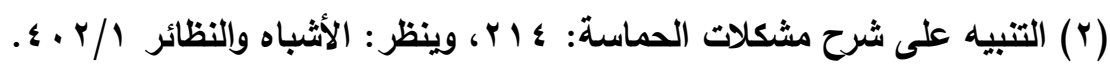

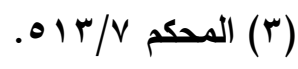

( ) السابق 
حمله ابن سيله على الياء قائلا: \ لأنـا لا نعرف من أي شيء انقلبت ألفه،

فجعلناه من الأغلب عليه وهو الياء، ويذلك أوصانا أبو علي القارسي « (').

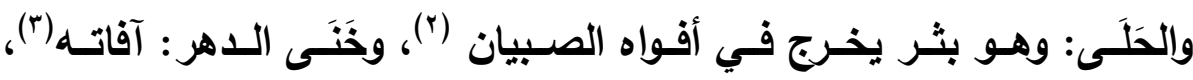

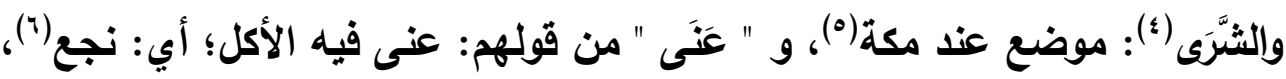

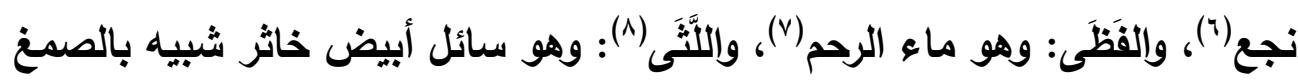
بالصمغ يفرزه شجر الثمام(9)، واللَّجَى: وهو ذكر الضفادع(·')، واللََََّى: وهو كثرة

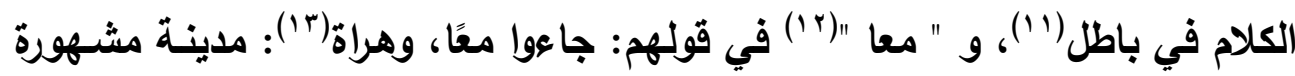

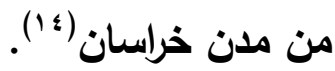

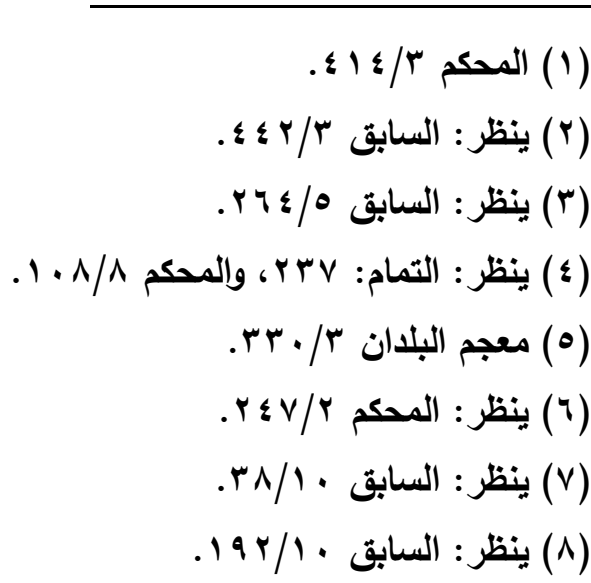

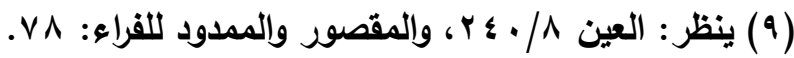

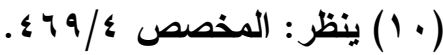

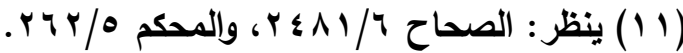

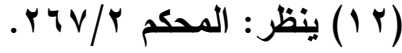

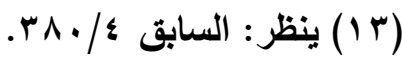

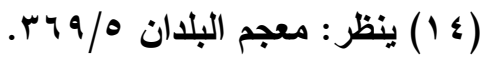




\section{ومن الأفعال:}

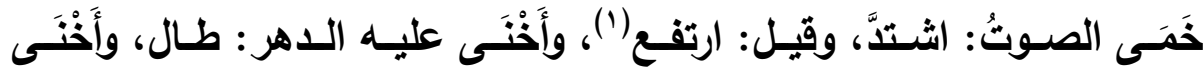

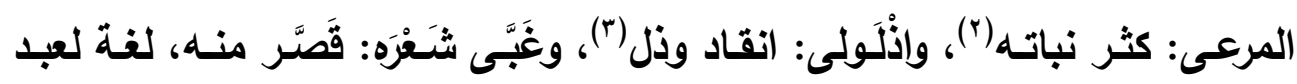
القيس، وتكلم بها غيرهم (4). ويظهر أن حمل الألف المجهولة الواقعة لامًا على الياء في غياب القرينة من فن

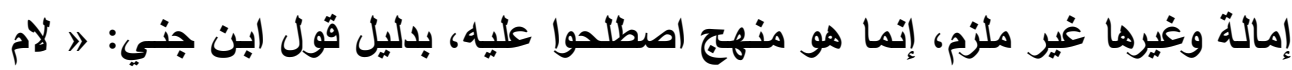

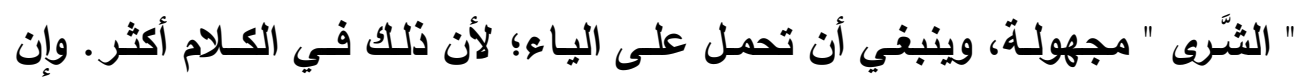

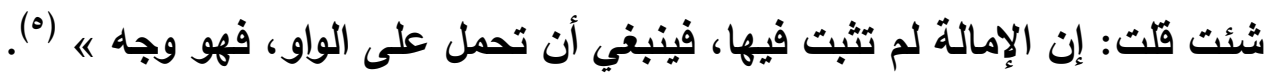

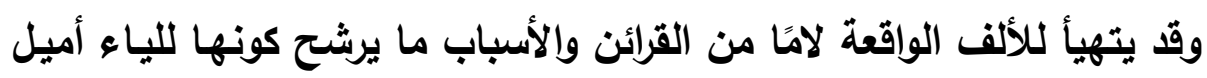
غير كونها لامًا، منها: الإمالة: قال سييويه: ״ فإذاذا جاء شيء من المنقوص ليس لـه فعل تثبت فيه

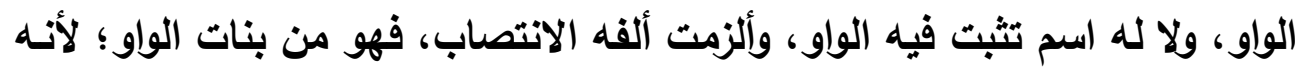

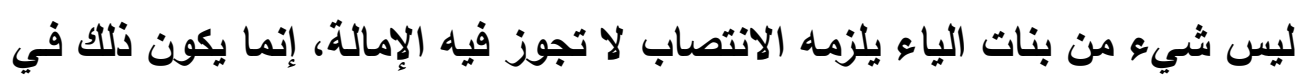

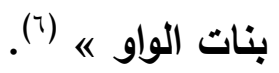
ومما استدل فيه بالإمالة مع وقوع الألف لاما:

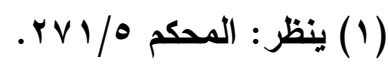

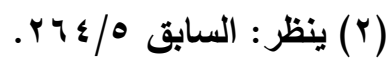

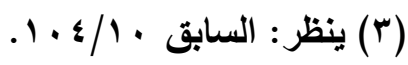

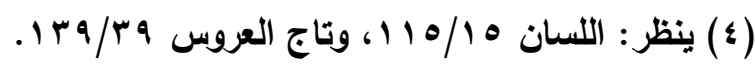

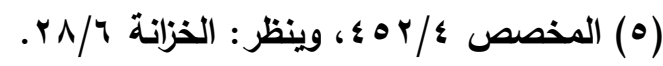

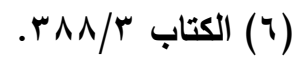




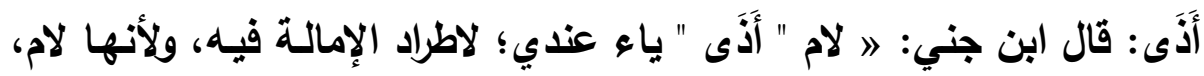

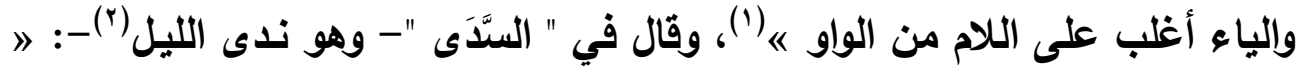

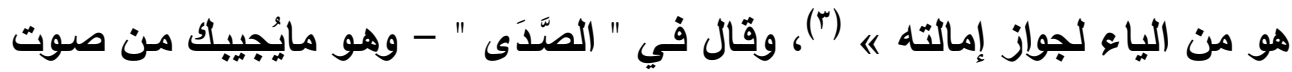

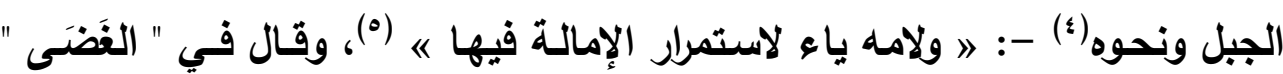

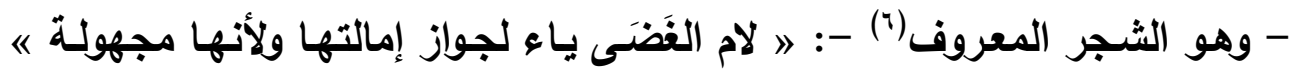

$$
\text { (v) }
$$

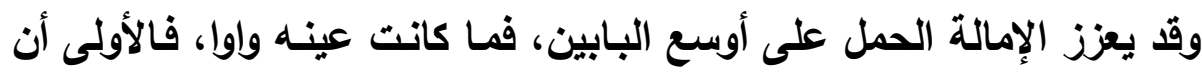

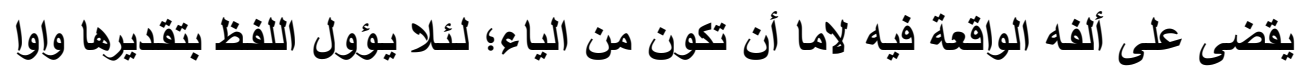

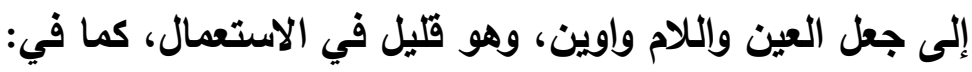

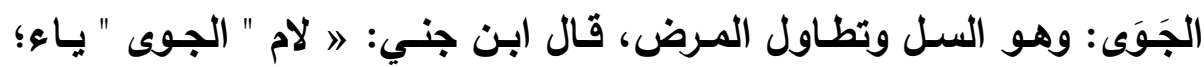

لجواز إمالتها، ولأن العين واو فيها هـ (9.).

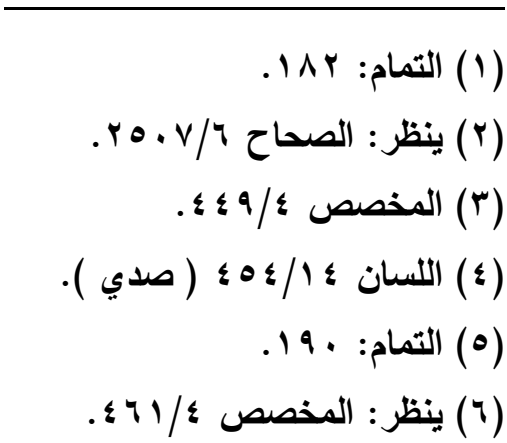

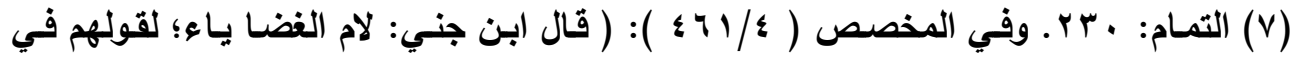

فعلاء منه: الغضياء ).

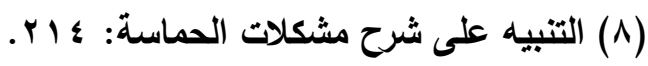

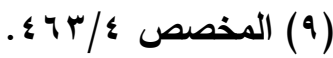


- اقتصار المسموع من المادة على الياء:

وهو من الأدلة التي احتكم إليها ابن سيده كثيرًا في حمل الألف الواقعة لامـا على الياء، ومما قضى فيه بذلك:

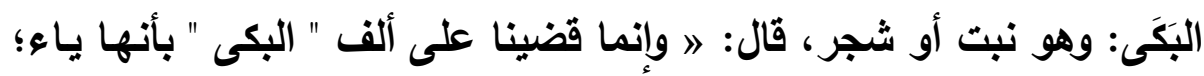

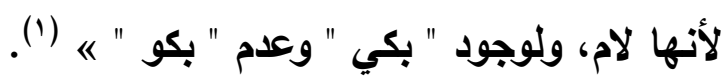
وشَطَّا: بلدة في مصر تتسب إليها الثياب الثطويةِ(؟)، قال: " وإنما قضينا بأن ألف " شَطًَا " ياء؛ لكونها لاما، والـلام يـاء أكثر منها واوا، مـع وجود " شطي "

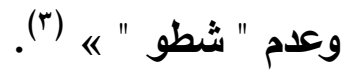
والأََْْفَى وهو المثقب، قال: " وإنما قضينا بأن ألف " الأشفى " ياء؛ لوجود " شفي " وعدم " شفو " " (؛)

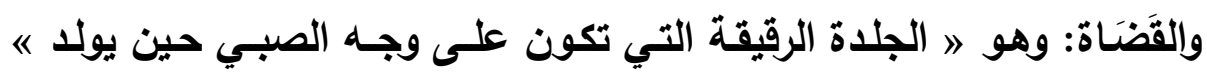

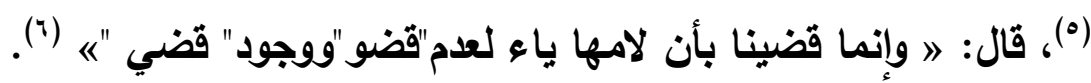
- كثرة المسموع من المادة بالياء:

\section{ومنه:}

الطنَّى: وهو اللذة؛ قال أبو صخر الهزذلي:

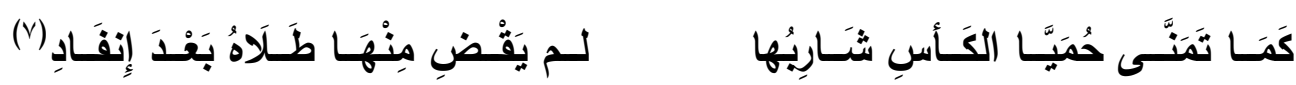

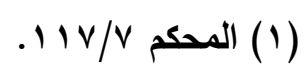

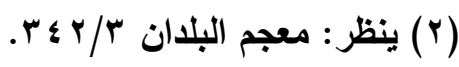

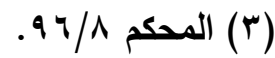

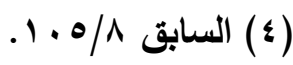

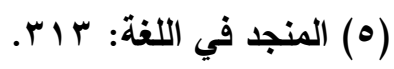

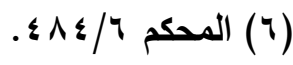
شـ (V) 
قال ابن سيده: " وإنما قضينا على " الطلى " الذي هو اللذة بالياء، وإن لم

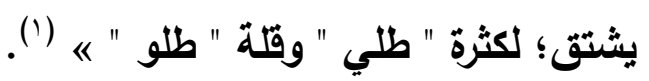

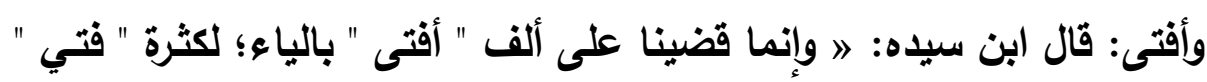

وقتة " فتو " ه (r).

وقد يتمسك بالياء وإن كانت المادة بالواو أكثر حمـلا على أوسـع البابين؛ لأن

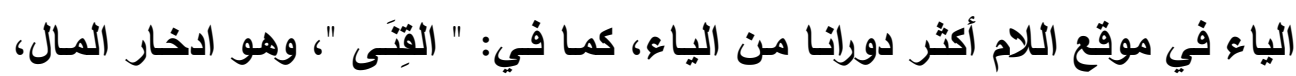

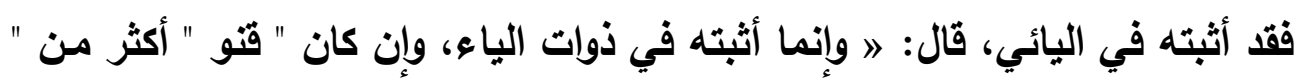

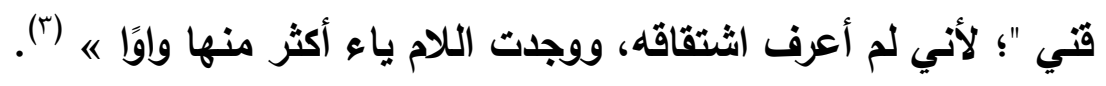
- تحاشي عدم النظير:

كما في " الجيَّا " وهو: بيوت الزينابير، فقد حمله ابن سيده على الياء؛

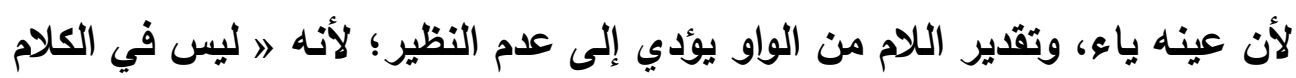
ما عينه ياء ولامه واو " (ء). وقد لا تسعفُ الصنعةُ اللغويَّ في تقدير ما يمكن أن تؤول إليه الألف من واو

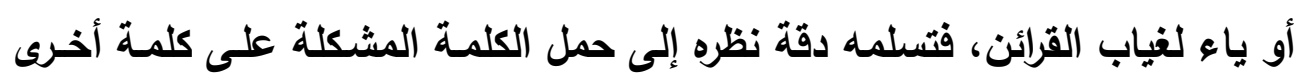

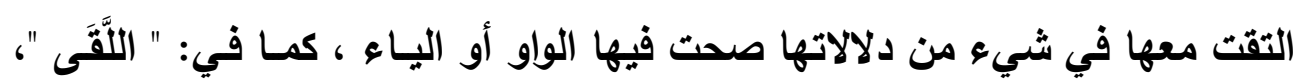

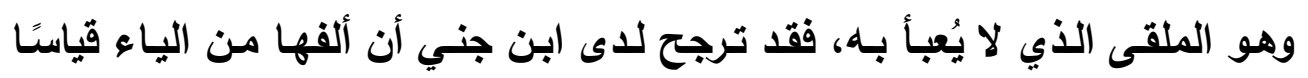

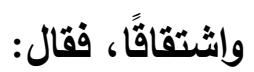
" أما القياس: فلأن اللام إذا كانت حرف علة، وأعوزت الأدلة في بابها من

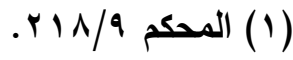

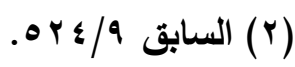

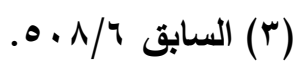

$$
\begin{aligned}
& \text { ( ) المخصص \& \& \& }
\end{aligned}
$$


ضروب تصاريفه، حكم بأنها ياء؛ وذلك لظلبة الانقلاب إلى الياء في موضع اللام. .

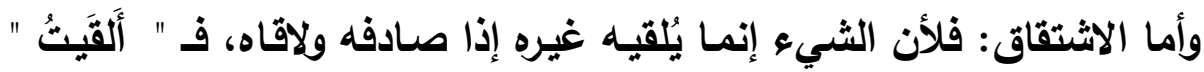

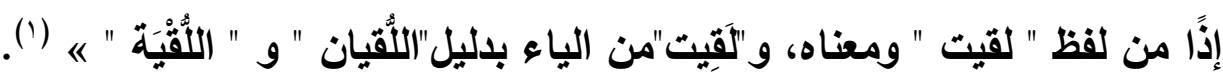

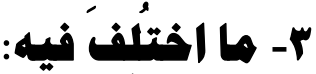

قد يُختلف في تقدير ما تؤول إليه الألف المجهولة لاختلاف مـا برد في اليد من قرائن، ولكلٍّ مقادُه وصنعته، ومما لم تجنمع عليه كلمتهم من ألفات:

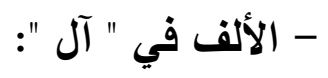

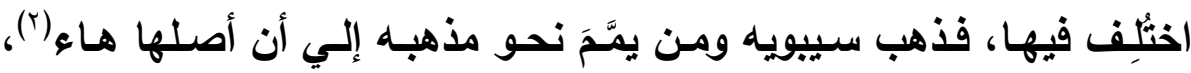

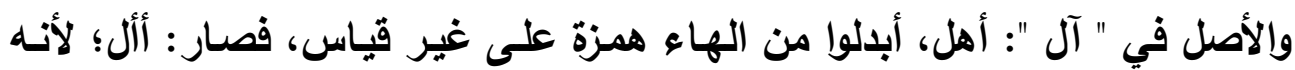

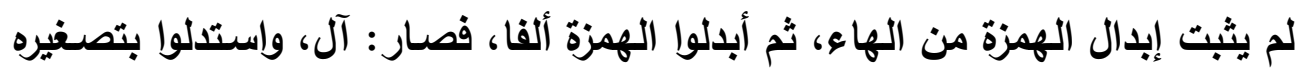

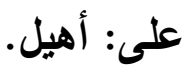

وذهب بعضهم إلى أنها مجهولة، وحملوها على الواو؛ لأنها عين (").

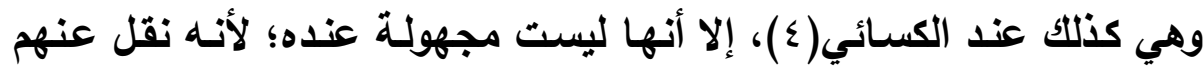

أنهم صغروا " آل " على: أويل، ف " آل " مشتق من: آل آل يؤول.

- الألف في " بَانَّة ": إينا

البانة: 》 شجرة لها ثمرة تربب بأفاويسه الطيب " (०)، وألفها مجهولـة،

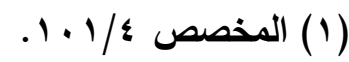

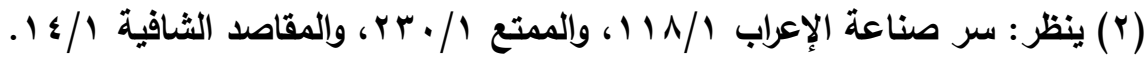

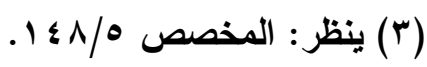

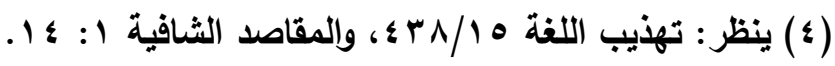

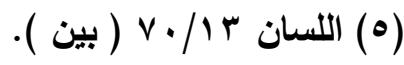


وقد قضى عليها ابن جني بأنها من الواو؛ لعدم ظهور اشتقاق لها، فقال: 》 عين "

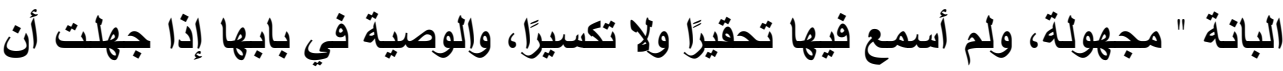

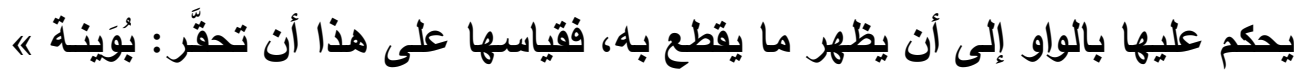

وخالف ابن سيده وجعلها من الياء؛ حملا على المشهور في الاستعمال؛

لأن " بين " غالب على " بون "(r).

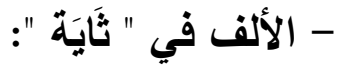

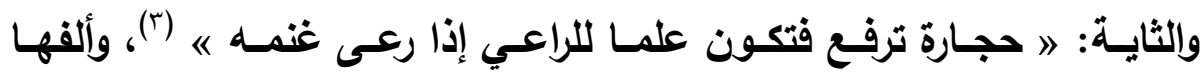

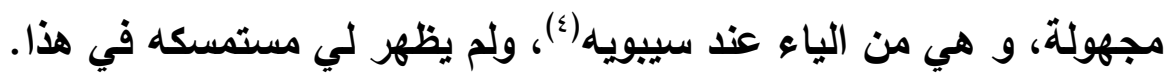

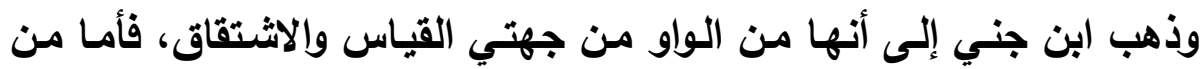
جهة القياس: فإن الألف إذا كانت عينا فحقها أن تكون واوا حملا على الغالب.

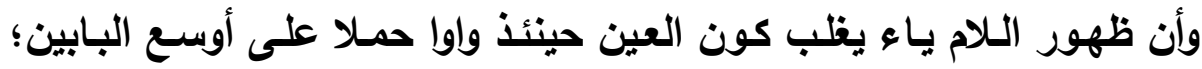

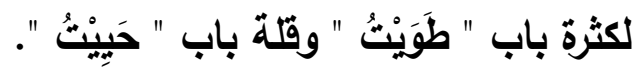

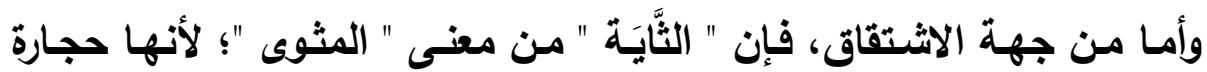

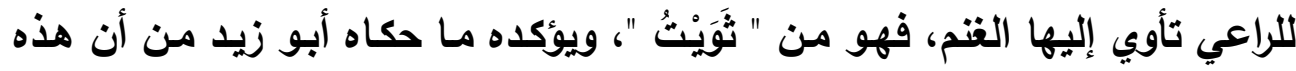

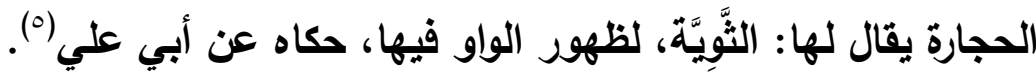

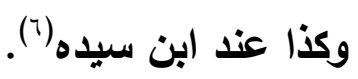

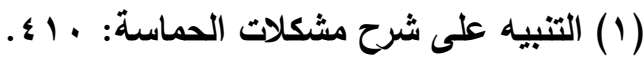

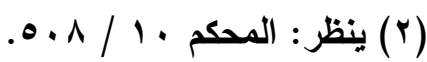

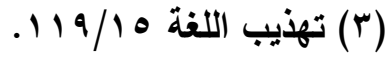

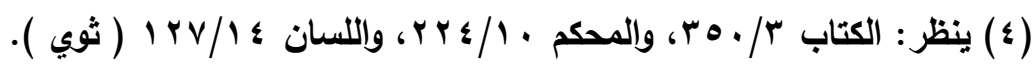

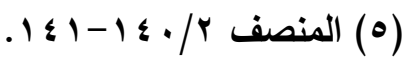

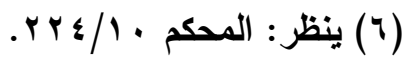




\section{- الألف في: حَاحَيث وعَاعَيث وهَاهَيت:}

وهي أفعال مبنيـة من أسماء أصوات لزجر الإبل وغيرهـا، قال الأخفش: الـم

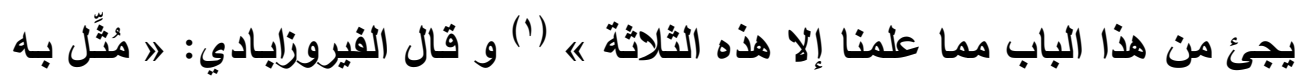
في كتب التصريف، ولم يُفَسَّر " (؟)، ولعله لم يقف على قول ابن جني في حديثه

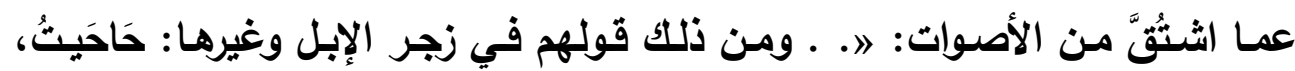

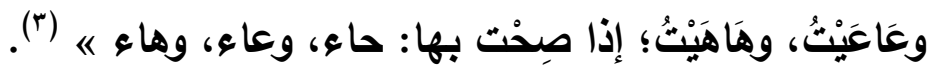
وألفـات هذه الأفعال ممـا جُهِل أصـله؛ لأن هذه الأفعـال مشـتقة مسن أسـماء أصوات على زنة فَعْلَلُْ، وأسماء الأصوات مبنية، ولا يُعرف أصلُ ما فيها من ألفات كما تقدم، لذا اختُلْفَ فيها: فالخليل وسييويه على أنها من الياء(؛)، وذكر ابن السراج إجماع البصريين

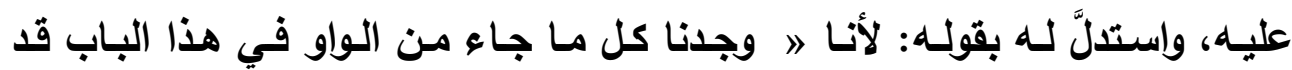

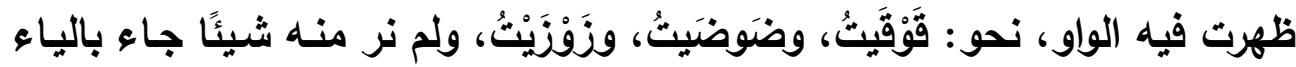

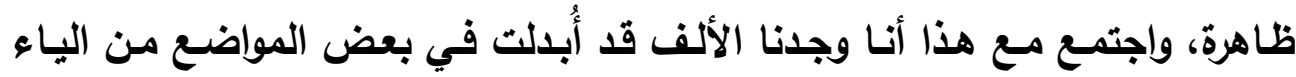
السـاكنة، ولم نجدها مبلدة من الواو السـاكنة، وذلك قولهم في " طيِّه ": طائي، وإنما هو: طيئي، فقلبوا الياء ألفًا. . . « (•).

\section{(1) - (1) الأصول 11/r)

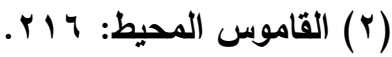

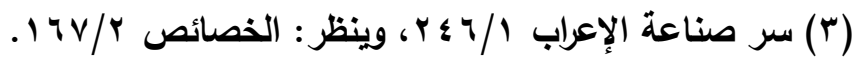

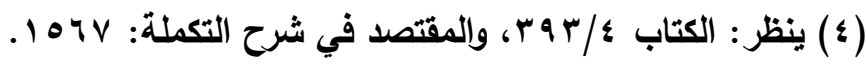

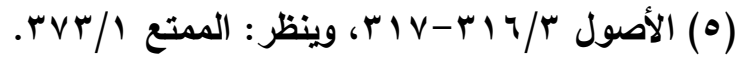


والقياس كما ذكر بقاء الياء، كما بقيت الواو في " قَوقََيت"، ولكنهم تجنبوا ذلك

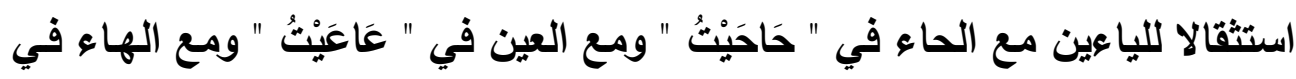

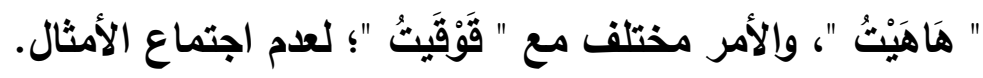

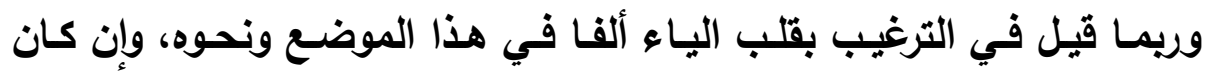

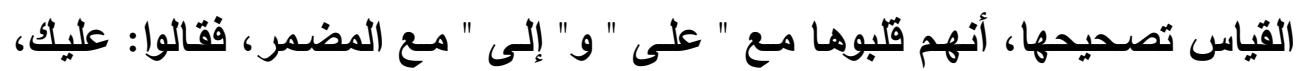

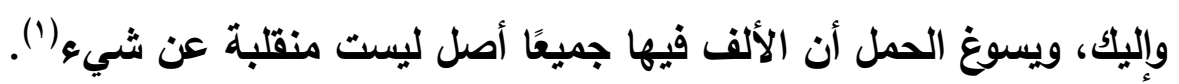

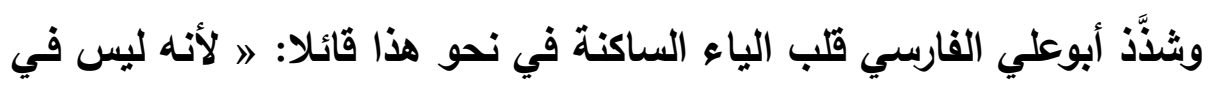

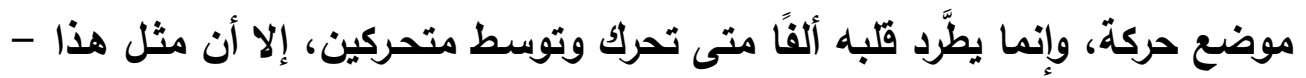
أيضا - قد يجيء نادرا ه (`) وذهب المازني إلى أن الألف من الواو حمـلا على " قَوَقَيَنَُّ "؛ لأنها لم ينطق لها بأصل، فحملت على ما له أصل (").

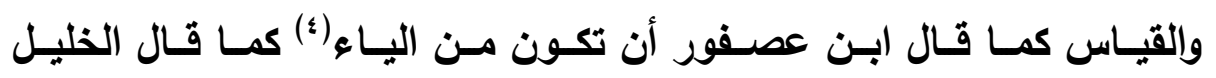

والجمهور؛ لأن الألف أثبه بالياء وقريبة منها (ه).

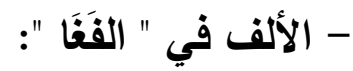

الفَغَا: داء(")، وألكفه من الياء عند ابن سيده؛ لأن الألف إذا وقعت لامـا فإنها

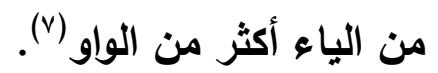

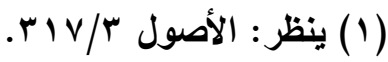

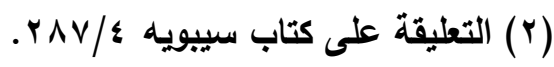

$$
\begin{aligned}
& \text { (؟) ينظر : الممتع (Y) }
\end{aligned}
$$

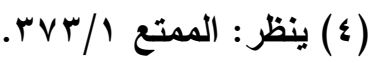

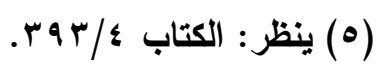

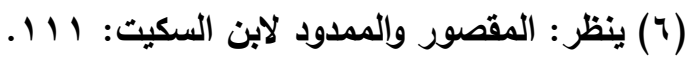

(V) 


\section{وارتضى الزبيدي جواز أن تكون من الواو والياء(").}

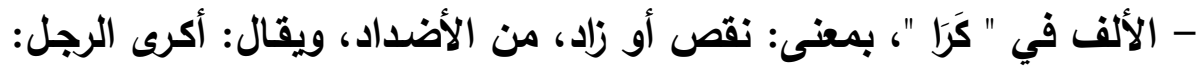

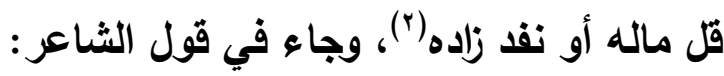

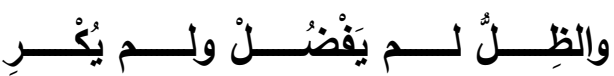

وقد تسـاءل أبو علي الفارسي وتلميذه ابن جني عن مرجع ألفـه، فاستقر

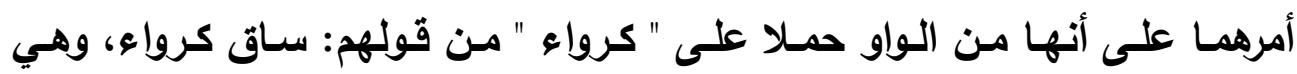

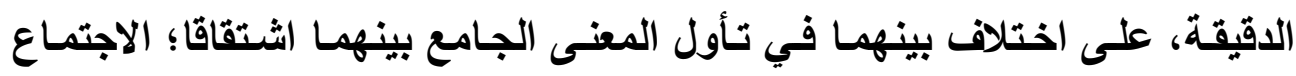
والانضمام، أو الانحسار والتضاؤل (").

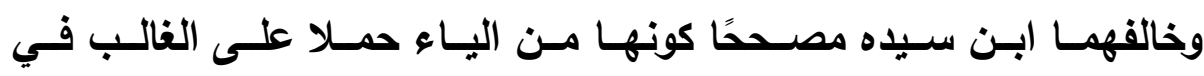

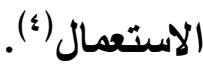

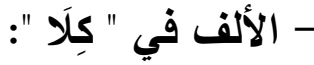

الألف في " كلا " مما لم تجتمع كلمتهم في أصلها ومتحولها على مذاهب:

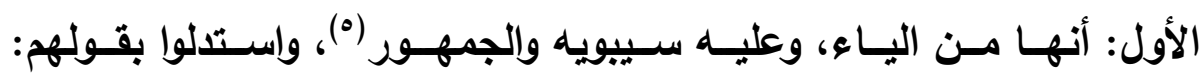

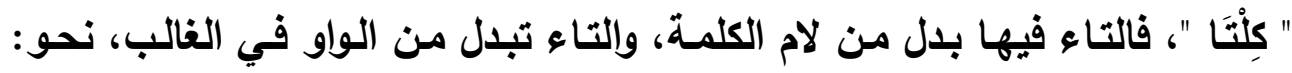

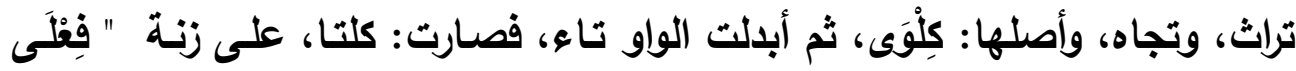

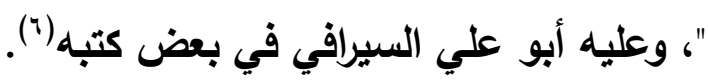

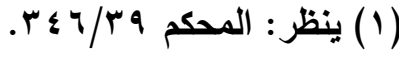

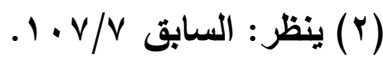

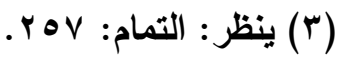

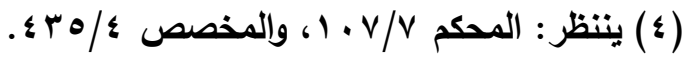

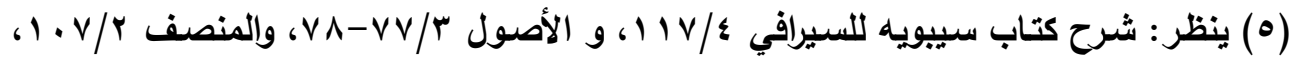

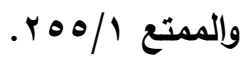

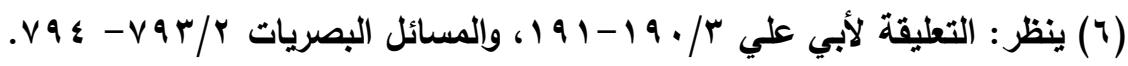


والثاني: أنها من الياء، وعليه أبو علي القارسي محتجا بجواز إمالتها، قال:

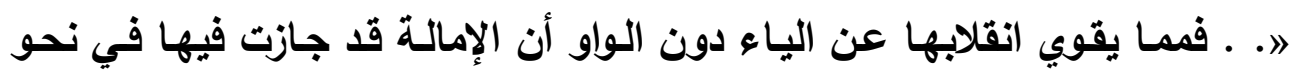

قوله:

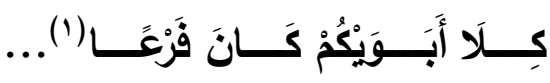

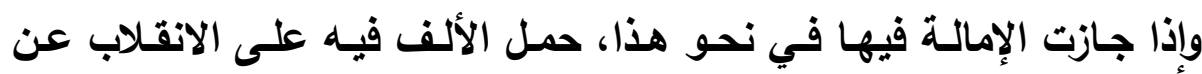

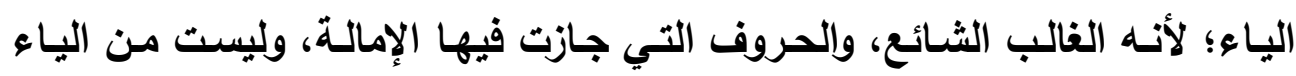

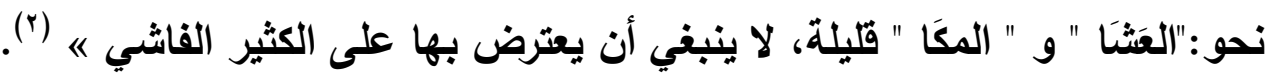

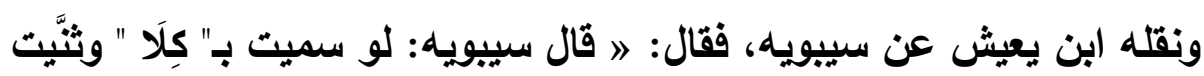

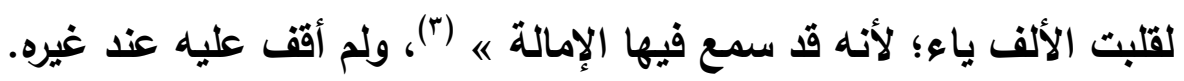

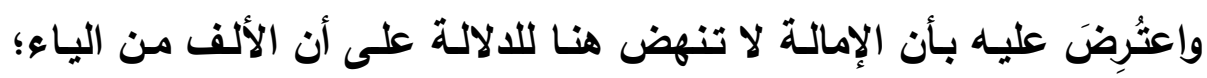

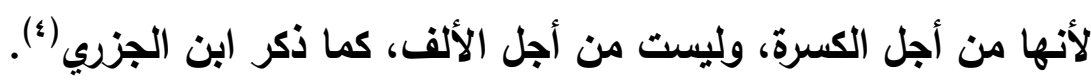

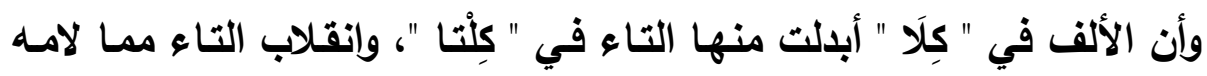

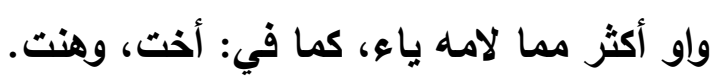

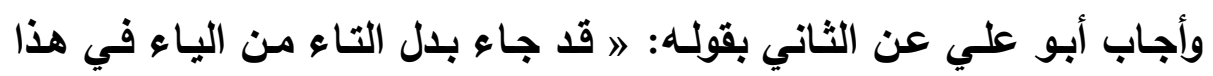

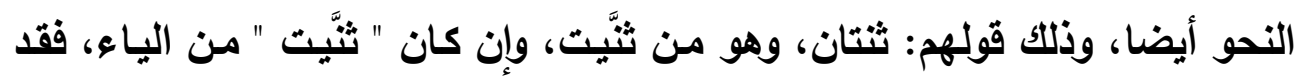

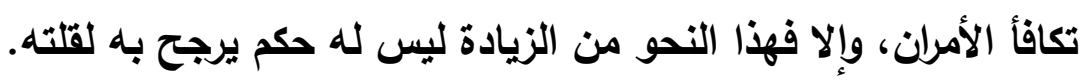

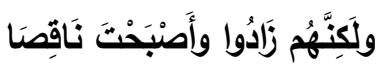

(1) - (1) قطعة من بيت للأعشى، تتمته:

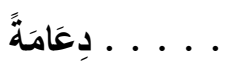

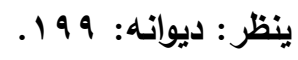

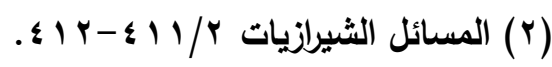

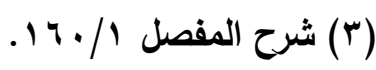

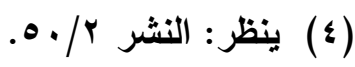


ويقوِّي انقلاب هذه الألف عن الياء أنها قد أبدلت في قولههم: كَيْتَ وكَيْتَ،

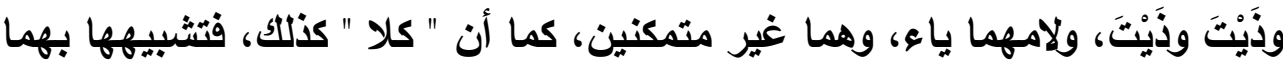

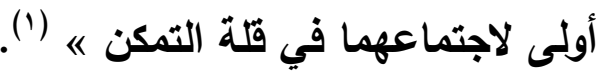

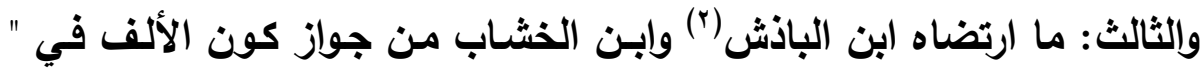

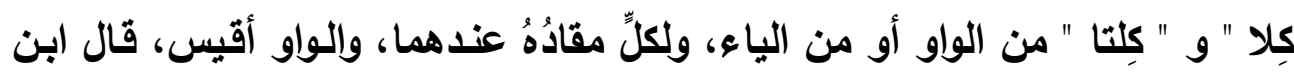

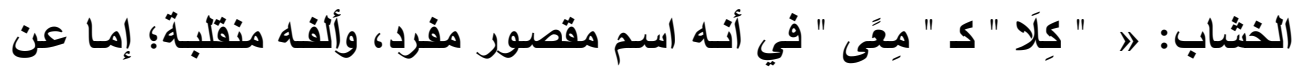

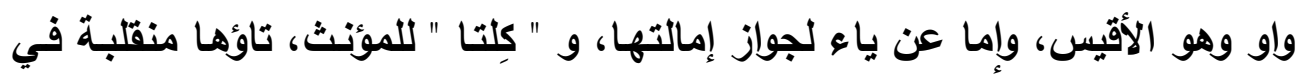

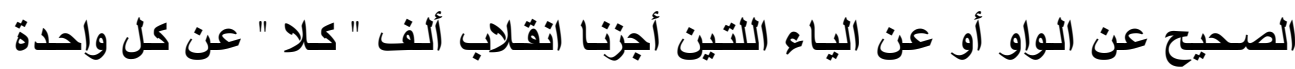

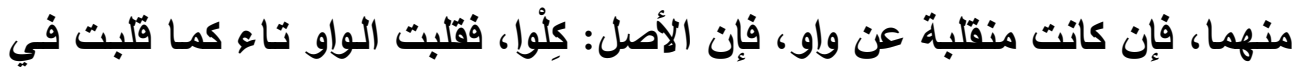
" تُراث "، والأصل: وُراث، و " تُجاه "، والأصل: وُجاه.

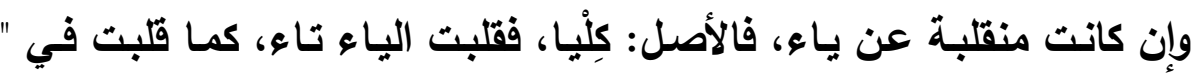

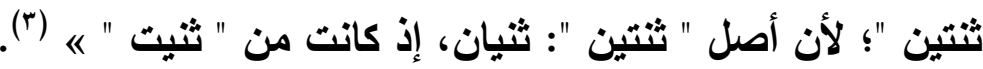

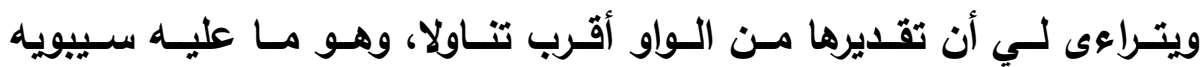
والجمهور؛ لأن انقلاب التاء من الواو أكثر من انقلابها من الياء.

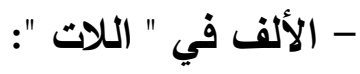

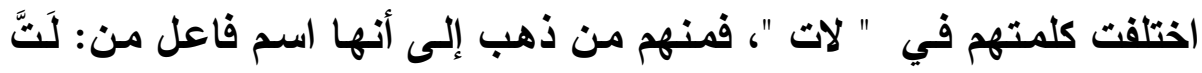

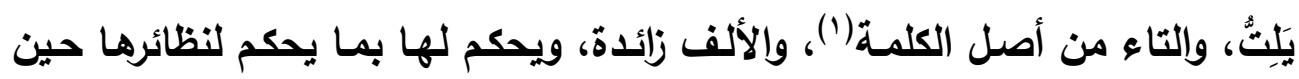

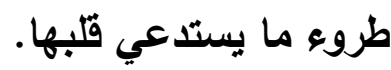

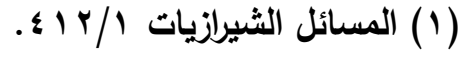

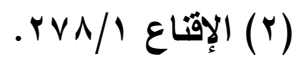

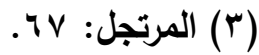


وذهب أبو علـي الفارسـي إلـى أن " الـَّلَت " مشَق مـن: لَوَيْتُ؛ لأنهم كـانوا

يلوون على آلهتهم ويعطفون عبادة لها، وتقريًا إليها.

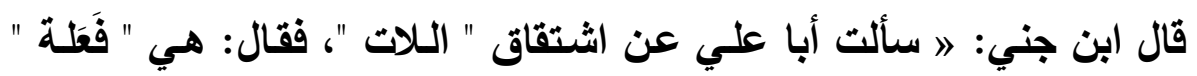

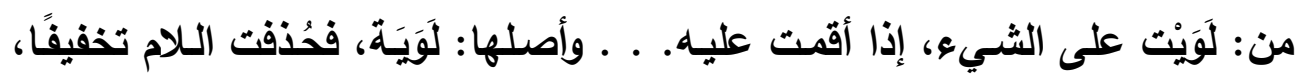

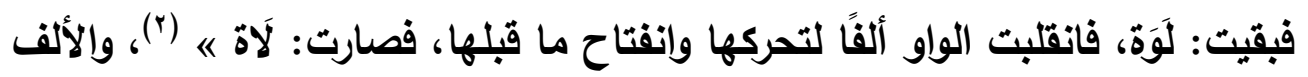
على هذا مبلية من الواو.

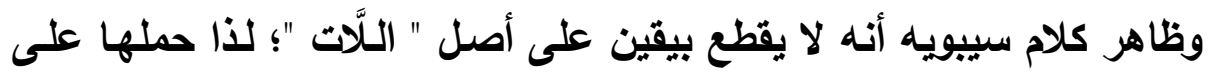

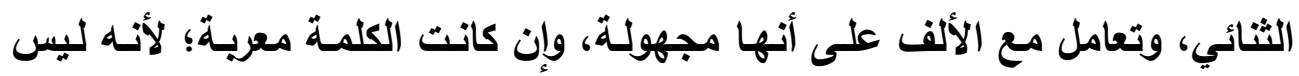

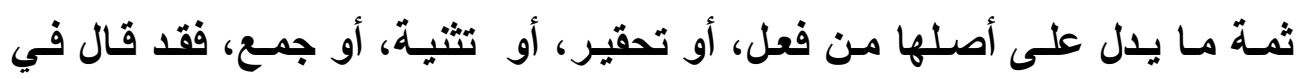

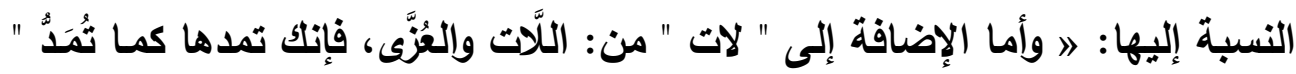

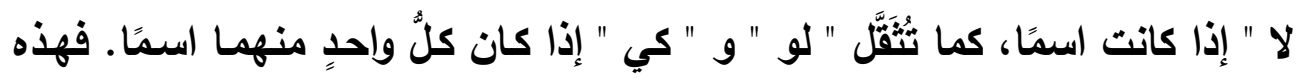

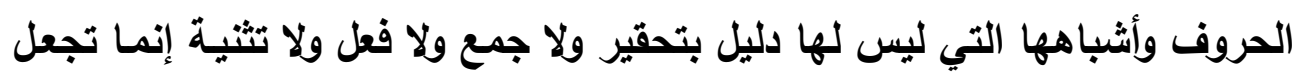

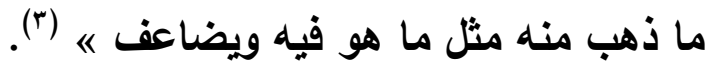

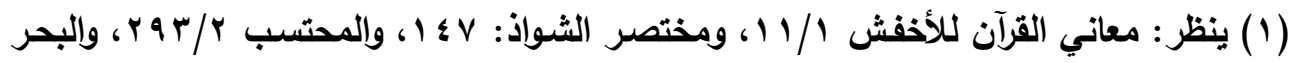

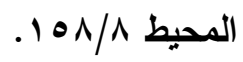

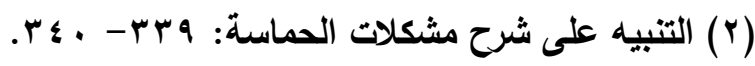

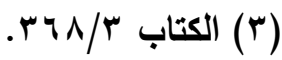




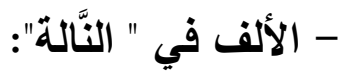

والنَّالة: ماحول الحرم، أو ساحة مكة(')، وألفُها مجهولة؛ لأنه لا يعرف لهذه

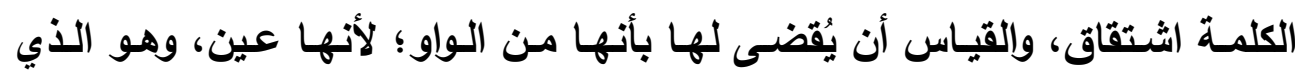
وصَّى به سيبويه كما تقدم، وارتضاه ابن جني مقياسًا فيمـا أشكل أمره من الألفات الواقعة عينا ما لم يجد للاثتقاق طريقا، فهو مولع بالاشتقاق، يستروح إليه، ويتعلل

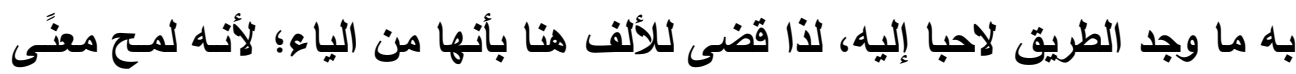

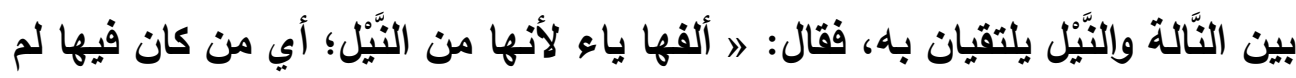

تنله اليا (r)

ولم يَرَق هذا لابن سيده، وآثر جعل الألف من الواو، فقال: 》 وإنمـا قضينا

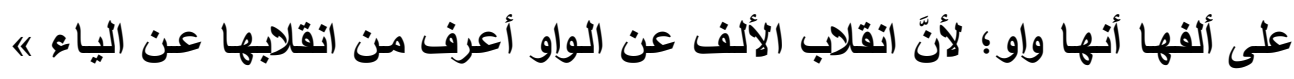

\section{الألف الرزاندة}

وتشمى ألف الصيغة(؛) أو ألف البناء(•)، (وهي ألف تدخل في الأفعال

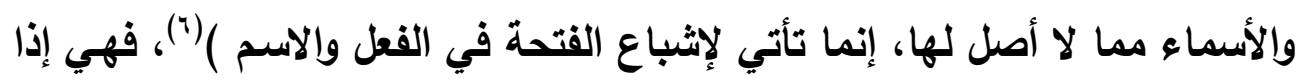

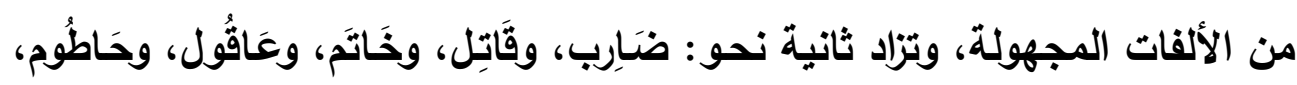

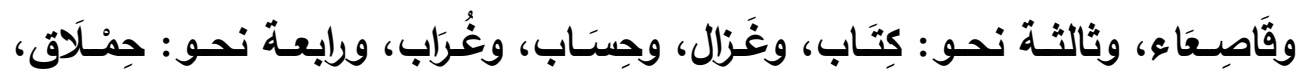

$$
\begin{aligned}
& \text { (1) ينظر : تاج العروس اس//؟ ؟ . }
\end{aligned}
$$

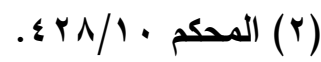

$$
\begin{aligned}
& \text { (r) (السابق نفسه. }
\end{aligned}
$$

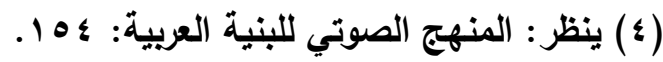

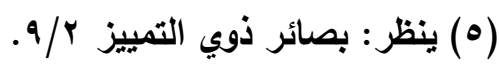

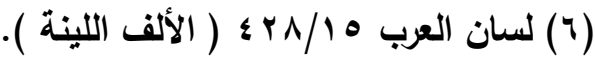




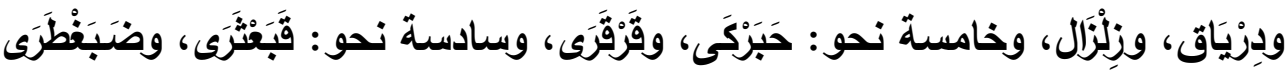

وقد قضوا بقلب هذه الألف واوا عند طروء عوارض التغيير على البنية إن

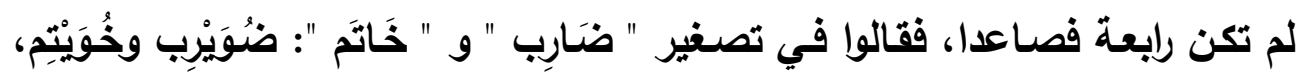

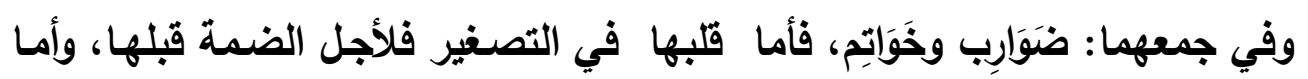

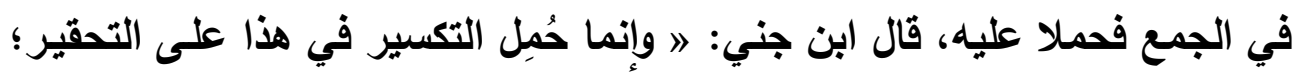

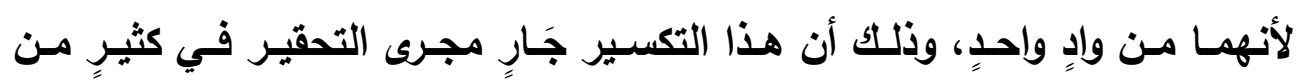

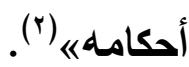

وكذا إذا كانت الألف ثالثة، فيقال في تصغير " كتاب ": كتيب، بقلب الألف

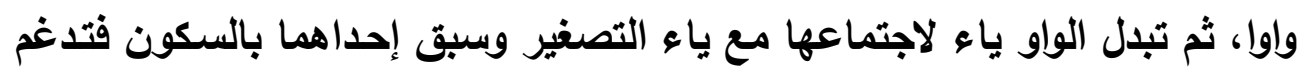

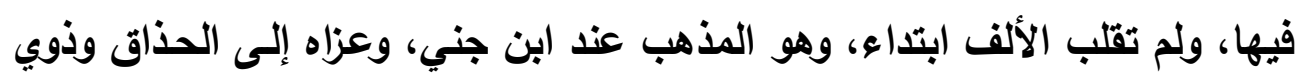

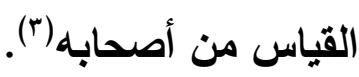
وأما عن عدم قولهم بقلب الألف ابتداء لأجل الياء، كما قلبوها لأجل الكسرة

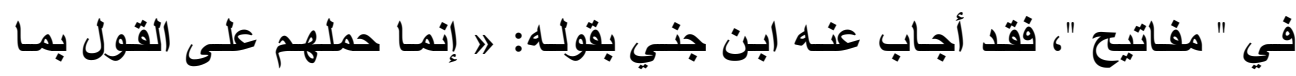

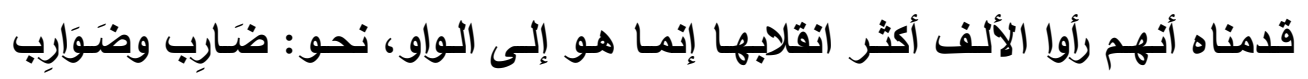

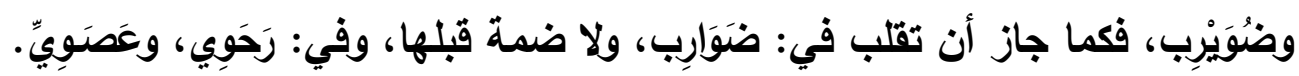

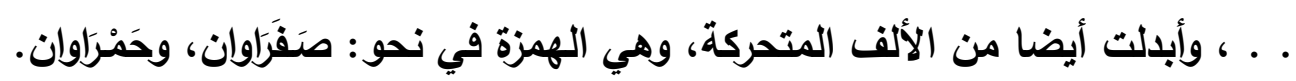

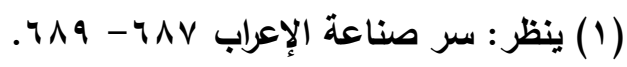

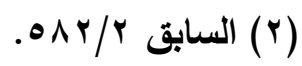

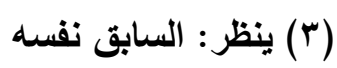


. . كذلك حكما أيضا بأنها في نحو " غَزَلَ " و" غُرَّاب " إنما قلبت في أول أحوالها

واوا « (')

ولم يرتض أحد المحدثين (†) ما يعتقده القدماء بثأن الألف الزائدة، وما يرونه

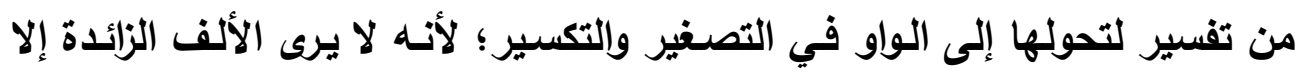

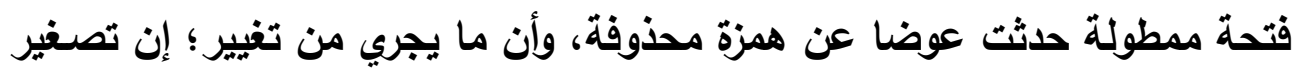

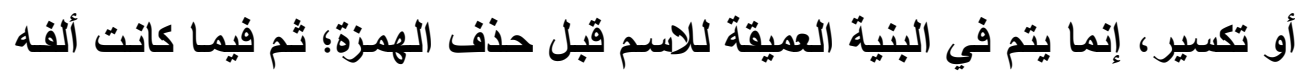

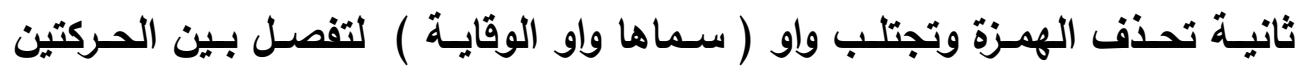

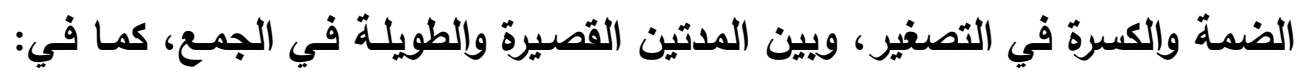

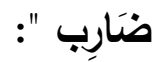

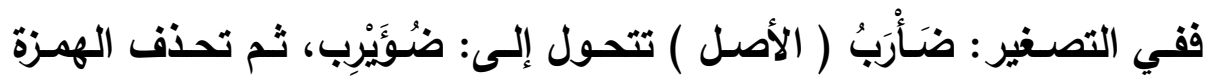

وتجتَب الواو فتصير : ضُوَيْرِب.

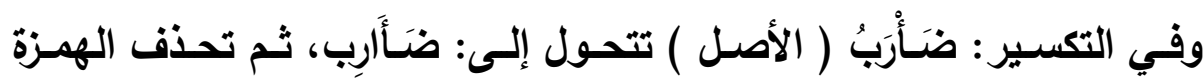

وتجتلب الواو فتصير : ضَوَارِب.

وما كانت ألفه ثالثة كما في "كِتَّب " تحذف همواب هنته عند تصغيره ويعوض عنها بتضعيف الياء، فيكون الإجراء:

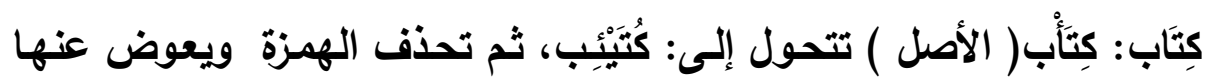
بتضعيف الياء فتصير: كُتَّبِّ.

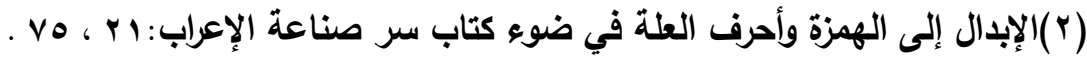


ولتأييا مذهبه في الألف الزائدة وما يطرأ عليها من تحولات، أومأ إلى قصور

في تفسير القدماء؛ إذ لا يتتاول تحول الألف في الجمع؛ لأن ما قبلها مفتوح، وعده

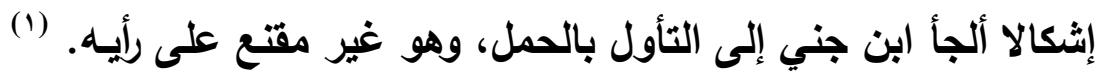

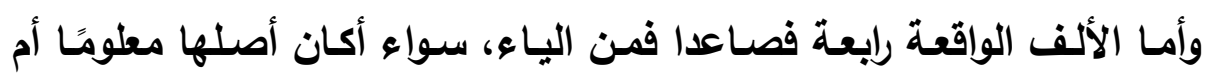

مجهولاً .

وفي توجيه ذلك قال ابن سيده: " وإنمـا وجبت الياء فيمـا زاد على ثلاثثة

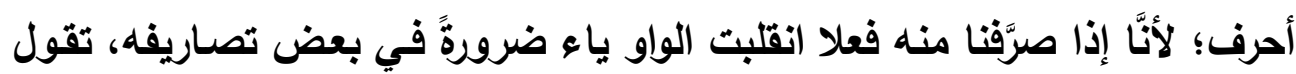

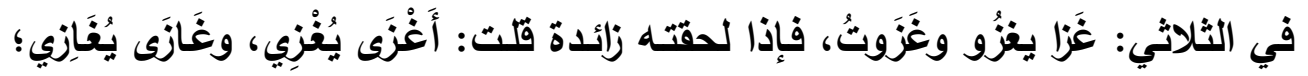

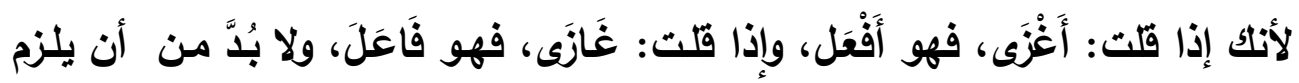

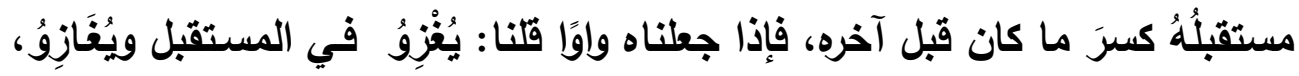

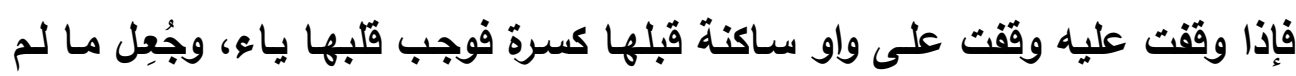

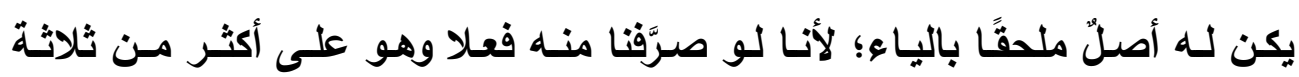

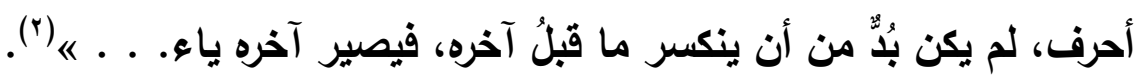

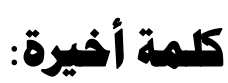

حاول هذا العمل أن يتتبَّع ما قالوه بشأن الألف المجهولة، وما تصالحوا عليه

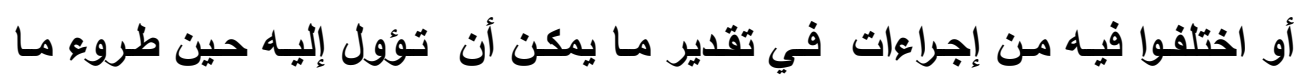

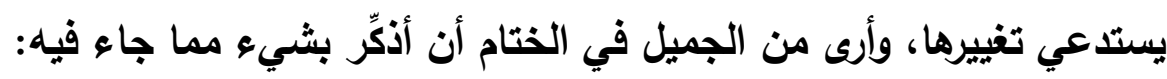

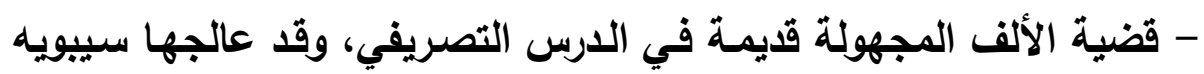
في أكثر من موضع من كتابه.

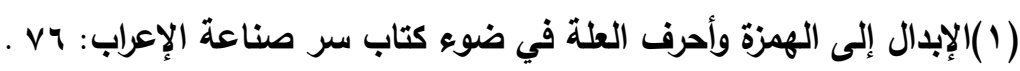

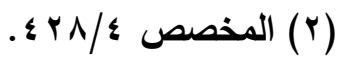


- الألف لا تكون أصلا إلا فيمـا لـ يقض لـه باثتقاق، وهـي فيهله مجهولة، واصطلاح الأصل لها بحسب الظاهر.

- ينضوي تحت الألف المجهولة ما لم يعرف منشؤه من ألفات، سواء كانت الألف أصلية - بحسب اصطلاحهم - أو مبلدة، أو زائدة.

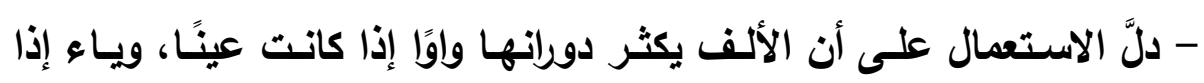

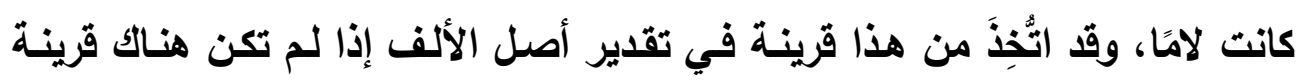
أخرى صارفة.

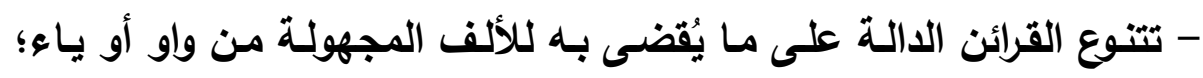

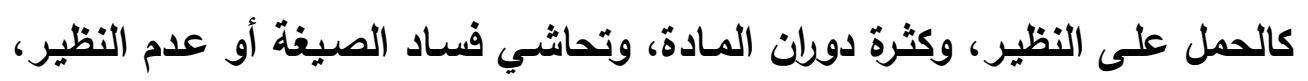
والالتقاء مع مادة أخرى مماثلة في المعنى، وغيرها.

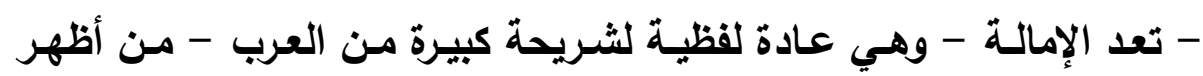

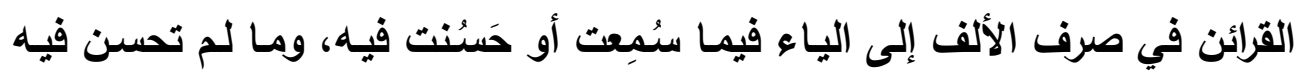

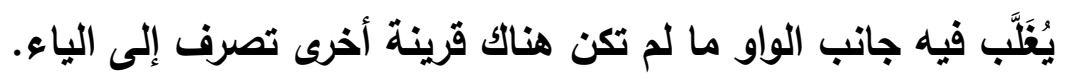

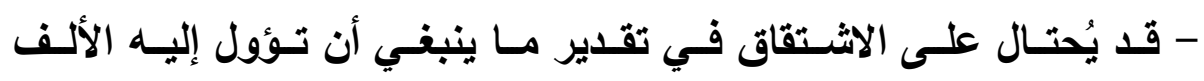

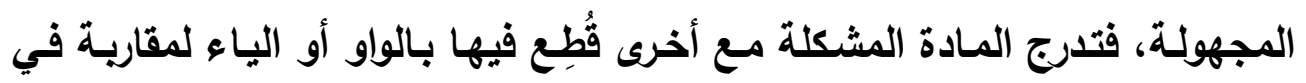
المعنى، وهو من طرائف استدلالات أبي علي وابن جني.

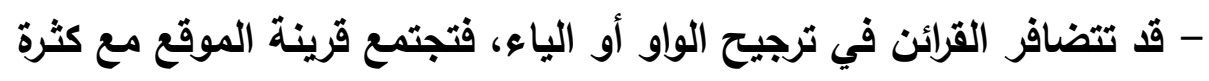

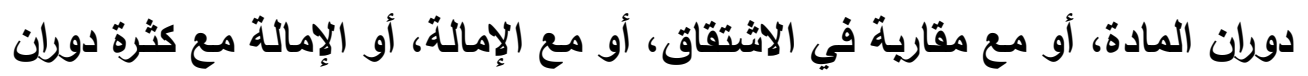
المادة، أو الحمل على النظير، ونحو ذلك.

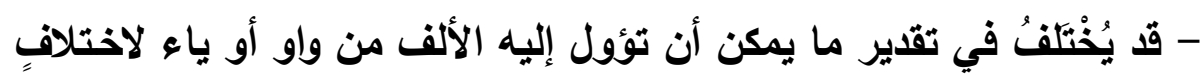

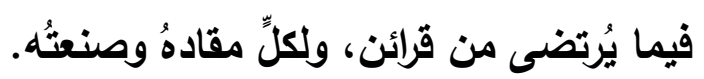


- إذا كانت الألف المجهولـة من الزوائد يُقضّى بأنها من الواو مـا لم تكن

$$
\text { رابعة فصاعدا. }
$$

- إذا كانت الألف رابعة فصاعدًا فهي من الياء قولا واحدًا، ويستوي في ذلتك

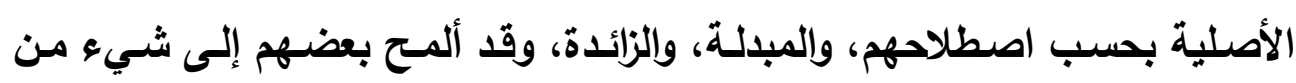
أسرار هذا الإجراء.

والحمد الله في البدء والختام ،6،6، 6

\section{مصادو البمث}


ا ـ الإبدال إلى الهمزة وأحرف العلة في ضوء كتاب سر صناعة الإعراب لابن

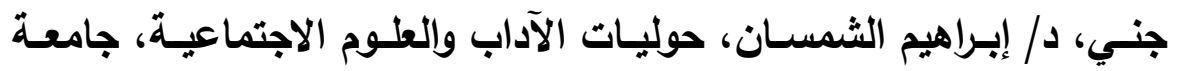

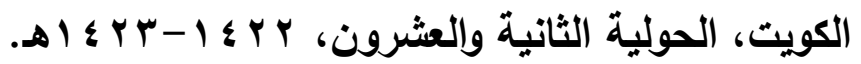
r. إبراز المعاني من حرز الأماني، أبو شامة، دار الكتب العلمية.

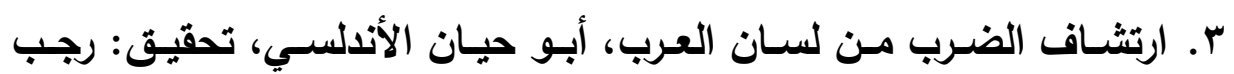

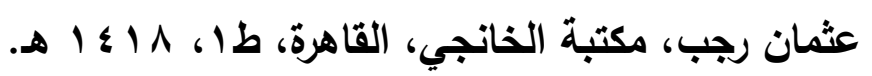

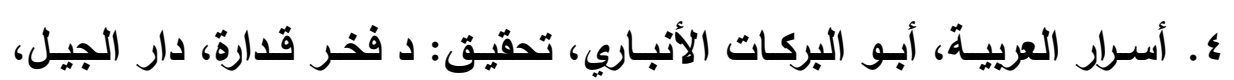

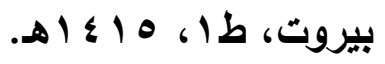
هـ الأصول في النحو، أبو بكر بن السراج، ت: عبد الحسين الفتلي، مؤسسة الرسالة، بيروت.

7. الأثباه والنظائر في النحو، جلال الدين السيوطي، ت: عبد الإله نبهان، مطبوعات مجمع اللغة العربية بامشث، 7 ، ـ أهـ الهـ V. الإغفال، أبو علي الفارسي، تحقيق الدكتور: عبدالله بن عمر الحاج، نشره

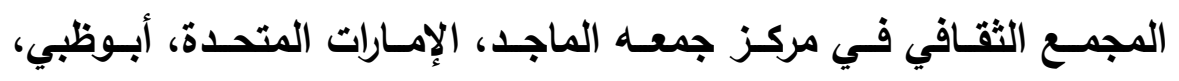
D $1 \& Y \varepsilon$

^. الإقناع في القراءات السبع، ابن البانش، ت: د / عبد المجيد قطامش، من

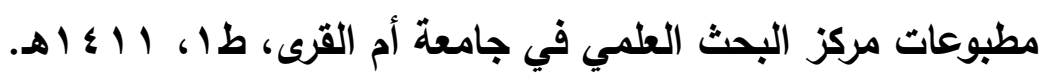
9. الإنصاف في مسائل الخلاف، أبو البركات الأنباري، تـ محمد محيي الدين

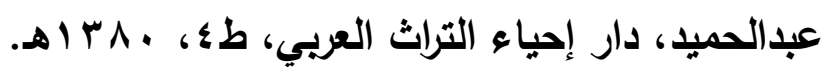


• 1. الإيضاح في شرح المفصل، ابن الحاجب، تحقيق: موسى بناي العليلي،

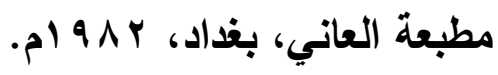

11. البارع في اللغة، أبو علي القالي، تحقيق: هشام الطعان، مكتبة النهضة، بذاد، ودار الحضارة، بيروت، طا، هV 9 اهـ الهـ

r I. البحر المحيط، أبو حيان الأندلسي، تحقيق: صدقي محمد جميل، دار

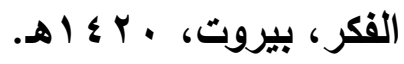

با 1. بصائر ذوي التمييز في لطائف الكتاب العزيز، مجد الدين الفيروزآبادي،

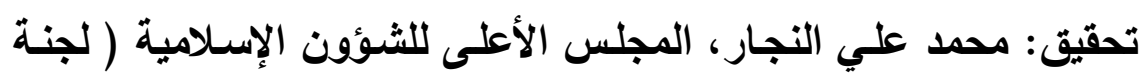

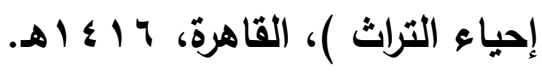

؛ ا. تاج العروس من جواهر القاموس، الزبيدي، تحقيق جماعة من الأسـاتذة،

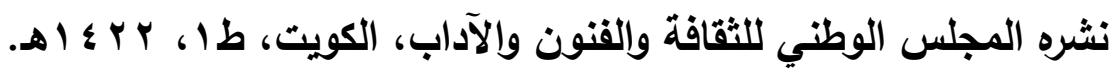
1 ـ تسهيل الفوائد وتكميل المقاصد، ابن مالك،، تحقيق: محمد كامل بركات،

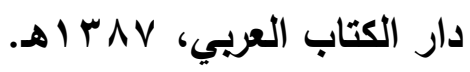

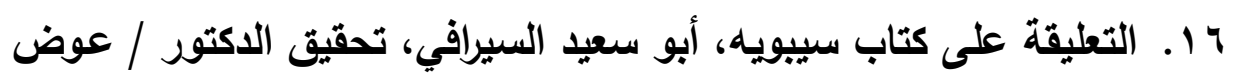

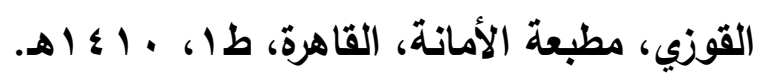

V V ا تفسير الرازي ( مفـاتيح الغيب )، فخر الدين الـرازي، دار إحياء التراث

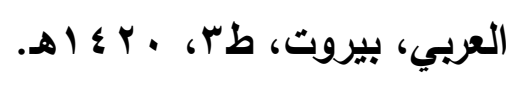

11. التمام في تفسير أشعار هذيل مما أغفله أبو سعيد السكري، ابن جني،

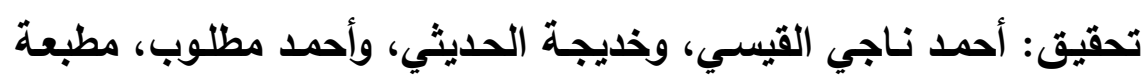

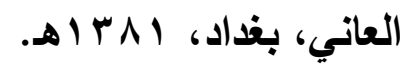


19. تمهيد القواعد ( شرح التسـهيل )، نـاظر الجيش، تحقيق مجموعة من

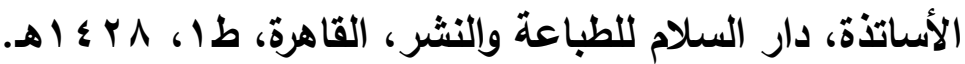

• . . التبيه على شرح مشكلات الحماسة، ابن جني، تحقيق الأستاذ الدكتور /

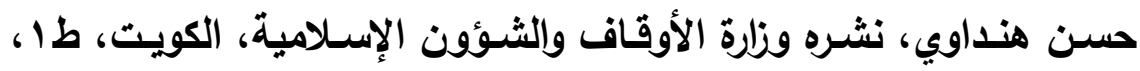

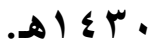

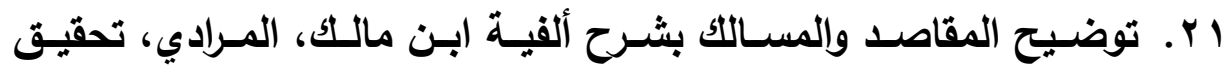

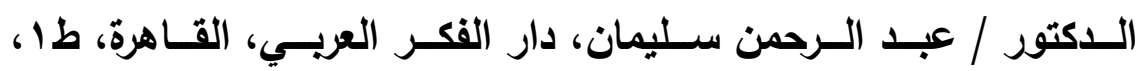
Dـ 1 \& Y

r r. تهذيب الألفاظ، ابن السكيت، تحقيق الدكتور / فخر الدين قباوة، مكتبة

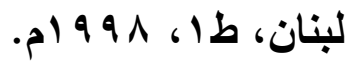

بr. تهذيب اللغة، أبو منصور الأزهري، تحقيق: محمد عوض مرعب، دار

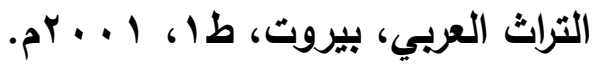

§ ؟. جمهرة اللغة، ابن دريد، تحقيق: رمزي منير بعلبكي، دار العلم للملايين،

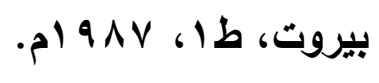

هץ. خزانـة الأدب ولب لبـاب لسـان العرب، البغدادي، تحقيق: عبد السـلام

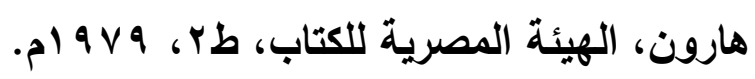
צr. الخصائص، ابن جني، تحقيق: محمد علي النجار، دار الهـى للطباعة

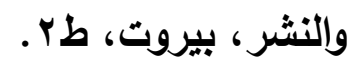

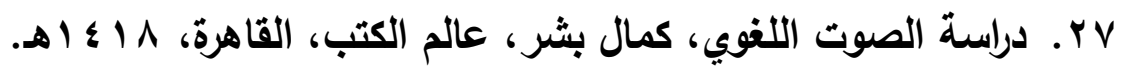
^ץ. دراسات في علم اللغة، كمال بشر، دار المعارف، القاهرة، ط9، 9191 ام. 


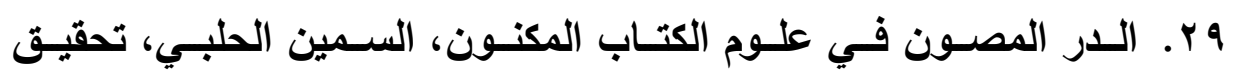

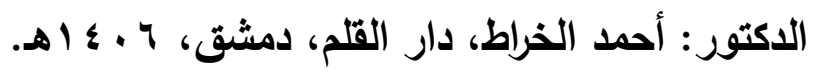

• r. ديوان أبي زبيد الطائي، تعقيق: نوري حمودي القيسي، مطبعة المعارف،

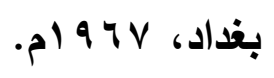

اس. ديوان الأعشى ( ميمون بن قيس )، شرح وتعليق: محمد محمد حسين،

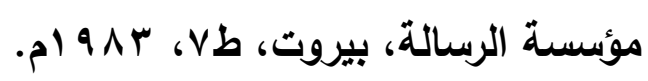

r r. ديـوان كثيـر عـزة، تحقيـق: إحســان عبـاس، دار الثقافـة، بيـروت، طا، $.019 \times 1$

r T. سـر صناعة الإعراب، ابن جنـي، تحقيق الدكتور: حسن هنداوي، دار

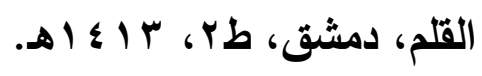

؟ ז. الثافية في علم التصريف، ابن الحاجب، تحقيق: حسن العثمان، المكتبة

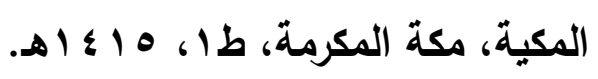

هr. شـرح أثسعار الهذليين، أبو سعيد السكري، تحقيق: عبد الستار فراج، مكتبة دار العروية، القاهرة.

צr. شـرح التسـهيل، ابن مالك،، تحقيق: د. عبد الرحمن السيد، ود. محمد

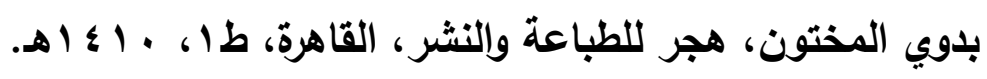

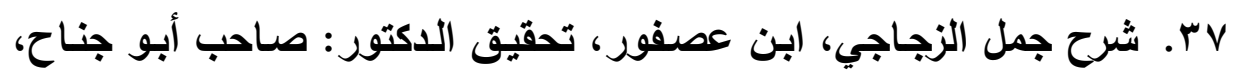

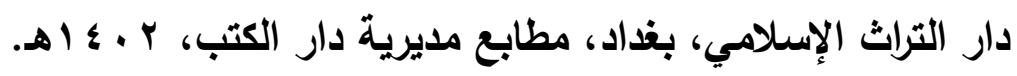

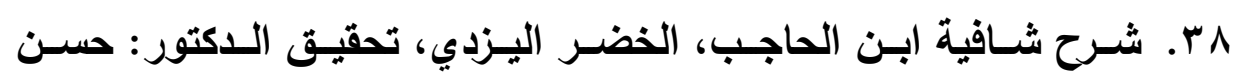

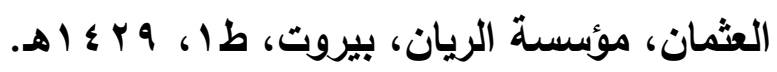


و r. شـرح شـافية ابـن الحاجب، الرضــي الأسـتراباذي، تحقيقق: محمــ نـور

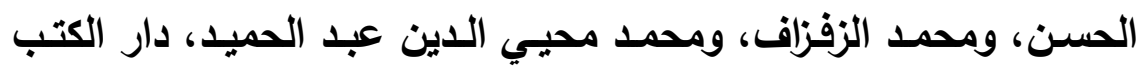

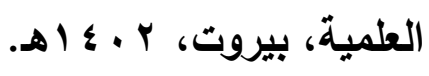

• ـ. شرح الكافية الثافية، ابن مالك، تحقيق الاكتور : عبد المنعم هريدي، دار

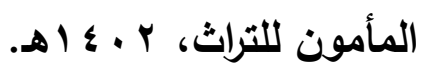

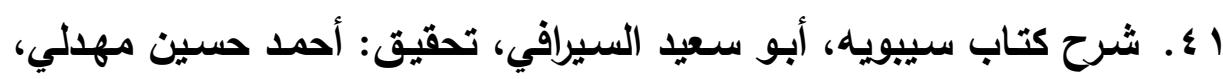

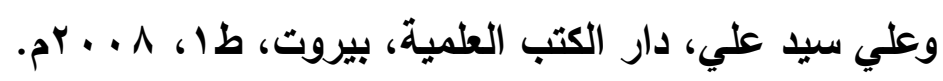

r ع. شرح المفصل، ابن يعيش، إدارة الطباعة المنيرية، مصر.

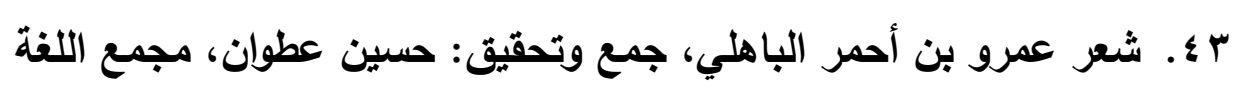
العربية بامشث.

§ ؛. شـس العلـوم ودواء كـلام العرب مـن الكلوم، نشـوان الحميري، تحقيق

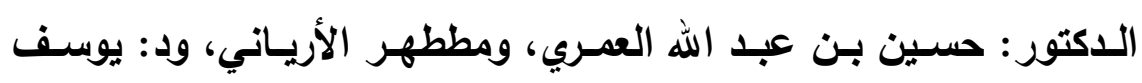

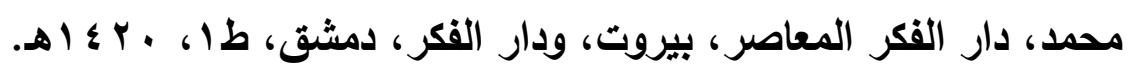
هـ ـ. الصحاح ( تاج اللفـة وصحاح العربيـة )، الجوهري، تحقيق: أحمد عبد

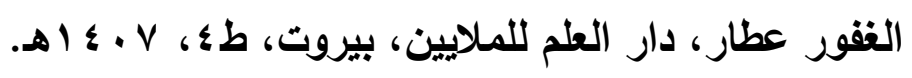
4 ؛. صناعة الكتاب، أبو جعفر النحاس، تحقيق الدكتور : بلر أحمد ضيف،

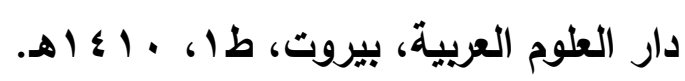

\& V . علل النحو، ابن الورلق، تحقيق: محمد جاسم الدرويش، مكتبة الرشد،

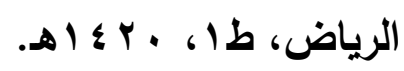


^ ـ ـ العين، الخليل بن أحمد، تحقيق الدكتور: مهـي المخزومس، والدكتور: إبراهيم السامرائي، دار مكتبة الهلال، بيروت.

9 ـ. القـاموس المحسيط، الفيروزبـادي، مؤسســة الرســالة للطباعـة وإلنشـر،

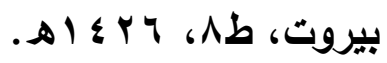
••. الكتاب، سيبويه، تحقيق: عبد السـلام هارون، مكتبة الخانجي، القاهرة، طץ، 1 . \& أه.

10. اللباب في علل البناء والإعراب، العكبري، تحقيق: غازي مختار طليمـات،

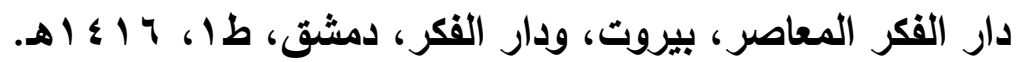

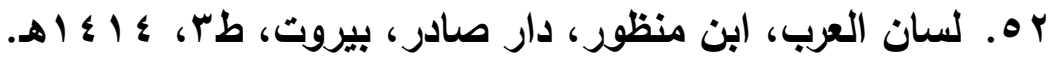
به. المحتسب في تبيين في وجوه شواذ القراءات، ابن جني، تحقيق: علي النجدي ناصف وزميليه، دار سزكين للطباعة والنشر، طץ، 7 ، ـ أهـ. ـه. المحكم والمحيط الأعظم، ابن سيده، تحقيق: عبد الحميد هنداوي، دار

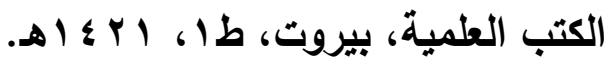

هـ ــ المختصـر في شـواذ القـراءات، ابـن خالويـه، نشـره برجستراسـر، مكتبـة

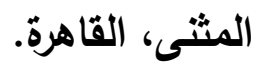

צه . المخصص، ابن سيده، تحقيق: خليل إبـراهيم جفـال، دار إحيـاء التراث

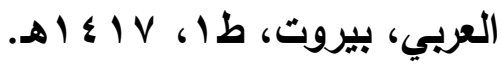

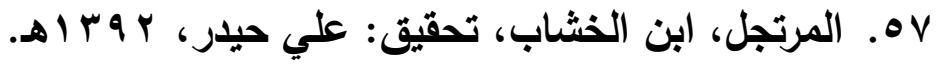
^هـ المسـائل البصريات، أبو علي الفارسـي، تحقيق الأستاذ الدكتور: محمد

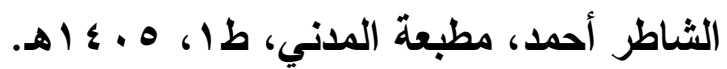


9ه. المسائل الشيرازيات، أبو علي الفارسي، تحقيق الدكتور: حسن هنداوي، كنوز إثبيليا للنشر والتوزيع، الرياض، طال، ؛ ؟ ؛ أهـ

• 7. مسند أحمد، تحقيق: شعيب الأرنؤوط، مؤسسة الرسالة، طا، ا ابع اهـ. ال7. معاني القرآن، الأخفش، تحقيق الدكتورة: هدى قراعة، مكتبة الخـانجي،

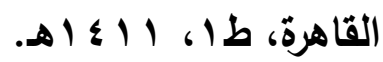

Y 7. معجم البلدان، ياقوت الحموي، دار صادر، بيروت، طץ، ه9 99 ام. ب.

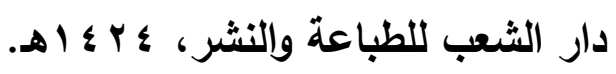

צ ا. المعرب من الكلام الأعجمي على حروف المعجم، أبو منصور الجواليقي، تحقيق الاكتور: ف عبد الرحيم، دار القلم، دمشق، طاه، ـ ـ ؛ اله. ه 7. المقاصد الشافية في شرح الخلاصة الكافية، أبو إسحاق الثـاطبي، حققه

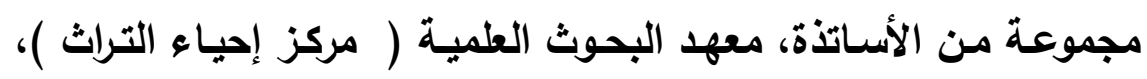

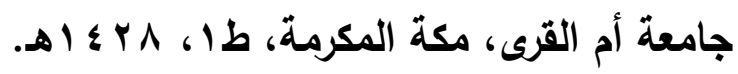
ד 7. المقتصد في شرح التكملة، عبد القاهر الجرجاني، تحقيق الدكتور: أحمد

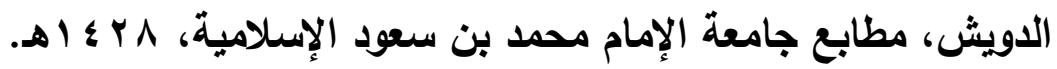
V. المقتضب، محمد بن يزيد المبرد، تحقيق: محمد عبد الخـالق عضيمة،

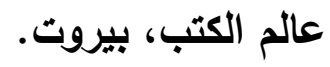

1 7. المقتضب في اسم المفعول، ابن جني، تحقيق الاكتور: أمين أحمد سـالم، دار أبو المجد للطباعة والنشر، القاهرة ب 99 ام. 
79. المقصور والممدود، ابن السكيت، تحقيق الدكتور: محمد سعيد، مطبعة الأمانة، مصر، طا، المور ولمدود ابن الهيت . . . . . . . . . . . . $.919 \ldots$

ا V. المقصـور والممـدود، الفراء، تحقيـق: عبـد الإلـه نبهـان، ومحمــ خير

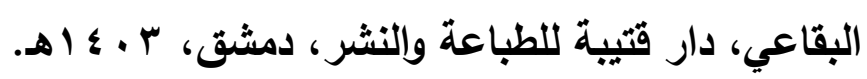
VY. الممتع في التصريف، ابن عصفور، تحقيق الدكتور: فخر الدين قباوة،

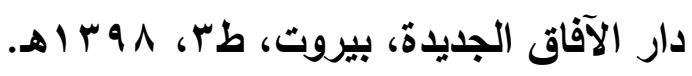

VT . المنجد في اللغة، أبو الحسن الهنائي ( كراع النمل )، تحقيق الدكتور:

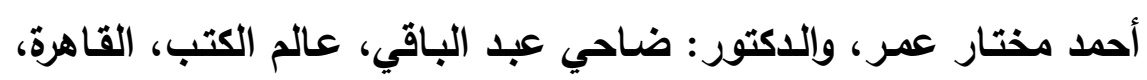

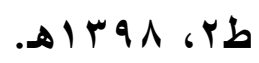

§ V. المنصف ( شـرح تصريف أبسي عثمـان المـازني )، ابـن جنـي، تحقيق:

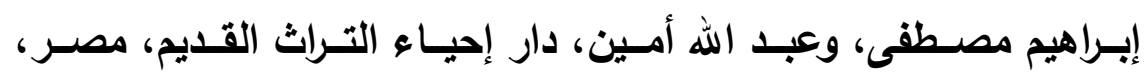

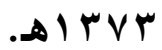

ه . . المنهج الصوتي للبنية العربية، الدكتور: عبد الصبور شـاهين، مؤسسة

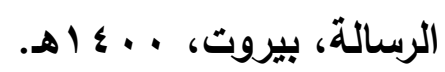

V7. النشر في القراءات العشر، ابن الجزري، تحقيق: علي محمد الضباع، المطبعة التجارية الكبرى، تصوير دار الكتب العلمية، بيروت.

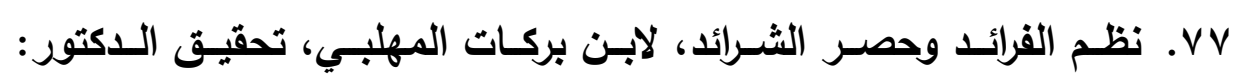

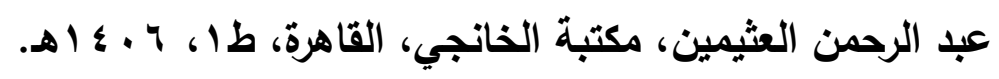


^^. النوادر في اللغة، أبو زيل، دار الكتاب العربي، طץ، Vج 9 ام. q. النهاية في غريب الحديث والأثر، ابن الأثير الجزري، تحقيق: طاهر أحمد الزاوي، ومحمد الطناحي، المكتبة العلمية، بيروت، 9 ج ب أهـ. 